\title{
Canadian Pride During the Vancouver 2010 Olympics
}

by

\author{
Marianne van Oosten
}

A thesis submitted to the Faculty of Graduate Studies and Research in partial fulfillment of the requirements for the degree of

Master of Journalism

Carleton University Ottawa, Canada 


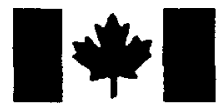

\author{
Library and Archives \\ Canada \\ Published Heritage \\ Branch \\ 395 Wellington Street \\ Ottawa ON K1A ON4 \\ Canada
}

Bibliotheque et

Archives Canada

Direction du

Patrimoine de l'édition

395, rue Wellington

Ottawa ON K1A ON4

Canada
Your file Votre référence
ISBN: 978-0-494-79601-6
Our file Notre référence
ISBN: 978-0-494-79601-6
NOTICE:

The author has granted a nonexclusive license allowing Library and Archives Canada to reproduce, publish, archive, preserve, conserve, communicate to the public by telecommunication or on the Internet, loan, distribute and sell theses worldwide, for commercial or noncommercial purposes, in microform, paper, electronic and/or any other formats.

The author retains copyright ownership and moral rights in this thesis. Neither the thesis nor substantial extracts from it may be printed or otherwise reproduced without the author's permission.
AVIS:

L'auteur a accordé une licence non exclusive permettant à la Bibliothèque et Archives Canada de reproduire, publier, archiver, sauvegarder, conserver, transmettre au public par télécommunication ou par l'Internet, prêter, distribuer et vendre des thèses partout dans le monde, à des fins commerciales ou autres, sur support microforme, papier, électronique et/ou autres formats.

L'auteur conserve la propriété du droit d'auteur et des droits moraux qui protège cette thèse. $\mathrm{Ni}$ la thèse ni des extraits substantiels de celle-ci ne doivent être imprimés ou autrement reproduits sans son autorisation.
In compliance with the Canadian Privacy Act some supporting forms may have been removed from this thesis.

While these forms may be included in the document page count, their removal does not represent any loss of content from the thesis.
Conformément à la loi canadienne sur la protection de la vie privée, quelques formulaires secondaires ont été enlevés de cette thèse.

Bien que ces formulaires aient inclus dans la pagination, il n'y aura aucun contenu manquant.

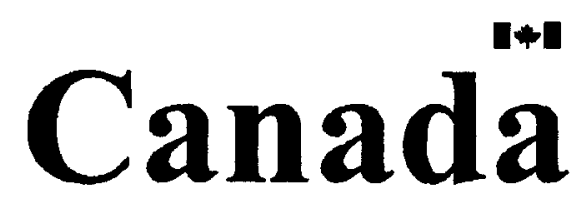




\section{Abstract}

Examines the planned and spontaneous factors that contributed to an increase in Canadian pride during the 2010 Vancouver Winter Olympics. Finds that the most effective factors for increasing pride included a vision to make the Olympics "Canada's Games", strong leadership, the cross-country torch relay, the red mittens campaign, a cultural program of events in Vancouver, the Own the Podium athlete and sport funding program with targeted medal counts, a strategic communications approach that encouraged public engagement, and a supportive relationship with national media. Conclusions made following a review of academic literature and public information, interviews, a media scan and public opinion research analysis. 


\section{Acknowledgements}

I would like to express my gratitude to my supervisor, Chris Waddell, whose encouragement, guidance, insight and support during the research, writing and defense of this thesis made this project a pleasure to work on and an inspiration. I am also grateful to Carleton University professor Paul Adams and CTV journalist Brian Williams for their guidance during the examination and defense of my thesis.

A special thank you to my family -- Jim, Nicole, Jacqueline and Rachel -- for your kind support and for encouraging me always.

Lastly, I offer my thanks to all of those who helped me in any respect during the completion of the project.

Marianne van Oosten 


\section{Table of Contents}

$\begin{array}{lr}\text { Introduction } & 1\end{array}$

$\begin{array}{ll}\text { Chapter \#1: Literature review } & 7\end{array}$

$\begin{array}{ll}\text { Chapter \#2: Planning for pride } & 25\end{array}$

Chapter \#3: Athlete success and pride $\quad 49$

$\begin{array}{ll}\text { Chapter \#4: Olympic Communications } & 70\end{array}$

$\begin{array}{ll}\text { Chapter \#5: Media Scan } & 91\end{array}$

Chapter \#6: Public Opinion Research 112

$\begin{array}{ll}\text { Conclusion } & 125\end{array}$

$\begin{array}{ll}\text { References } & 135\end{array}$ 


\section{Introduction}

It was a cold October day in Ottawa and the weather forecast called for snow. It was time to dig out the winter clothes, boots and woolen mittens. As I pulled out the boxes of winter clothing, I found last year's pair of red Olympic mittens and wondered if I should keep wearing them this year. They are warm, and I am a proud Canadian, so why not wear them again? I pulled them on and thought fondly of that time last year when I wore them faithfully all winter long.

These red Olympic mittens were just one of 15 pairs I bought before the 2010 Winter Olympic and Paralympic Games last year, held in Vancouver between February 12 to 28 (Olympics) and March 12 to 21 (Paralympics). I shopped for hours before I could find enough pairs, and then gave them to my three daughters, husband, sister, nieces, mother and even to visiting friends from New York, who were happy to wear our Canadian mittens while watching the Olympics from our living room television in Ottawa while cheering for their American athletes.

The mittens were one of the ways I celebrated the Olympics. I bought Olympic t-shirts and water bottles for everyone in my family for Christmas, baked red and white cupcakes for my daughter's school Olympic Day celebration, watched hours and hours of television coverage of the Games, read two newspapers a day for Olympic stories and photos, visited the Olympic web site to check on schedules, and spent two weeks being completely distracted by the latest competitions. I also had 
my picture taken with the Olympic torch relay flame when it came through Ottawa, and hosted a house full of excited friends to watch the final Canadian hockey game.

I have always watched the Olympics with interest, and have been a committed supporter of amateur sports with a special interest in ski racing. My daughters all ski raced for many years, and I therefore spent hundreds of hours volunteering, gate keeping at the side of the race course in minus 30 degree weather, driving kids to and from races, supervising a team while travelling out West, and attending dozens of meetings. I even considered volunteering for the Olympics but did not have the necessary qualifications and experience despite my hundreds of hours of volunteering at home and my various "officials" training sessions.

I would not typically consider myself an "Olympic junkie", but the 2010 Vancouver Olympics were different. I felt euphoric and excited during those two weeks of competition in 2010 , and found myself making television viewing of the Games a priority. I watched sports that I would never have been interested in before - like curling - and tried to learn everything I could about the athletes.

Once the Olympics were over, the Paralympics began with much less fanfare but still a great deal of attention and public interest. I took my family out to Whistler for a ski holiday during the Paralympics and was able to watch several of the events and experience the celebrations in the Whistler Square. The event had a completely different flavour, I was told by volunteers, but generated a quiet and strong sense of pride among Canadians. My strongest emotion was admiration as I watched disabled 
athletes throw themselves down icy ski slopes with significantly less control and more nerve than I saw from the Olympic athletes themselves.

When it all ended, I found myself mourning the passing of something great. I missed that feeling of excitement, pride and achievement of our athletes. In talking to friends, I found that my interest in the Olympics was a feeling shared by many. They agreed that this Olympic Games was some sort of milestone for Canada, and that we all wished we had been in Vancouver celebrating on the streets instead of watching the Games from the comfort of our homes.

Looking back on that time, I now wonder what exactly happened? What was different or special about these Olympics that got so many people involved, excited and proud to be Canadian? And would that feeling last for more than a few weeks after the competition ended?

This thesis will attempt to answer these questions. It will look at what factors contributed to the increase in Canadian pride during the Olympics - both planned and spontaneous - with a goal to finding a legacy or template for success that can be shared with others planning large events. While every Olympic Games is different and deals with different circumstances, there are many common elements that are shared by each event. In fact, the International Olympic Committee (IOC), which manages the Games and all elements of the Olympic movement, mandates that each Olympic Games follow very specific rules, guidelines and formulas. Finding out which factors worked in Vancouver and are replicable could greatly add to the lessons 
passed on from organizing committee to organizing committee, or could be adapted to the planning and hosting of different domestic events.

The purpose of this research is not just to satisfy my personal curiosity, but also to address my desire as a professional communicator to better understand what factors effectively produced pride and public engagement, and to satisfy my need as a Canadian taxpayer for the Games to be accountable to all Canadians. Hosting an Olympic event is expensive and requires resources to be provided by all levels of government and private industry. It also requires an investment of time, money and energy on the part of thousands of volunteers upon whom the Games rely.

According to the financial statements of the Vancouver Organizing Committee for the 2010 Olympic and Paralympic Games (VANOC), released in December of 2010, the final operating costs and revenues for the Games was $\$ 1.884$ billion, resulting in VANOC stating that is broke even and had no debt. In addition, $\$ 603$ million was spent on development of the Olympic venues. The federal government, the provincial government in British Columbia, the cities of Vancouver and Whistler, and private industry sponsors and partners, shared these costs. On its web site, the federal government states it invested $\$ 1.25$ billion in the Games, including $\$ 647$ million for essential federal services, like security and policing, health and safety, and technology; $\$ 290$ million for capital investments to build the sporting venues; $\$ 55$ million towards the Legacy Endowment Fund to provide funding for the ongoing maintenance and use of the Olympic facilities; $\$ 32$ million for the Paralympic Games 
operations; approximately $\$ 100$ million for the celebration sites, opening and closing ceremonies, and torch relays; and \$36 million for Aboriginal participation in the Games. This is a significant amount of money.

While there were many socio-economic impacts of the Olympics on Canada, this thesis focuses specifically on the impact of the 2010 Games on the pride of Canadians. It looks at the goals and planned activities which started before the 2003 bid when Vancouver was awarded the Games, to the efforts made by organizers to engage Canadians before the Games, to those events during the Games which affected the way Canadians felt about the event, their athletes and their country. This thesis looks at three sets of factors that contributed to national pride: 1 ) those factors that were planned by organizers, such as strategic communications, media relations and celebratory event planning; 2) those factors that were spontaneous, unpredictable or unplanned, including athletic results and stories, news and events; and 3) and the impact of the media on pride and the Canadian experience.

This thesis starts with a literature review of relevant research on the relationship between the Olympics and pride, nationalism, patriotism and national identity. As well as reviewing frameworks for identifying and comparing pride, and determining the impact of sport on a country's sense of pride, it reviews several case studies of Olympic Games and major sporting events hosted elsewhere, and the impact these had on the hosting country. It also looks at literature on national identity, specifically on what it means to be Canadian. 
This research demonstrates that one of the over-riding goals of hosting an Olympic Games is to increase national pride, and that an increase in pride does in fact happen. VANOC's mission statement, which is published extensively, stated that its mission was to "touch the soul of the nation and inspire the world by creating and delivering an extraordinary Olympic and Paralympic experience with lasting legacies."

There is little doubt that an increase in Canadian pride was clearly witnessed across Canada; this is not in dispute. This thesis therefore attempts to understand the change or increase in Canadian pride, and determine what factors caused the increase. Given that pride is a subjective matter and that it is difficult to measure, this research attempts to get a qualitative and quantitative snapshot of Canadian pride during the Olympics through an analysis of individual stories and interviews, a media scan of the coverage of two newspapers (the Vancouver Sun and the Globe and Mail) during the Olympics, and a review and analysis of public opinion research conducted during that period. It also attempts to address the role sport plays in national pride, why countries care about pride, and what pride means.

Through an understanding of the factors that increased Canadian pride during the 2010 Olympics, it is hoped that this will inform the planning of future events, both domestic and international, and contribute to the body of knowledge about national pride. 
Chapter \#1: Literature review

Major sporting events like the Olympic Games are usually assessed in terms of economic and social impacts. How much did they cost, what were the socioeconomic impacts and was the investment worth the time, effort and resources required to host the event? Only recently have scholars begun to examine the less tangible impacts of hosting the Olympic Games, such as the impact on civic pride and national identity. This chapter reviews scholarly publications that look at the relationship between the Olympic Games and national pride felt and expressed by the people living in the host nation. More specifically, this literature review addresses the ways in which the 2010 Vancouver Winter Olympics increased pride, reinforced national identity, and to what extent the Olympic Games were an effective "tool" for increasing pride.

The stated goal of the $\mathbf{2 0 1 0}$ Winter Olympics by the Vancouver Organizing Committee of Canada (VANOC), responsible for staging the Olympics in Canada in 2010, was "to touch the soul of the nation and inspire the world by creating and delivering an extraordinary Olympic and Paralympic experience with lasting legacies. The vision was to build a stronger Canada whose spirit is raised by its passion for sport, culture and sustainability" (VANOC web site). All the government, nongovernment and private partners involved in the 2010 Games supported this goal. 
The stated goals of the Canadian government were more specific and addressed the notion of increased pride more directly. Heritage Canada, the federal government department that oversees sports programming and spending across Canada, promotes the importance of sport to the Canadian identity, and argues that sport has many benefits to Canadians. On its web site, it stated, "sport is important to Canadians. It has the ability to engage citizens, build strong communities and improve the health of Canadians of all ages. Sport contributes to social cohesion and helps to surmount social barriers. It also contributes to national pride as Canadians celebrate the achievements of our athletes at Olympic and Paralympic Games." What is pride and "being Canadian"?

To understand the relationship between pride and the Olympics, it is important to first define pride and national identity as they are closely related and interdependent. The Oxford online dictionary defines pride simply as "a feeling of deep pleasure or satisfaction derived from one's own achievements, the achievements of one's close associates, or from qualities or possessions that are widely admired." Academics have slightly more complex definitions. Dutch researchers Ivo Van Hilvoorde, Agnes Elling and Ruud Stokvis suggest that pride is a complex notion which is related to identity, self-esteem and loyalty, as well as pleasure. For a nation, national pride is the same as self-respect for the individual. National pride can take many shapes, and could be identified on the basis of intensity of the emotions involved (Van Hilvoorde, Elling and Stokvis 89). 
M.D.R. Evans and Jonathan Kelley argued that national pride involves both admiration and stake holding - the feeling that one has some kind of share in an achievement or an admirable quality (303).

Will Kymlicka, a professor of political philosophy at Queen's University, attempted to answer questions about the nature of the Canadian identity in his article called "Being Canadian". Kymlicka stated that Canadians believe they are "good citizens of the world", are part of the West, are part of the "New World", and are non-American. Some of these perceptions were challenged in the article as Kymlicka provided examples of how Canadians' contribution to foreign aid is low compared to other countries, that Canada's commitment to international treaties (like the Kyoto climate change treaty) is "embarrassingly selfish and self-serving", and how we are not "kinder, gentler" than the US (364). Nevertheless, Kymlicka stated that it is important to emphasize that these qualities are seen as national character traits, part of the national identity, and an obligation of national citizenship. National identities are matters of perception, and it is clear that Canadians perceive themselves as good citizens of the world (359).

Others have noted that specific activities can enhance a sense of national identity. For example, Jason Morris believes that sport - in particular hockey - can help to create and reproduce national identity in Canada. Such cultural activities breed connections with others in a given nation. In this respect, hockey can be included as part of Canada's national identity. Hockey is "Canada's game" and its 
"national passion." Morris states that "hockey became the Krazy Glue of Canada's otherwise underdeveloped and shaky national identity," and that hockey helped promote and is part of Canada's national identity. Hockey is a "collective representation" about what being Canadian is, stated Morris, a political science professor at the University of British Columbia (48).

Similarly, Roman Horak and Georg Spitaler, professors at the University of Vienna in Austria, echoed the importance of sport to identity by describing the situation in Austria, where a new Austrian national identity emerged in the last few decades resulting from increased public interest and participation in soccer and alpine skiing. The athletes of both sports were promoted as national role models, and politicians used the sports as publicity instruments to promote their own social and economic goals in an effort to get elected or re-elected. As the popularity of the two sports increased in Austria, they contributed to the emergence of a new national identity, and were recognized by politicians as important instruments in the shaping of an Austrian identity (1507).

Grant Jarvie, of the Department of Sports Studies at the University of Stirling, argued that many of the traditional things that helped forge a sense of belonging in the past-countries with relatively homogenous populations; sports teams of homegrown nationals; well-established local communities; and allegiance to local teams, history, and tradition-are all challenged by globalization. Jarvie noted that having some idea of who we are helps us to define how we ought to live and conduct our 
daily affairs. Sport has helped and will continue to help different groups know themselves (544).

However, Canada's notion of national identity - or what "being Canadian" means - is constantly being challenged by globalization and internationalism. According to New Zealand scholar Steven Jackson, the Canadian crisis of identity as constitutive of, and constituted by, the identity politics of Donovan Bailey and Ben Johnson supports this contention. Ben Johnson was a Canadian sprinter best known for his gold medal in the 100-metre sprint at the 1988 Olympics. After a positive drug test for anabolic steroids, Johnson was stripped of his medal, and this started a 'year of crisis of Canadian identity'. Jackson noted that the anticipation of Johnson's Olympic triumph provided a rallying point for Canadians on several fronts, but his medal loss had an even greater impact. As Jackson stated, "The late Canadian actor/comedian John Candy effectively characterized the identity politics of Ben Johnson stating that: 'At first, he was closely related to Sir John A. Macdonald, the first prime minister of Canada. The moment he was disqualified, he came from Jamaica' (US Magazine, 1989: 6). Both Johnson and Bailey had been referred to in the media as "Jamaican-born Canadians". Despite winning two gold medals and setting a world record in the 100-metre event at the 1996 Olympics, Bailey retired from sport in 2001 under less than ideal circumstances fighting age, injury and a loss of popularity due to the haunting legacy of Ben Johnson's fall from grace in 1988 (Jackson 121). With an increasing number of athletes competing for countries that 
are not their countries of origin, there is a struggle over nationhood, citizenship and the meaning, basis and authenticity of national identity within and outside sport (Jackson 138).

\section{Benefits of national pride}

Given that a strategic goal of the Olympics is to increase national pride within the host nation, it is interesting to review what scholars have to say about the effects and benefits of pride to a country. Sociologists Louise Heslop, John Nadeau and Norm O'Reilly argued that the successful hosting of the Olympics could create a tremendous sense of pride among residents of the host country. In addition, working together to create the sporting and cultural venues and activities can develop nationalistic cohesion, as well as a sense of purpose and coalescence around meeting the collective goals. National governments can garner tremendous positive image enhancement just from being associated with Olympic success (424).

University of British Columbia psychology professors Jessica Tracy, Azim Shariff and Joey Cheng explored social and psychological aspects of pride to explain what effect and benefits it has on society. They stated that pride likely evolved to serve the function of enhancing social status, because the pride experience motivates individuals to strive for achievements in socially valued domains. Pride feelings are pleasurable and thus reinforce the value of making an individual feel good about themselves. These reinforcing properties of pride then motivate individuals to seek future achievements so that individuals strive to develop an identity that coheres 
with social norms (168).

Similarly, Panos Karkatsoulis, Nikos Michalopoulos and Vasso Moustakatou, researchers working in Greece and Brussels, wrote about the connection between national pride and identity expressed at a major sporting event like the Olympic Games and the effect this has on volunteers. This article looked at national identity as a motivation factor for better performance in the public service, with a focus on the relationship between volunteers working at the Athens Olympic Games and their level of pride and commitment. The authors stated that there was a long-standing relationship between sports (especially the Olympic Games) and "national pride", and that "pride strongly motivates people to work" (585).

Sharon Kemp, from the University of Western Sydney (Australia), wrote about what motivated volunteers at the 2000 Summer Olympics in Sydney Australia and the 1994 Winter Olympics in Lillehammer, Norway. She described the benefits of volunteering at an Olympic Games, and the relationship between Olympic volunteerism and increased pride. Kemp stated that volunteers were motivated to participate by the opportunity to be a part of a unique event and the celebratory atmosphere, a sense of feeling valued, increased feelings of self-worth, and a new sense of confidence and cooperation (115).

\section{Olympics as a tool for pride promotion}

Alan Bairner, a lecturer with Ireland's University of Ulster, stated that the close relationship between nationalism and sport was an acknowledged fact, and few 
activities today provide better or more frequent opportunities than sport for individuals to publicly express their commitment to a particular nation, whether as participants or, more commonly, as spectators. As a consequence, the close relationship that exists between nationalism and sport has been increasingly recognized, with the most popular form of nationalist behaviour in many countries being masses of people becoming highly emotional in support of their national sport team (314).

John Hunter, a professor of sport sciences at Brunel University in the U.K., stated that the impact of sport on nation and identity in a commercialized, increasingly global era, may be one of the most powerful factors to influence the shaping, indeed reshaping, of identities in the twenty-first century. However, he noted that further research was needed on how sport shaped national identity because there were dangers arising from the interface of sport and identity which could lead to "reshaping" of national identity which could have a negative effect on gender equality, for example (409).

In an article about the relationship between nationalism in South Korean media representations of the 1968, 1984 and 2000 Olympics, University of Singapore researcher Younghan Cho stated that "Sporting events, particularly as represented by the media, are crucial to a society's construction of an imagined community as well as nationalism. On the other hand, sport is one of the major venues in which people experience national competence and prestige. By generalizing the victory of a 
national athlete or a national team to national success, sporting events become very useful tools for invoking a passionate nationalism" (360). He also stated that sporting nationalism contributes both to encouraging national unity and belonging, and fostering a sense of national competence and prestige among people.

Pieter Labuschagne argued that sport was inseparable from nationalism and can form a powerful tool in the hands of politicians. Yet there was also a perception that sport had an inflated status as social unifier - that it was nothing more than 'ninety minute patriotism '. The author, a professor at the University of South Africa, investigated the role of sport as a nation builder, with specific reference to South Africa as a divided and fragmented developing country. He argued that the South African government's initiative to stage the 2010 World Cup of soccer was underpinned by deeper socio-political motives, and the decision to stage these events must be seen in the context of South Africa as a developing nation. Labuschagne noted that staging a major sporting event should have positive benefits - politically, socially, economically and most importantly, as a means of promoting nation building (13).

Canadian sociologists Graham Knight, Margaret MacNeill and Peter Donnelly wrote about the opposite of Olympic pride - Olympic disappointment - and how Canadians reacted during and after the 2000 Olympics, when their expectations of medals were not met. In this article, the authors compared Canada's response to failure with that of New Zealand. New Zealand's reaction to Olympic disappointment 
was dominated by claims that athletes lacked a competitive attitude and the 'will to win', and this was generalized to New Zealand society and the educational system in particular as indicative of a broader loss of moral values. The Canadian response, on the other hand, was framed in more cognitively oriented terms. Athlete blaming was quickly dismissed as misplaced, and attention was directed to the lack of government funding and organizational problems in the 'sport system' as the principal reasons for disappointing results. Despite these differences in response, extensive media coverage of the Games and the athletes' lack of success in both countries underlined the important role that disappointment plays as a reaction to the problematic relationship between expectations, values, and emotions (48).

Finnish sociologist Paavo Seppanen stated that nationalism had never been foreign to the Olympics. While Olympic advocates had declared the creed of universal participation for the betterment of mankind, the countries of the world had interpreted the participation in the Games as an opportunity to express national feelings and national identification. The Games had been used not so much for international fair play, peace and understanding as for national self-interest and pride (116).

University of British Columbia researchers Katherine McCallum, Amy Spencer and Elvin Wyly agreed that an essential premise of the Olympic movement-in its ancient as well as modern incarnations-was that sport had the potential to serve as a unifying force among different peoples. The images and symbols of First Nations 
cultures had long been mobilized as part of Canadian tourist-promotion strategies, and were an important contributor to the successful bid by VANOC to win the 2010 Olympics (36).

John Hargreaves, a professor with the University of Brighton in England, argued that the organizational structure of the Olympics Games events itself facilitated and encouraged the promotion of national identity and pride. Since 1912, athletes have only been able to compete as representatives of a nation, not individually, and the nation became the participating unit in the Games. Hargreaves noted that the national element was strongly present from the start when modern Olympic founder Pierre De Coubertin needed the backing of prestigious, national figures for support, whose status and participation reinforced the nationalist nature of the event (125). Hargreaves also noted that the Olympic Games is a highly dramatic spectacle because it features a contest, and these types of contests generate intense excitement and tension because the athletes tend to be idolized and identified with, and the outcome is inherently unpredictable. Because the Olympics are in effect a specialized form of popular theatre, they have the power to attract people, providing opportunities for many people to identify with admired performers/athletes as they attempt to find meaning in the ritual, drama and spectacle. These meanings are constructed by audiences out of the cultural material at their disposal, and by virtue of their membership of national cultures, they are predisposed to view the Games through a nation-tinged lens (127). 


\section{Expressing pride at the Olympics}

If the Olympics can be used as a tool for increasing national pride, how was this expressed in Vancouver and how can it be measured? Public opinion polls, analysis of media coverage, and a review of the stories and narratives of the Olympic experience will do much to determine if there has been a shift or change in national sentiment resulting from the Olympics. All of these instruments will be examined in further chapters of this thesis.

The Olympics provide ample opportunities for people to display their pride through the frequent use of national symbols, such as the national flag and the national anthem. These symbols efficiently enable people to feel attachment both to their national team and to their country, just as identification of major rivals also makes it possible for people to demarcate national territory and imagine national boundaries (Cho 360 ).

Gerald Gems echoed the importance of Olympic symbols to national pride in examining sport and national pride in Puerto Rico. Gems, a professor at North Central College in Illinois, acknowledged the symbolic importance of the Olympic opening ceremonies, stating that it does not matter whether a country wins or loses, but it is the Olympic procession at the start of the Games that is important. He argued that sport had become the most important single issue with respect to national identity, and that athletic stars and international competitions with a separate flag reinforced a sense of common identity, pride, and esteem (117). 
Hargreaves argued that the Olympic opening ceremony has become the occasion for the host nation to put on a performance incorporating elements of its national culture through which it projects an image of itself to the whole world. He stated that the most powerful signifier of nationalism is the Olympic award ceremony, where a gold medal is placed around the victor's neck, the national flag is raised, and the victor turns to it as the national anthem is played, then waves to the crowd where co-nationals applaud vociferously sporting the national symbols. There are few more powerful displays of national triumphalism (126).

Similarly, Theresa Housel, a professor at Hope College in the U.S., examined how the 2000 Sydney Olympic Games opening ceremony presented images of a unified national identity, however media coverage of the event commented on the explicit staging of the ceremony to project a unified image that would increase national pride. Housel argued that the result was the opposite. The opening ceremony was viewed as a public relations exercise, and the Australian newspaper coverage of the Olympics highlighted a fragmented Australian identity and nation (457).

\section{Does winning matter?}

Van Hilvoorde, Elling and Stokvis argued that elite sport was often regarded as one of the main vehicles for articulating national pride and stimulating national cohesion, in particular if there is success in elite sport. The authors stated that in most modern countries, elite sport is often used to construct and maintain an idea of 
national unity, and that sports offer many unique and different ways to articulate national identities, such as through rituals and ceremonies. The authors stated that one of the most popular Olympic activities was the overall comparison of nations on the Olympic medal index. A medal index may be a good instrument for sport policy, but the authors questioned whether it was effective at arousing national emotions and increasing national pride (Van Hilvoorde, Elling and Stokvis, 2010, p. 87). The interest in medal indexes is fed by the expected ranking that develops into common knowledge. Each country has its own range of expected rankings, related to variables, such as population and wealth, as well as performances in the past (93).

According to Van Hilvoorde, Elling and Stokvis, sport events and sport success could be related to national pride in several ways. The authors described the notion of sport success as a direct mirror of national identity, showing us who we are, what we look like, what we have accomplished, and whether we should celebrate ourselves or not. Stories about athletes' experiences at the Olympics can function as a direct mirror of national identity, and can strengthen national stereotypes presented in the media. Even if national identity we see in the mirror is fiction, or an "invented tradition", the very fact that it has been used to define the situation makes it real. However, contrary to the notion that national pride is a mirror is the 'bucket-notion' of pride. This view is built around the notion that a nation's pride is like a bucket that can be filled or fuelled by winning more medals - therefore, the more medals, the more pride - but that the bucket can also be emptied or 
experience a "leak" if the country doesn't win enough medals or other circumstances cause the bucket to empty (99).

\section{Influence of the media on Canadian pride in the Olympics}

Andrew Billings and James Angelini, both from Indiana University, argued that there are two theories that come into play regarding the media's influence on Canadian pride through reporting of the Olympics: agenda setting and framing. According to the principles of agenda setting, the media covering the Olympics may not have direct influence on what viewers or readers think, but the media can be successful at determining what topics we think about regarding the Olympics. Once the media uses agenda setting, it can then use news framing to influence what viewers or readers believe. Thus, the agenda is set through a clock-time mechanism (determining what sports and athletes are shown), with the athletes that receive clock-time being framed through the language that accompanies sports talk narratives.

Billings and Angelini also argued that there were three functions of media frames that are relevant to sportscaster talk: selection, emphasis and exclusion. For instance, a sportscaster selects a line of attribution, such as that the performance was superior because of the athlete's concentration, determines the degree to which this explanation should be emphasized, and makes this decision to the exclusion of other alternatives, such as the performance being superior because of the athlete's experience (364). 
Sports journalists and sport authorities create a variety of narratives that offer different explanatory interpretative frames, which provide accounts of causes and effects. Explanatory frames ('why did we lose/win?') can be extended from the individual athlete to the coaches, sport institutions, training facilities, funding or even to even broader categories, such as 'the mentality' or 'vitality' of a country. Discourses on the number of medals expected to be won generate 'narratives of expectancy', then are objectified by the scientific research that indicates relations between sport funding and the number of medals that a country is capable of winning (Van Hilvoorde, Elling and Stokvis 93).

Besides the medals themselves, this 'narrative of expectancy' also has the potential to develop into a mirror of national identity. This is what we, as a nation, are worth. This is what we should win; otherwise we fail. Failing to meet the expectations in many cases instigates a narrative of blame. Who is to blame varies and is closely related to the ways that expectations have been embedded prior to each competition. Whatever the final ranking on a medal index is, each narrative (of expectancy) that is focused on the medal index more or less contributes to the experience of national identity (Van Hilvoorde, Elling and Stokvis (93).

Hargreaves stated that the meaning of the nation is also constructed in relation to a chain of powerful economic interests. At stake is access to a vast audience, with which advertisers and sponsors will pay immense sums of money to communicate. Consequently, television rights are a major source of financial support for the Games, 
and the latter are increasingly subject to the demands of the television networks in their efforts to capture the maximum audience and deliver it to the commercial interests (127).

\section{Summary}

As was evident in the literature review, scholars largely agreed that elite sport can enhance national pride, that large sporting events like the Olympics can help to create and reproduce a sense of national identity, and that sport has the potential to serve as a unifying force among different peoples. Elite sport was regarded by several researchers as one of the main vehicles for articulating national pride and stimulating national cohesion, in particular if there was success in elite sport.

Scholars also agreed that the successful hosting of the Olympics could create a tremendous sense of pride among athletes, volunteers, Canadian residents, politicians and the media of the host country. It was agreed that staging the Olympics had positive benefits for the host country, including politically, socially, economically and as a means of promoting nation building.

From a theoretical perspective, these views were used to help determine the extent to which national pride was enhanced among Canadians during the Vancouver 2010 Olympic Games, what factors helped to increase pride, and whether the Vancouver Olympics united Canada in a way that was expected by scholars, or in a way that was unexpected. Several of the articles dealing with Canada's notion of national identity - or what "being Canadian" means - also helped inform the 
discussion and analysis in this thesis regarding how the Olympics affected Canada's particular sense of national pride, identity and belonging.

The following chapters will use the views, arguments and information presented by scholars in the literature review to examine the 2010 Vancouver Olympics, and use it as a case study for determining what factors lead to an increase in Canadian pride. 


\section{Chapter \#2: Planning for pride}

Planning for an Olympic Games is not a quick or simple task. It usually takes a minimum of seven years from the time a city is awarded the Games until the event occurs, plus years in advance of that for preparation and negotiation with private and public organizations to submit an Olympic bid. It also requires the work of a large team of dedicated people who are willing and able to articulate a vision for what they hope to achieve, develop the plans, find the resources, build the facilities, make the necessary connections, and then run every aspect of the event. And it takes billions of dollars.

VANOC developed a number of strategic plans to help prepare for the 2010 Games, including an all-encompassing Business Plan and Games Budget (May 2007) which consisted of plans, schedules and budgets for sport and venue management, Games operations, risk management, procurement, human resources, contracts and agreements, cultural activities, health services, communications, sustainability, official languages, evaluation, and legacies. Each of these plans evolved as the Games approached, and changed to respond to the changing economic reality of an economic downturn just before the Games. The plans also adapted to new and better ideas brought forth by those involved and by changing circumstances.

No matter how much planning is done and how airtight those plans are, there are always a multitude of factors that can impact or influence the outcome of the 
event that are entirely unpredictable - such as changes in the economy, poor weather, lack of athletic results, personal tragedies, public protests, or any number of social, political or environmental factors. During the 2010 Games, day-to-day event management plans changed to respond to several crises that plagued the 2010 Games early in the competition, including the death of Georgian luger Nodar Kumaritashvili, the poor weather and lack of snow on Cypress Mountain, the failure of one of the Olympic arms to erect during the Opening ceremonies, and the public dissatisfaction with the fencing off of the Olympic flame.

While VANOC's various plans addressed every aspect of the Games that could be planned, they also tried to plan specifically and intentionally for Canadians to feel proud. Implicit in almost every plan was a sub-goal to increase Canadian pride. Given that its goal was to make the 2010 Olympics "Canada's Games" - not just Vancouver's Games or British Columbia's Games - and that it aimed to "touch the soul of the nation and inspire the world by creating and delivering an extraordinary Olympic and Paralympic experience with lasting legacies," VANOC had a challenge to meet. It was clear that the 2010 Olympics were intended to do much more than celebrate fair play, peace and understanding. The Vancouver Games were intended to be about pride, spirit, and a successful experience for all Canadians.

Ann Duffy, spokesperson for VANOC's sustainability program, further defined the relationship between the Olympics and pride: "It is a given that hosting the Olympic Games inherently enhances pride. The Olympics are designed to enhance 
pride, and there is an understanding among all involved - the IOC, VANOC, governments and other organizations participating - that hosting the Games will result in pride." As stated in its business plan, VANOC "projects that national pride and accomplishment of what a city, region and country can do when people come together to celebrate sport, culture and sustainability will result from hosting the Games." (VANOC Business Plan and Games Budget 35).

How does an organization plan for pride, and what is the formula that successfully results in an increased sense of national pride during the Olympics? The following chapter will attempt to look at what factors contributed to pride, whether specifically designed by VANOC to increase pride, or those spontaneous, unplanned and unpredictable factors that had the same effect. Subsequent chapters will deal with the link between athlete success and pride, and the role of the media during the Olympics.

Planning for pride at the Olympics is even more complicated than a normal sporting event because it involves many very specific requirements and deadlines, and a steep history of expectations and processes, all overseen diligently by the IOC. The modern Olympic Games have been in existence for more than 100 years, since Pierre de Coubertin revived the Games in 1894, and the first modern Games were staged in Greece in 1896. There is considerable experience, knowledge and understanding about what an Olympic Games event sets out to accomplish and what 
it can achieve because this is specified in the IOC's Olympic Charter and clearly spelled out in the mission and goals of the Olympic movement.

The IOC Olympic Charter is a set of fundamental principles, rules and bylaws adopted by the International Olympic Committee (IOC), which govern the organization, action and operation of the Olympic movement and set forth the conditions for the celebration of the Olympic Games (11). The Charter is the basic constitutional instrument used to govern and enforce the principles and values of Olympism, and defines the rights and obligations of the IOC, international federations and national Olympic committees, and the organizing committee of the Olympic Games, such as VANOC.

The Olympic Charter also outlines the rules for the celebration, organization and administration of the Olympic Games, including rules about the application, evaluation and election of the host city. Once elected, the successful organizing committee must abide by all the IOC rules, which have as much to do with keeping the Olympic spirit alive as they do about the details of administration. The $1 O C$ web site defines "Olympism" as having three Olympic values: excellence, friendship and respect, with a goal of building a better world through sport.

Eric Rothenbuler, a professor at the University of lowa, stated that the IOC has always jealously guarded the Olympic symbols, calendar, and rituals and thereby its control over the Games and what they achieve. For example, the Games are framed by opening and closing ceremonies, marking off a certain time and place as a special 
community, constituted and regulated by special rules. The progress of the Games is marked by hymns, flags, flames, rings, stars, and wreaths (65).

Nationalism has never been foreign to the Olympics, argued Finnish sociologist Paavo Seppanen. While Olympic advocates have declared the creed of universal participation for the betterment of mankind, the countries of the world have interpreted the participation in the Games as an opportunity to express national feelings and national identification. The ideals of the Games have not been rejected but they have been translated into a language of entirely different practical use. The Games have been utilized not so much for international fair play, peace and understanding as for national self-interest and pride (118).

\section{Olympic bidding process}

It all started with the Olympic bidding process. In 1998, the Canadian Olympic Committee (COC) selected Vancouver to present Canada's bid for the 2010 Winter Games. Over a five-year period, the Vancouver 2010 Bid Corporation developed a Games delivery plan with a vision of creating sustainable legacies for athletes, sport development, host communities and the Olympic and Paralympic Movements. On July 2, 2003, members of the IOC selected Vancouver as the host city of the 2010 Winter Games.

John Furlong, the CEO of VANOC from 2004 until the Games ended, stated that "we needed to try to turn the Games into a nation-building event and this was as much a part of the business plan for the Games as it was trying to give Canada a 
moment in time, a seminal moment for the country. "Prior to his appointment at VANOC in 2004, Furlong was the President and Chief Operating Officer for the Vancouver $2010 \mathrm{Bid}$, and had been involved with the COC and various BC Games organizations before this.

Like every organizing committee before it, VANOC had to develop a compelling bid and comprehensive plan for winning the bid. There were many technical requirements that had to be fulfilled by the bid as mandated by the IOC, including plans and budgets for everything from sporting and award venues, sport development, the Olympic Village, medical and health services, security, accommodation, transportation, communications and media services, Olympism and cultural plans, environmental protection, finance, marketing, and legal aspects (Vancouver 2010 Bid Book, 2002).

While VANOC's bid addressed the IOC's needs and criteria, it also contained a plan for how to inspire Canadians, build pride, and leave a legacy of Olympism. Implied in each element of the bid was the recognition that the hosting of the Games would result in national pride for the host country and would establish a legacy for the country for the future.

In the bid book submitted to the $1 O C$ by the Vancouver 2010 Bid Corporation in 2002, the links between the Olympic ideals and Canada were clearly made: "Our opportunity is to engage Canadians at every level of our society as proponents of the Olympic ideals, as carriers of its message and as examples of its values... Canada's 
love of and success in winter sport will provide a significant emotional backdrop to our Games and allow the intense participatory pride of all Canadians to infuse our Games with competitive excitement and compelling messages and imagery from across our great land." (112).

In many ways, hosting the Olympics is a matter of using the same recipe with mostly the same ingredients, but it's how the cake is baked that differentiates each set of Olympics. Vancouver's challenge was no different. It had to meet all the traditional IOC requirements for a host city, and had to design a Games event that would appeal to Canadians, who were their primary audience for the Games.

\section{Packaging the Olympic vision}

Appealing to Canadians meant designing an event that not only pleased Canadians and enticed them to watch it, attend it and volunteer for it, but also that reflected what Canadians thought about themselves. As was presented in the bid book, the Vancouver bid organization packaged the Vancouver Olympics as a product not just an event. While the event being planned was a complex sporting event, the Olympic product that was being packaged and proposed was a distinctly Canadian sense of pride and participation. The product was also packaged as a brand or image which included a graphic identity using specific colours and shapes, the selection of an emblem - the llanaaq, a modern version of the Inukshuk and the Inuktitut word for friend - and a complete range of Olympic materials, events, products and ceremonies designed to create an inspiring image. 
Maureen Douglas, VANOC's Director of Community Relations and the Director of Communications for the Whistler venue, said, "VANOC's bid contained the traits we wanted represented on the world stage, such as the involvement of the four host First Nations. We had to define who was Canada? Honesty, transparency, integrity all those things were really important to us."

While the Vancouver Olympics was designed to mirror this national identityshowing Canadians and the world that we are a nation of people with honesty, transparency and integrity - it also projected a new Canada which was populated with happy, spirited, fun-loving, successful people who excelled at sport. Even if the national identity we projected in the Olympic bid was a partially invented identity, the very fact that it had been used to define the situation made it real (Van Hilvoorde, Elling and Stokvis 99).

VANOC spokesperson Ann Duffy argued that pride doesn't just happen. "In order to win pride, you need to plan for pride and develop a number of "tools" that will help you encourage and facilitate pride to grow. You have to talk to Canadians to determine what it is you want people to be proud of, what Canada is obligated to do by the IOC and the Olympic Charter, and how you can plan, deliver and execute the venues in order to deliver the Games."

Some of the more successful "tools" used by VANOC for planning for pride included its vision and leadership, the torch relay, the red mittens campaign, the cultural events held on the streets of Vancouver, the volunteers, the 
communications, and the Own The Podium program. There were many other programs and activities that helped achieve success at the Games and were important to their successful operation, however they do not appear to have had a direct impact on pride in the same way.

\section{Vision and leadership}

AS CEO of VANOC, John Furlong's leadership was touted by many as one of the reasons for increased public support and patriotism. Several people - including both those who worked on the Games and journalists - echoed the opinion that one of the reasons for the success of the 2010 Olympics was the vision, dedication and leadership of Furlong. His vision of making the 2010 Olympics "Canada's Games" to be shared by people across Canada was the over-riding mission of every VANOC activity, and it became an instrumental way to engage Canadians across Canada in this event.

"Pride is the result of a compelling vision, a really well thought out plan where people can contribute and participate, and successful delivery of that plan," said Furlong.

Vancouver Sun reporter Jeff Lee said, "You can't underestimate the impact John Furlong has had on the Games. He wore his passion on his sleeve so broadly that you could not help but believe that whatever he said he was going to do, he was going to do. From a public support management point of view of building support for the Games, I think that Furlong probably was the single-handed weapon on this. He 
had this tremendous positive outlook. Whatever he thought Canada needed to do, Canada would do. It was that kind of enthusiasm that got people wanting to be part of the project."

"John always believed it was "Canada's Games" and the organizing committee really tried to do that. The goal was to make all Canadians feel they were part of it. That was a vision that John had, and it's one of the reasons it really was Canada's Games and not Vancouver's," said Tim Gayda, responsible for the management of the sport competitions at the 2010 Games and currently President and CEO for Sport BC, which promotes amateur sports in British Columbia.

A factor that helped with the implementation of the vision was the recognition that there were two distinct communities that needed to be engaged differently: the local Vancouver community, and the rest of Canada. The level of interest and support shown by these two populations was different, especially in the pre-Olympic period as the plans for the Games were being finalized.

Globe and Mail reporter Stephen Brunt, who has covered every Olympic Games since 1988, said Vancouver's mood before the Games was typical. "Host cities are always grumpy beforehand because they deal with the issues for seven years. They have some very good and necessary political debates about whether to stage the Games, spend the money, and how it should be done."

"I've been in lots of host cities in the year before the Games happen, and I've never been in one where the people were happy. Vancouver's grumpiness was 
absolutely typical. The rest of the country is generally blissfully ignorant of it, unless you have a "big O" situation where we spent a billion dollars on a stadium," said Brunt, referring to the high construction costs and functional problems which plagued the Montreal Olympic Stadium built for the 1976 Games.

Furlong said, "as you crossed the country from Newfoundland to Montreal to the West, there was a great euphoria building and you could feel it. It was quite easy to communicate and grow expectations across Canada because people living outside of Vancouver were not living the challenges of putting on the Games as Vancouverites were. People in Vancouver were hedging their bets more. They had seen us go through the highs and lows of a project like this... Until we were very near the end, it didn't become clear to the local community that this was going to become something magnificent. The rest of the country was already there because they weren't part of the challenge of trying to get it all ready."

While VANOC was implementing its vision for the Games across Canada, igniting interest and enthusiasm along the way, its strategy for Vancouver was different. For two years before the Games, teams of VANOC community relations people - often coupled with an RCMP officer - visited tens of thousands of businesses in the Vancouver area to educate people about what to expect.

"There was a lot of fear out there. We had a lot of fear mongering, with people saying there would be armed guards on every street corner and that streets would be shut down. We had to be out there in equal force saying this is absolutely 
not going to happen. People needed to know that they could still get to work, or run their businesses," said Stephanie Snider, who worked in community relations for VANOC.

"It was mostly public education awareness about transportation, to tell people which the roads would be closed so they were confident that they could still run their businesses, that their customers could still get to their stores, and that their garbage would still be picked up. We paired up with the RCMP because security was a major reason some roads had to be closed. We wanted people to know that security was there to provide reassurance, and that the police were not there to prevent people from doing their day-to-day work. That worked really, really well. We talked to as many people as we could," said Snider.

This type of stakeholder engagement happened in all Olympic venues, including Vancouver, Whistler and around the Richmond oval. Douglas said, "We listened and made changes to venue plans. We adjusted environmental plans. We heard what people were saying to us and went back to the drawing board wherever we could. The public was blown away by that. We went out and talked directly to people. We gave answers wherever possible. It did wonders for our integrity. People believed me. It's easy for people to NOT believe you."

\section{Torch relay}

The Olympic torch relay was described by many as one of the key factors responsible for igniting pride across Canada. Starting on October 30, 2009 in Victoria, 
BC, the Olympic flame travelled 45,000 kilometres over 106 days, and visited 1036 communities. Twelve thousand torchbearers carried the flame from the West coast to the East coast and back again in time for the February 12, 2010 Opening ceremony and the lighting of the Olympic Cauldron. The event was a commercial initiative, sponsored and organized by RBC and Coca-Cola.

"We decided that the best way to get Canadians to really feel the glow of the Games was to take the Olympic flame down every highway and byway in Canada, into every community we could get to. Our goal was to bring the flame to within one hour of 95 per cent of people, no matter where in Canada you lived. We achieved that. It was not easy to do, but we pulled it off," said Furlong.

Reporter Lee said, "At the time he made this announcement, most of the journalists in the room were quite skeptical. We're such a vast country, how do you do that? Interestingly, I think he did. The torch relay was just one more pillar in this remarkable house that Furlong and the bidders put together."

CTV journalist Marc Dinsdale, who managed the CTV Olympic web site during the Games, said, "The torch relay took me by surprise in terms of how big it became and how quickly it became a story. We all thought that the torch relay would have an impact, but were surprised at the incredible stories of family and of history that came out of the people who were carrying the torch."

People of all ages participated, and travelled with the torch by running, walking, cycling, rowing, canoeing, surfing, dragon boating and using other modes of 
transportation. Torch relay participants included cancer patients and people with disabilities, athletes of all abilities, teachers, students, people of all professions, and people with many stories to tell.

Hundreds of stories about torch relay participants and videos of the flame travelling through Canadian communities were posted on the VANOC and CTV web sites, and on the public YouTube and Facebook sites. Community newspapers across Canada ran stories about local torch relay runners and how the relay came through their community, and news and alerts were sent via Twitter. While the event was promoted in each community the torch travelled through, the event was also widely covered by the local media.

"I live in Toronto and remember the day the torch came through town sometime in December. We decided to walk to see the torch, and when we got there the streets were jam packed with people who had walked up to half an hour to see the torch come by. You start to feel that people are understanding that this is really an important symbol in everybody's lives, and that this doesn't come by that often. The visuals were amazing," said Dinsdale.

"The torch relay became a vehicle. The effect of it was that it stirred up a kind of flag waving patriotism in Canada. You could be blissfully unaware that this was happening, but as the relay was creeping through little towns in New Brunswick, Nova Scotia or Quebec, it was doing something. Something was happening," said Globe and Mail reporter Stephen Brunt. "For the people I ran into, it was profound 
for them. I was very moved by some of the stories. They were just normal folk. When they picked up the torch and ran through their hometown, it was emotional, it was special.“

While the torch relay exceeded people's expectations across Canada, it went according to the organizer's plan. "We wanted to make these Games accessible to the nation. We wanted people to feel they were part of this journey. It was about making these Games about who we are as Canadians. That drove how we did things. You don't need to have fancy gala events going into the Games, you can effectively do a lot of grassroots activities," said VANOC's Douglas. Before the torch relay arrived in each community, VANOC provided community leaders with several tools to use, such as a guide on "how to celebrate the Games in our community" which contained 30 "cheap and cheerful" things to do. "We did not have huge budgets, so we had to be creative with our partners across the country."

The year before the Olympics was to open, VANOC also organized an event to run on February 12, 2009, at 6:00 PM in every time zone across Canada called "Let's make some noise". The event encouraged people across Canada to beep their horns, ring their church bells, bang their hockey sticks, or just generally to make noise. Douglas said this event was a big success and that several communities did very creative things. For example, in St. John's, boat operators performed a harbour symphony during which all the boats in the harbour blew their horns to create a musical symphony. Despite the distance from the Vancouver Olympics, Douglas said 
that communities in Newfoundland were very engaged, excited and proud to be hosting the Olympics, and organized many Olympic-related activities.

\section{Red mittens campaign}

It was called "red mitten fever" by VANOC organizers and the media alike. The red wool Olympic mittens for sale before and during the Olympics were designed to be part of the torch relay participant uniform, as a souvenir, and as a way for people to support Olympic athletes. Net proceeds from the sale of the mittens provided funding for the Own The Podium program and other Canadian athlete-related equipment and training. More than 3.5 million pairs of mittens were sold during the five-month campaign and the mittens quickly became one of the most enduring and popular items of the pre-Games and Games time period (VANOC, March 5, 2010).

According to reporter Jeff Lee, the red mittens campaign was one of the most important and successful initiatives designed by VANOC to get public support and generate public pride. "But, I don't think VANOC had any idea of what they had on their hands. It was an accident. In the Olympic world, there are all sorts of rules including what the torch relay uniform had to look like. The IOC controls the design of everything. If they don't like it, you don't do it." He said that despite initial VANOC reluctance to pursue the red mitten idea, it decided it had a real opportunity to create something that was inexpensive, that had a donation component towards the Canadian team, and that had a Canadian emblem on the mittens. Despite IOC branding rules, the mittens were a success. 
As stated in a VANOC news release (March 5, 2010), "since VANOC launched red mittens last fall to raise funds to support Canadian athletes at the 2010 Winter Games, red mittens have been seen on the hands of a prince, a premier, a prime minister, the IOC President and millions of proud Canadians and worldwide visitors."

Public reaction to the mittens can also be seen on hundreds of photographs and YouTube videos posted on the web by individual people, showing people wearing the mittens during the Games, on the streets, and when the torch relay came through their towns and cities across Canada. Torch relay organizer Jim Richards said that people watching the torch relay in every town lined the streets wearing red mittens. "This is not only connecting Canadians to the Games but Canadians to each other," he said.

\section{Cultural events and activities in Vancouver}

Anyone watching media coverage of the Olympics would have seen image after image of street life in Vancouver and the crowds of people in Robson Square, one of the areas blocked off to traffic that featured cultural events and activities and encouraged celebration. There were giant television screens showing events live, and the streets of Vancouver became a large outdoor party.

As Brunt said, "If you were there a week before the Games, the transformation of the city is what struck you. There was gloomy, grey Vancouver with people complaining about stuff, then a week before the Games, Vancouver was this whole other place. It was different. I think people taking to the streets made the 
difference. It was a young crowd. It was a happening crowd, but it never tipped over to something ugly. The cops did a great job. It was just a bunch of happy young people - a pan-ethnic crowd that looked like Canada."

"This is kind of a new thing, it has never happened before," said Brunt. "This wasn't planned. They blocked off some of the downtown area and planned the pavilions and Granville Island. But the downtown celebration was pretty much spontaneous. People just took over the downtown. At other Olympics, you would see fans milling about, but I haven't seen anything quite like this. It just happened. That was the beauty of it, it wasn't contrived."

As a result of the street party atmosphere and the number of activities and cultural events organized for Vancouver, many Vancouverites changed their minds about the Olympics. For example, Vancouver resident Christine Brandt was completely swept up by the Vancouver Olympic spirit and went from being a skeptic to a supporter more than happy to talk about her pride during the Games. Brandt lives with her 7-year-old son and partner in the west-end section of downtown Vancouver, a 15-minute walk from most of the celebrations.

"Initially, I was not favourable towards the Olympics. I thought the city had a number of higher priorities to allocate its limited available funds to a wide range of social problems, such as homelessness, affordable housing and mass transit. I felt that the city would be better served to put its focus and attention and funds on programs that I thought were very worthy, rather than having the Olympics, which 
would be a huge tax drain," Brandt said. Brandt also felt there was insufficient disclosure about the full projected costs of the Olympics and how those costs changed over time.

"Then, the Olympics came to town and there were a huge number of cultural events that were a lot of fun. The city came alive and became a truly international city. It had street life $24 / 7$. It was very positive. Everyone was highly charged and very excited about what was going on, and it was pretty contagious and hard not to get swept up by that spirit."

In advance of the Games, Brandt said there was a lot of information to prepare Vancouver residents about traffic and parking, but after four or five days, most people realized transportation wasn't an issue. “Everyone managed. It wasn't the huge inconvenience people were expecting."

"There were a number of things that touched me. The highlight was the final Sunday when the Canadian men's hockey team took gold. There was a complete outpouring of enthusiasm in downtown Vancouver where you had anyone from an 80-year-old immigrant from China who barely spoke a word of English shouting 'woohoo' to toddlers playing road hockey in the downtown core. It was just amazing to see that and experience that," Brandt said.

"You could be a total stone and have been moved by that. It was impossible not to be moved. The downtown area had a number of big screen TVs where you could go and watch coverage of Olympic events with all kinds of other people." 
"There were a number of things that happened when the Olympics got underway. Whatever doubts I had just kind of melted into the ground, and I was completely swept up by the Olympics experience itself. Vancouver did an amazing job of hosting. It really showed the world what an incredible place it is," said Brandt.

\section{Volunteers}

Volunteers working at the Games also expressed pride for their role as volunteers and this was often contagious, spreading to other volunteers and the general public they came into contact with. In total, 21,000 volunteers worked at the Olympics, with 5,000 volunteers working at the sport competitions. Gayda said there were close to 50,000 applications from people wanting to volunteer.

"Volunteers are the face of the Olympics, and they created the atmosphere of the Games," said Gayda. "Anyone coming to Vancouver or Whistler was greeted by a volunteer. Canadians in general are very welcoming and the volunteers were always willing to help. That really set the tone. Everyone's first impression of the Games or the city was always super positive. People were saying how great the locals were not just the volunteers, but the whole city embraced the Games and everyone was super proud of their town."

On Whistler mountain, there were 2,500 people working at the alpine ski race venue alone, which included about 1,500 course workers that were on hill. The onhill volunteers looked after everything from the preparation of the snow on the run to the running of the physical race. This was done for every sport. 
While the 16,000 non-sport volunteers greeted people, gave out information, and provided directions - all which required minimal previous experience - the 5,000 sport volunteers often had to spend years in advance to get the qualifications and experience necessary to do the jobs they were given to do.

"The nice thing in Canada is that there is a really good base of volunteers," said Gayda. "We had volunteers from across the country that flew up on their own dime. We hosted everyone once they were on the ground. That drove a lot of the sense of nationalism. They're dedicated to their sport. This is really the pinnacle of their sport. To be involved in the Games for all these volunteers who have dedicated years and years of volunteering in local races was for them that magic moment. If you're going to dedicate your life to a sport, then to work at the Olympics is quite an accomplishment."

Jane Macintyre was one such volunteer. She wrote a daily blog during the Olympics called: Jane's 2010 Olympic Adventure, and described herself as "a 45 year old wife and mother of two wonderful children. I love ski racing and am embarking on a life long dream to be a part of the Olympics. I will be in Whistler, BC as part of the Ladies Alpine Skiing Course Crew from Feb. 11 to 27th, 2010. What an adventure it will be!!" Maclntyre lives in Chelsea, Quebec. Maclntyre's blog documents her volunteer experience, describing the hard work she performed, the 3:00 AM morning starts, the excitement of seeing ski racers compete, and the overall sense of feeling happy and proud to have volunteered at the Olympics. She was one example of a 
volunteer who prepared for the job, working happily during the Games doing whatever was demanded of her, and claimed that in the end, volunteering at the Olympics was everything she hoped it would be.

Another volunteer, Cheryl DeLeeuw, was similarly prepared but had a somewhat different experience at the Olympics. DeLeeuw was the Head of Start for the men's ski jumping events, and was in charge of a crew of eight people working on the $90 \mathrm{M}$ and $120 \mathrm{M}$ jump. In order to work at the Olympics, DeLeeuw started working as Head of Start two years previously at Continental Cup and World Cup events in Canada. DeLeeuw had also volunteered at the Calgary Olympics in a different capacity in 1988.

DeLeeuw's motivation to volunteer stemmed from her desire to be with her children during the Olympics - both of whom had expected to compete for Canada at the Olympics but neither of whom did in fact compete. DeLeeuw's son Yukon narrowly missed qualifying for the Canadian team in the months leading to the Games, and her daughter Nata was unable to compete because women's ski jumping was not endorsed as an Olympic event, despite considerable efforts and protests on the part of the athletes, their families and the Canadian sports body that governs women's ski jumping in Canada. In the end, DeLeeuw's entire family was at the Olympics: she and her husband volunteering and her two children working as forerunners for the jumping events. 
"I was quite excited about volunteering, but also tired of working at ski jumping events because we had to give up so many of our holidays to work at the Continental Cup and World Cup races to prepare for the Olympics. As it got closer, we just wanted to get it over with. It took so much work to prepare for the Games," Deleeuw said.

When the Olympics began, the volunteers had to work very hard. "We had to get up at 5:00 AM. Transportation was ridiculous. Then we were at the hill until 4:00 or 5:00 PM every day. The kids had to get up at 4:00 AM. They were staying in Squamish so the bus trip took even longer. They were staying on an old cruise ship with the other forerunners and other volunteers, and it was really horrendous. It was guarded so heavily that they weren't allowed on or off regularly. They called it "the prison ship". Nata was there for 2 weeks, but Yukon was there for 4 weeks," she said.

“My goal was that we would all go out and have a good experience. It was a good experience, but it wasn't the highlight of our lives or anything like that," DeLeeuw said. "However, I did get caught up in the excitement of it. It was hard not to. Even though we worked really long and hard, I felt a real sense of ownership at the ski jump and knew that the jump wouldn't go on without me. I had to get to the start every day to organize everything and make sure the athletes were where they were supposed to be."

"I think I always feel pride in being Canadian, having such a beautiful country and showing it off. I was very proud to be volunteering at the Olympics because it all 
went off without a hitch. I felt huge pride that a group of friends from Calgary could put on the ski jumping events at the Olympics without any outside help at all. It was a huge accomplishment," said DeLeeuw.

\section{Summary}

As this chapter demonstrated, VANOC had specific goals for Canadians to feel proud during and after the $\mathbf{2 0 1 0}$ Olympics, and specifically planned activities, initiatives and "tools" that would help achieve this. Some of the more successful initiatives used by VANOC to enhance Canadian pride included its vision and leadership, the torch relay, the red mittens campaign, the cultural events held on the streets of Vancouver, and the involvement of volunteers. In particular, the organizing committee's vision to host "Canada's Games" was a planned approach used in all activities, and was one of the most important contributing factors responsible for the success of the Olympics in generating pride.

While these initiatives were specifically designed by VANOC to increase pride, there were other factors that were important, such as the success of Canadian athletes, the role played by the Own The Podium program, and the strategic use of communications. 


\section{Chapter \#3: Athlete success and pride}

While several events and activities were already igniting pride across the country and in Vancouver before and during the Olympics, an ongoing discussion about the importance of athlete success at the Games had been underway for years. How important was it for Canada's athletes to win medals at the 2010 Olympics, and how many medals should they win? What would the impact of winning or losing be on the country or the athletes? How important would winning be to national pride, and would Canadians feel differently about the Olympics or about Canada if our athletes won or lost?

The academic literature on the link between athlete success and pride largely concluded that there is a link, but questions whether a medal index has the ability to arouse national emotions and increase national pride. Van Hilvoorde, Elling and Stokvis stated that goals to win a specific number of medals - similar to the Own The Podium program - create a 'narrative of expectancy', which defines what we, as a nation, are worth. For example, this is what we should win, otherwise we fail (Van Hilvoorde, Elling and Stokvis 93).

However, organizers, athletes and the media were more convinced that there was a direct link. Here is a sampling of comments made during interviews with representative sources: 
Organizers:

- "It was mission critical. The success of the team was a critical component to the success of the Games and it was viewed as a nation builder." (John Furlong, CEO of VANOC).

- "You can't get the results without the money. Good results unite the country and the fabric, and I saw that in Vancouver. It's the first time I've seen that kind of uniting factor making us proud to be Canadians." (Alex Baumann, President of OTP)

- "Where you had more investment in sport, you had more medals, and where you had more medals, you had more heroes. And therefore you had more pride." (Maureen Douglas, VANOC Communications)

Athletes:

- "Athlete success is really important. How do you define success? How many medals we won? Did we inspire the nation? How did we handle defeat?" (Mellisa Hollingsworth, skeleton athlete)

- "Results inspire Canadians. Of course you always dreams about the gold medal and that was my intention at the Games." (Eric Guay, alpine skier) General public:

. "Obviously, when you have athletes who place and win medal in the Olympics, it can't help but make you feel proud. It does have an effect. Is it 
essential? No. Does it boost your sense of pride and enthusiasm? Of course." (Christine Brandt, Vancouver resident).

Media:

- "It is the truth in all amateur sport that money buys medals. If you want to win medals, you have to spend money. It still would have been a great event and would have still been a big party in Vancouver if we hadn't won as many medals, but I'm not sure it would have had quite the impact if all those medals hadn't started popping up." (Stephen Brunt, Globe and Mail reporter).

- "Nobody wants us to go to Games and not win medals." (Jeff Lee, Vancouver Sun reporter)

Alex Baumann, president of the OTP program, argued that athlete success and pride go hand in hand. "The whole uniting, patriotic sentiment you get out of being successful is important, and the role models you get from the athletes themselves are an important by-product for our youth and for kids to hopefully get involved in some kind of physical activity or sport in the future."

While success matters to national pride, it also matters to the business operations of the hosting country. As Baumann said, "When you're putting a lot of resources into the Games, you ultimately want the host country to do well. It matters." Canada hosted two earlier Olympics and did not win a single gold medal. In 1976, when Canada hosted the Summer Olympics in Montreal, the country won five silver and six bronze medals. In 1988 at the Calgary Winter Olympics, Canada won 
two silver and three bronze medals (DatabaseOlympics.com). In planning for the 2010 Vancouver Games, organizers decided to address the gold medal drought with a plan of action.

\section{OTP and athlete performance}

To remedy this medal drought and build pride in athletes and their performances, Canada launched the "Own the Podium" (OTP) 2010 program in January 2005. OTP was a national sport technical initiative designed to help Canada's winter athletes win the most medals at the 2010 Olympic Winter Games in Vancouver, and place in the top three nations (gold medal count) at the 2010 Paralympic Winter Games.

The initiative was a collaborative effort supported by all of Canada's winter national sport organizations (NSOs) and major winter sport funding partners, including the Government of Canada through Sport Canada, the Canadian Olympic Committee $(\mathrm{COC})$, the Canadian Paralympic Committee $(\mathrm{CPC})$; the Calgary Olympic Development Association (CODA); the Government of British Columbia; VANOC, and several of VANOC's corporate sponsors, including Bell Canada (VANOC Business Plan and Games Budget 35).

Own the Podium 2010 had established partnerships with governments, sport agencies and corporate sponsors to develop long-term funding stability for the winter sport system. The heightened awareness of athlete and amateur sport needs and the anticipated performances of Canadian athletes at the 2010 Winter Games 
were expected to create an increase in the level of support from all sectors for amateur sport after the Games (VANOC Business Plan and Games Budget 35).

Baumann managed a similar program in Australia in 2000, when the Australian team set a goal of winning 60 medals at the 2000 Summer Olympics, held on home soil in Sydney. Baumann said the goal seemed almost impossible, but people started believing that the goal could be achieved, and ultimately the athletes won 58 medals and came $4^{\text {th }}$ overall. Baumann had been working with the Queensland Academy of Sport and Queensland Swimming at the time, and was responsible for overseeing sport programs, athlete and coach support services, regional services, and the Centre of Excellence for Applied Sport Science Research to ensure Australian athletes had the best resources necessary for attaining podium performances at Olympic and Paralympic Games. Before that, Baumann was a celebrated and highly successful Canadian swimmer, with medals from several Olympic Games, World Championships and Commonwealth Games to his credit.

In January 2007, Baumann returned to Canada to become the Executive Director of the Road to Excellence (RTE) program, a summer sport technical program that aimed to re-establish Canada internationally as one of the top sporting nations in the world. He became interim CEO of OTP in April of 2010. "A similar kind of experience happened in Canada, where you put up a robust goal. It's a realistic but still far-reaching goal. You put all your energies into achieving that goal as long as all the people involved believe that it is possible," he said. "It all starts with a goal." 


\section{How OTP works}

The goals of the OTP program for the 2010 Games were to place first in the total medal count at the 2010 Olympic Winter Games, and place in the top three in the gold medal count at the 2010 Paralympic Winter Games. The program also aimed to strengthen national policy, programs, the sport delivery system and commitment to excellence for winter and summer high-performance sport.

To fund athlete preparation for the 2010 Olympics, VANOC raised $\$ 55$ million through its sponsors while the federal government provided $\$ 55$ million for a fiveyear total commitment of $\$ 110$ million for winter sports (OTP web site). During the Winter Olympics, this worked out for $\$ 22$ million per year, plus an additional $\$ 5$ million from the COC and sponsors, making a total annual contribution of $\$ 27$ million for winter sports last year, Baumann said.

The funds were used to encourage the development of Canadian sports to win medals at the Olympics, with a focus on funding those sports that showed potential for medals. OTP funds were used for coaching, athlete medical, performance and sport science support (like sport psychologists, nutritionists, physical therapists and physicians), and for Canadian sport institutes.

In practice, this meant that the sports that showed the most promise got the most money. For example, alpine skiing received $\$ 2.645$ million a year, followed by bobsleigh and skeleton, which received $\$ 2$ million a year. This was in contrast to biathlon, which received $\$ 431,325$ a year and men's ski jumping, which received 
$\$ 137,500$ annually. The four-year total spending for winter sports during the Vancouver quadrennial - from OTP funding and additional funding - showed a significant increase from the previous quadrennial for all sports.

"You need to have that support if you're going to be world-leading," said Baumann. At the same time, the federal and provincial governments agreed to contribute another $\$ 110$ million ( $\$ 55$ million each) for what was the Games Legacy Operating Trust. It was specifically designed to pay for the future operations of the Whistler sliding track, the Richmond oval, and the Callaghan Valley Nordic Centre.

"This was really important because as we went into this economic downturn that really took the bloom off the rose, nobody had to worry that we wouldn't have enough money left over from the Games to pay for these things. At the same time, this Games operating trust largely removed the possibility of Canada being left with a massive debt, and this gave permission for Canadians to feel good about the Games," says Lee.

\section{Did OTP work?}

Determining whether OTP was successful required some simple mathematical analysis of medal counts and funds spent, and a review of its goals. Canada did not place first in the total medal count at the 2010 Olympic Winter Games (it placed third), but it did win the highest number of gold medals of all countries, exceeding the goal of placing in the top three in the gold medal count. While the OTP did not meet its goal in total medals won, however Canadians seemed satisfied to see the 
program redefine its goal to winning the most gold medals, and at that Canada succeeded. On a sport specific level, not all of the sports funded by the OTP program won medals. For example, alpine skiing, biathlon, cross country skiing, luge and nordic combined - all which received OTP funding - did not produce any medals. However, as Baumann pointed out, none of the sports that weren't funded by OTP produced medals either.

"In the end, we are funding a performance-based system so you do have to perform. All in all, there were some disappointments but the sports that used the resources well performed well," said Baumann. "We based funding on high performance plans and made adjustments where needed. It's a new quadrennial, so we do a proper review process, and the sport bodies have to submit new plans. We do an examination every year."

For the coming quadrennial for Winter Olympics, which will be held in Sochi Russia in 2014, there will be a slight decrease in OTP funding to $\$ 21$ million a year, which is down from the $\$ 27$ million a year that winter sports shared this last year. Adjustments in funding levels will mean that some sports will get more and some will get less. There was speculation that women's ski jumping would be accepted by the IOC and that it would then get OTP funding, however the IOC announced in late October 2010 that it needed more time to review this decision (CBC news release, October 25, 2010). In preparation for the 2012 Summer Olympics in London England, sports will receive $\$ 36$ million per year from OTP until the Olympics, plus an 
additional $\$ 4$ million from $\mathrm{COC}$ and $\$ 300,000$ from the Paralympic Committee, then this will be re-evaluated after the Games, said Baumann. These funds are to support the OTP's goals of placing in the top 12 nations in total medal count at the 2012 Olympic Games, and placing in the top eight in the gold medal count at the 2012 Paralympic Games.

Despite earlier uncertainty about whether the OTP program could work and whether it was properly structured, the post-Games opinion about the program was largely supportive, given that it was successful in attaining gold medal results (see public opinion poll results in Chapter 6). As Tim Gayda said, "our old Canadian model was that we would try to medal in everything, but end up getting medals in nothing. To be strategic in how to invest money at a high performance level is a very wise move. Obviously, it paid off and that's what the smart nations are doing. They're not investing in high performance across the board. To be good at something, it does cost. Countries a lot smaller than ours are investing a lot more than we are in some sports. They're not trying to do everything and be everything for everyone."

"It's a very smart investment, and it's creating new heroes which is good, because right now in Canada, our heroes are largely professional hockey players. I think our Games have made new heroes of amateur athletes," Gayda said.

While it was a good investment for those sports that were funded, there was dissatisfaction expressed by some people in sports that weren't funded. As DeLeeuw said, "coming from a sport - ski jumping - that didn't really get any money, I think 
they did a good job with OTP but I think the money should have been spread more equitably. For example, they gave all that money to alpine skiing and then everyone got injured."

Prior to the OTP program, Canada divided its resources amongst all the sports and it didn't really make any difference, said Baumann. In the end, OTP had to make some difficult decisions in terms of where to focus resources, based on past historical results and on what the future holds, what the medal potential of each sport would be. A significant amount of statistical analysis was needed to be able to predict where the medals would come from and who the winners would be. Impact of OTP on athletes

The impact of the OTP program was different for different athletes. For skeleton competitor Mellisa Hollingsworth, the impact of OTP was nothing but positive. Although she finished fifth in her Olympic competition despite expecting to win, Hollingsworth was appreciative of what the OTP program provided her in the years leading up to the Games.

"Our funds went to the wind tunnel where we learned about being aerodynamic. That's the number one need to be fast on the Whistler track, to be aerodynamic. They helped us with our housing so we could be out on the track. Most of us moved to Calgary long ago because this was the only facility to train at. Since it was too expensive to move to Whistler to train there, the funding paid for our accommodation, the cost of training, and the costs of our support staff, physios and 
coaches. We had access to everyone we needed so we could be our absolute best," she said.

As for the extra pressure some athletes felt because of the medal expectations, Hollingsworth said, "as an athlete, I enjoy being in that pressure cooker situation. I thrive in that sort of environment. I don't believe pressure had anything to do with my fifth place result. I didn't have pressure. I had my goals and just wanted to fulfill them. Canadians should be able to come out and state their goals." “My personal goal was to win gold. It's one thing to say what your goal is and be wishful about it. But I was the number one slider on that track so it was a realistic expectation, " she said.

Did her lack of success play a part in the pride she felt and whether Canadians were proud of her? Hollingsworth said pride is about more than winning and success. "As an athlete, I feel proud of how we handled ourselves in the media, and what kind of people we are with our competitors and our peers. It's who we are as people: kind and giving. We don't let people walk all over us. For example, people thought it was very un-Canadian of us to not open up the sliding facilities to allow other athletes to practice as they pleased. That's not how other facilities operate, so why should we?" "In my opinion, these Games were over the top successful. Not just in medals, but how people reached out. We found a new definition of Canadian within us. 
I don't know how to separate me as an athlete from me as a Canadian. Every morning I wake up and put on my Canada suit. I'm always a Canadian, and proud of it," said Hollingsworth.

Alpine skier Eric Guay scored two fifth place finishes in the downhill and Super-G events at the Olympics, narrowing missing the podium and not happy about it. "Of course you always dreams about the gold medal and that was my intention at the Games. So it's a little bit tough when you walk away with nothing, but at the same time I think I finished the season the way I wanted to," Guay said.

"In terms of OTP and the funding, I think that initiative was an essential part of our progress, but I didn't think it was right for them to say they wanted this many medals and that the results were going to be there, when it's the athletes who have to do the job,"

Guay also expressed some concerns with the way the OTP money was spent and the results it achieved with alpine skiers. "It's a work in progress. On the alpine side, we could have probably put those funds to better use. For instance, we invested some money in GPS technology and in my opinion, it didn't bring a whole lot to the table. We couldn't use it. It wasn't very functional because it was big and bulky so we couldn't train with it on a daily basis. It was supposed to allow us to compare on the computer different lines and different accelerations and see exactly where we lose time or gain time. But of course it would have to be practical for us to use on a daily basis. Which wasn't the case. The technology wasn't quite there. Hopefully, in the 
next few years they'll be able to get that smaller and then we will be able to use it on a functional level."

However, OPT funding did help significantly with training. "Our training was phenomenal heading into the year, which might not have been possible without some of the funding. We were also able to get onto the Olympic downhill track, which was crucial for us. Little things like that make a big difference in the long run," Guay said.

Did Guay feel pride as an athlete? "I would say that the outcome was phenomenal. You would see seas of red everywhere and people singing Oh Canada. Everyone turned out to support our athletes and I think that was the most important thing. One thing the OTP did well was to inspire Canadians and say 'hey, stand up and watch our athletes'. And they did a good job of that."

Impact of OTP on Canadian pride

“Canadians are very humble and we're just proud and welcoming as a people," says Gayda. "OTP changes the dynamic for sure. You look at the US and they say "we're going to be number one" with confidence and a certain kind of arrogance. But in Canada, we say "well, we want to be number one." It's a bit of a departure for what is typically Canadian. We were never really that loud and proud about how great we were doing compared to everyone else. In the end, we pulled it off in terms of the most gold medals ever, but I think everyone was shocked by it." 
"I think people were a little squeamish about it in Canada at first, because we like to think of ourselves as people who don't care about stuff like winning. I think it's part of the national myth of politeness and our willingness to back off and let others take the glory," Brunt said. Douglas echoes this: "Canadians equate success and a commitment to success with a certain type of persona that we're not that comfortable with."

Baumann said one of the things that OTP brought Canadians was the permission to win, and the acceptance of the idea that it was not a bad thing to try to win, and to be the best in the world. Philosophically, this was new and different for Canada. It was a departure from the Canadian philosophy of egalitarianism. He said this was a significant departure that probably started in 1988, after the Ben Johnson win/controversy and then became more focused in 2003 when Canada was awarded the 2010 Games. He said the first signs of success were at the 2006 Torino Olympics, where there was more of a focus on excellence, and it was considered acceptable to try to be the best in the world.

Michael Chambers, the past-president of the Canadian Olympic Committee $(\mathrm{COC})$, argued that "the pride that swells in people in an event like the Games causes the people of that country (wherever they may be) to feel that much better about themselves. It causes many people to be more productive in their lives because they feel so good about themselves. I'm sure Canada's productivity was very high in the week following the Games, because people felt so good about themselves. They felt 
good at work, good at home, good about their interchanges with their fellow citizens."

"You don't have to be a college grad to know that people are more productive if they're happy and feeling good about what's happening in their lives," said Chambers. "What other things can make an entire nation feel good about their lives? Very few things other than an Olympic Games where there is success realized in a country."

Not all medals were equal

While Canadians across the country were expressing their pride after every Canadian athlete won a medal, there was one medal that overturned the pride applecart and generated an unprecedented amount of national pride: the gold medal won in the final Canada-US hockey game.

Furlong described the last hockey game: "It was a big celebration in the streets of Vancouver and across the country, and everybody felt a sense of pride. Yes, Sidney Crosby may have been the person who wrote the final chapter in the whole story by putting the puck in the net, but what made this goal more important was that every Canadian felt they had a stick on that puck. They were living it. The country was really feeling like together we had done something pretty amazing."

"If we hadn't won that game, I think it possibly would have been different. By the time we got to that game, we had seen a lot of this celebratory behaviour already. But at the end of that game, the country was just feeling great about itself," 
said Furlong. "The thing is he did score it.... And I would have bet my home that we were going to win that game. We had somehow come to that place where Canada was about to have a "moment" and we had it. It did happen and it caused us to cross that threshold or that line that we hadn't been able to cross before."

Brunt disagreed about the importance of the men's hockey gold medal. "If they lost, it wouldn't have mattered. It was still the Olympics. It was a Hollywood ending - you couldn't have scripted it any better. But still, you had enough of those Jon Montgomery moments where people were swept away by that. The game was fantastic as a climax. By that point, the Olympics were already culturally what they were. If we'd lost the hockey game, people would have found a way to live with it, and say we'll get it next time."

Measuring the pride expressed by Canadians throughout the Olympics was an almost impossible thing to do, but there were many images and anecdotes shown on television, YouTube videos, blogs, newspapers, and in communities everywhere to support the common spirit of celebration and pride.

\section{Did success change anything?}

It appears that the success of Canadian athletes at the 2010 Olympics positively affected national pride. Every time the Canadian national anthem was played after a Canadian athlete won a gold medal - in Vancouver or on televisions screens across the country - people expressed pride. The Games appeared to change how Canadians looked at sport and how they looked at the nation. Whether this was 
a fundamental and enduring change or a short-lived change has yet to be determined. There is nothing like winning at home. It is unlikely Canada will host another Olympic Games in the very near future (there were 12 years between the 1976 and 1988 Olympics, and 22 years between the 1988 and 2010 Olympics). Can Canadians experience the same sense of pride if the Games are not on home soil, or if Canadian athletes do not perform as well at either the 2012 Summer Games in London or the 2014 Games in Sochi? Only time will tell.

Gayda said, "The Olympics Games success changed people's psyche that we can be number one. People noticed that the power of sport changed how people viewed their entire country. You just saw Vancouver and Whistler come together with masses of people all having a good time, all under control, all proud to be Canadian. It won't happen again, not in our lifetime. What caused that was the success of the Canadian team."

"For a nation, winning is a good investment. We might be spending millions of dollars on sport, but the pay-off is that you've changed the psyche of the nation. We walk around differently now. We act differently. We're more confident and it somehow came out of those victories, " Gayda said.

Baumann said, "We've gone from being happy to participate to caring a lot about winning. How does this affect the sport culture going forward? I'm hoping we continue it. Winning at all costs is not what we're after. What we're after is that we 
should focus on excellence and try to be the best that we can be. And ultimately, we can be the best in the world."

To the athletes, the OTP program holds much promise going forward. As Erik Guay said, "I think it is crucial that we have a program like this. Alpine Canada didn't get the results they wanted at the Olympics, but they had other great results throughout the rest of the year. Should they have a goal for how many medals should be won in the future? Some people need concrete numbers. For myself, I try not to look into that too much. I try to do my best on every single race and if the results are there - if it's a gold, silver or bronze - I'm happy with that and always thinking about moving forward."

While winning at the Olympics has been good for the way Canadians feel about themselves, their athletes and their country, there are other residual benefits to increased pride. Feeling good is rewarding in itself, but harnessing that feeling or the power of that emotion and applying it to something else has much potential. Can this success create a national sense of confidence that can spill over into other areas, such as business, education, science or research? Could it affect our national productivity or the way we relate to each other - nationally and internationally?

The lessons from sport are lessons that can be applied to many areas of life. Baumann argued that "winning at the Olympics has more benefits that just feeling good. It can translate into other areas. We can be more productive as Canadians if we really strive. Sport is just one area that we always strive and aim high and try to 
achieve. It's important for youth today to see that if you work hard, you can achieve great things, and this is something that the OPT program demonstrated. If you set your goals, and set your mind towards achieving those goals, then you can do great things."

Sharing the OTP experience

Canada's experience with the OTP program and the successful results at the 2010 Olympics did not go unnoticed by other countries. In fact, according to Chambers, the Vice-President of the Russian Olympic Committee has been looking at the OTP program, trying to learn from Vancouver's success so that Russia can implement a similar program in preparation for the 2014 Games, which it will host in Sochi. Russia finished the Vancouver Games with its worst Winter Olympic medal tally in history, winning just three golds, five silvers and seven bronzes to finish 11th in overall results. Russia's poor performance in Vancouver resulted in the resignation of the head of the Russian Olympic Committee following the Games, and the appointment of a new head to help guide the country towards success when it hosts the Games on Russian soil in four years.

"The experience of celebration and happiness and joyfulness was what the world took away from Vancouver. This had never been seen before at any Summer or Winter Games before Vancouver. The people embraced the Games and celebrated in obvious joy and happiness on the streets in the city. It was the first ever," said Chambers. 
Chambers said it will be a challenge for other hosting countries because they will feel the need to excite people in their own countries to the same extent that Canadians were excited. They want to find a model for generating excitement, increasing national pride, and avoiding the potential for conflict, corruption and hooliganism that often characterizes Olympics Games in other countries but was fortunately absent during the Canadian Games.

At an international meeting Chambers attended in Acapulco in mid-October 2010, Chambers said that IOC President Jacques Rogge said it is very important that the hosting country have very good results because wherever the Games take place, there is much more domestic celebration of them during the Games if the home team sees success.

\section{Summary}

Based on the Canadian experience during the 2010 Olympics, it was clear that athlete success had a direct impact on national pride, especially because Canada was the hosting country. Winning did seem to impact how Canadians felt about their athletes, their country, and their role as host. Although the academic literature on the link between athlete success and pride concluded that there was a link, the Canadian experience at the $\mathbf{2 0 1 0}$ Olympics showed how importance that link was.

Canada's Own the Podium program was designed to help Canada's winter athletes win the most medals at the 2010 Olympic Winter Games in Vancouver, and the number of medals won demonstrates that OTP did indeed work. Canadian 
athletes had exceptional success, and people living across Canada expressed pride in an unprecedented way. The lessons to be learned from Canada's experience are now being sought after by others, in particular Russia as it prepares to host the 2014 Games. Russian hopes are high that Sochi will experience a comparable level of success and national pride as was the case in Canada. 


\section{Chapter \#4: Olympic Communications}

The role of the media at an Olympics Games is complex as there are a number of requirements and responsibilities set out by the IOC for hosting countries - written or understood - by media covering the Games concerning their role and mandate. On the one hand is the host city organizing committee (VANOC), which uses strategic communications to promote the event, the ideals of the Olympic movement, the host city and country, and the sponsors involved - all of which happened under the watchful eye of the IOC. On the other hand are the media, many of which have paid dearly for the right to cover the Games and have a vested interest in their success.

This chapter will look at the role of the media in the 2010 Olympics with a focus on how the media and its coverage impacted Canadian pride. It will also examine whether the concentration of media ownership in Canada and the financial support provided by the Olympic Broadcast Media Consortium to attain broadcast rights affected the type of media coverage that resulted, and whether this affected Canadian pride.

Hargreaves argued that because television rights were a major source of financial support for the Games, journalists and broadcasters were increasingly subject to the demands of the television networks to capture the maximum audience and deliver it to the commercial interests (127). The next chapter (Chapter \#5) will 
provide a media scan of newspaper media coverage during the Games in an attempt to determine if the media influenced Canadians' perceptions and experiences.

\section{VANOC Strategic Communications:}

The IOC Olympic Charter has specific rules governing media coverage of the Games. It states, "it is an objective of the Olympic Movement that, through its contents, the media coverage of the Olympic Games should spread and promote the principles and values of Olympism" (97). The IOC establishes all technical regulations and requirements regarding media coverage of the Olympic Games in an IOC Media Guide, which forms an integral part of the Host City Contract. The contents of the IOC Media Guide, and all other instructions of the IOC Executive Board, are binding for any and all persons involved in media coverage of the Olympic Games. The Charter also specifies rules for publications, advertising, demonstrations, propaganda, commercial identification on clothing, uniforms and equipment, mascots, use of the Olympic flag, and the opening and closing ceremonies (96-103).

Furlong's view was that the Olympics were "a very big communications project." The original Vancouver 2010 Bid Book proposed a communications plan that included image building, branding and messaging for the Olympics. The bid book stated:

The Olympic image is already one that enjoys unparalleled global awareness and positive emotion... Our plan is for an integrated, staged image campaign that will rely on paid and donated media assets as well as exploiting the cumulative communication resources of our various commercial and governmental partners. Ensuring that governmental and commercial 
messaging around our Games is tied to and part of our overall Olympic messaging will reap tremendous benefits for our Games and the Olympic Movement. We want to ensure all constituents' Olympic communications activities are consistent with and complementary of our communications campaign (113).

McCallum, Spencer and Wyly noted that Vancouver's 2010 Olympic Bid Corporation "functioned as the dynamic and innovative image producer, attempting to craft place-based symbols that would be strong enough to impress the International Olympic Committee (IOC), an evolving transnational enterprise that works to balance pragmatic economic and logistical demands with the imperative to build long-term "legacies" through a succession of ephemeral but high-profile images from various cities. Vancouver's Bid Corporation presented a compelling and successful narrative of visual metaphors and local images, securing the votes of IOC members and other privileged viewing audiences" (26).

The 2007 VANOC Business Plan and Games Budget contained a communications plan that detailed how VANOC was going to manage its relationships and communications with key communities, stakeholders, influencers and the general public with a goal to creating high general awareness and strong public support for, and engagement in, the Vancouver 2010 Winter Games. The plan included strategies for communications services, media relations and specialized sport communications, editorial services, Internet management, marketing, community relations and workforce communications (157). 


\section{Controlling the message}

At the heart of the communications plan was VANOC's goal to control what was communicated internally and externally via a centralized team. It stated, "every time a function communicates internally or externally, it has the opportunity to reinforce the VANOC brand and to contribute to the image and reputation that will shape VANOC's internal and external reputation." All written, electronic and creative communications were to involve the communications team, which was also mandated to work closely with the CEO Office, Workforce, Brand and Creative Services, Marketing and Cultural Olympiad and Ceremonies.

The plan also stated that "externally, the local, national and international media will rely on Communications to be kept informed of the Vancouver 2010 Winter Games planning, VANOC's accomplishments and its challenges in order to effectively communicate to their audiences." (158).

Controlling the message to be provided by VANOC involved articulating what

that message should be. This was contained in the bid book, which stated that:

Locally, the Canadian love of winter sports and Canadian pride in our country's role as host to the world will be our greatest assets in communicating our message. We will ensure that every Canadian citizen understands the responsibility of our role as Olympic hosts, and the honour bestowed on our community. (Our) role is a seven-year process and we must and will remain cognizant that we will need to manage our activities to not only sustain passion and interest in the 2010 Games over that time frame, but to carefully create a program in which public support and excitement builds and reaches its crescendo in late 2009/early 2010. This will entail a complex and integrated communications campaign comprised of advertising, promotional and public relations activities (115). 
Lee can attest to this, and called VANOC's communications approach "a reputation management style of communications" because the Director of Communications for VANOC (Renee Smith-Valade) was a reputation management specialist, and she appeared to focus on maintaining the reputation of VANOC. Lee took particular exception to the way in which VANOC controlled information available to the media. He believes VANOC missed the opportunity for the public to get even more engaged in these Games because they held back information and mishandled the communications strategy. "I don't consider VANOC to be a particularly good example of public communications," Lee said.

"As a journalist, I think everything should be out in the public. VANOC never saw it that way. They were structured so you couldn't get information. It was a private corporation funded in part by the provincial and federal governments and equally by private corporations, but information was not accessible under the Freedom of Information or Access to Information acts. Anything that you got out of it came from a very, very, very structured communications strategy. You could not get information from them unless they chose to give it to you," said Lee.

To some extent, VANOC's control of the messaging extended to controlling the availability of records and copies of more specific communications plans after the Games, which were nowhere to be found during the research of this thesis. During a brief conversation, Smith-Valade stated that Canada would not host another Olympic 
Games for another 20 to 25 years, so there was no need to have these documents accessible as they would be archived. In fact, the City of Vancouver Archives is the repository for the archival records for VANOC, and put out a call on its web site in August 2010 for records about the Games.

"I argued with VANOC for years. They wanted Canadians to embrace and believe in what the Games could do through a transformative sport point of view, through the positive power of thinking, but if you then asked to see some of the stories about that, it would be very problematic." Lee said VANOC kept the media off site and conducted a media tour of the venues once a year as a very highly structured, highly organized, highly polished event. "This meant the media was being spoon-fed information unless you knew more than them. Many reporters just went off and reported it that way."

VANOC's Maureen Douglas said this control of messaging was more about practicality than approach. "Sometimes, the media felt we weren't transparent enough. They wanted to sit in our Board meetings with us. That's completely impractical. Our staff isn't sitting in the Board meetings."

Douglas described the implementation of the VANOC communications plan: "We had a giant key messages document, but we were so practiced in what they were that we didn't have to use them. We had a framework on how to do anything. We didn't work from scripts. We worked from who we knew we were. An absence of documentation was because there were spokespeople who were well trained and 
knew their issues. We were very "high road" most of the time. The local media wanted a good fight occasionally, but come Game time, the local media defended VANOC against the criticism of the international media."

There was also a crisis communications plan that Douglas said came from the IOC, which was put in place following the death of the luger. "You practice it so when you get into a time of crisis, you already know what to do. We managed the situation (death) as best we could. We had very well set out definitions of who owned what information. Instead of working from a plan, we had a set of communications principles that helped us. Beyond the big inspirational side of what we wanted to achieve, we were driven by the mission statement - to touch the soul of the nation." Broadcast rights and the role of media

The role of the Canadian media during the Olympics was very much dictated by whether they had broadcasting rights or not. In 2005, the IOC announced that it had awarded the broadcasting rights for the 2010 Winter Games in Vancouver and 2012 Summer Games to an alliance between CTV Inc. and Rogers Communications. CBC had held Olympic broadcast rights since 1996. IOC president Jacques Rogge said the winning bid was $\$ 153$ million US, an increase of 110 per cent over the $\$ 73$ million that CBC paid for the Canadian broadcasting rights for the 2006 and 2008 Games.

The CTV-Rogers consortium offered $\$ 90$ million alone for the rights to the 2010 Games, up 221 per cent from the $\$ 28$ million spent for 2006 Turin Games, and $\$ 63$ million to cover the 2012 Summer Games. This was the first time that the 
amount for the Winter Games exceeded the Summer Games (CBC news release, Feb. 9, 2005).

Given the dual requirements for the Olympic broadcaster to respond to the IOC's communications needs - that the media coverage of the Olympic Games should spread and promote the principles and values of Olympism" (Olympic Charter 97) and their own economic need to make money through commercial endeavours, it is possible that media coverage may be more positive than negative, and more supportive than critical.

Brunt, who worked for the Globe and Mail and the CTV web site - both part of the broadcast consortium - said, "nobody was at arm's length... There are a lot of blurry relationships in sports journalism. Newspapers sponsor professional sports teams across the country, and you can see their advertising in every arena in the country." The Globe and Mail was the official national newspaper of the consortium and the Vancouver 2010 Olympic Winter Games, and its staff writers also provided the majority of print content for the CTV Olympic web sites.

"In Vancouver, we were in a rights holder position... every one of us was a partner with the IOC. Olympic Games are a rights holder situation for broadcasters, and there's no such thing as a newspaper that's separate from a broadcaster anymore," he said.

“Coverage wasn't positive in the first few days. When the news was negative, the coverage was pretty negative... I would resist the notion that the media tried to 
change the reality of it. I think the coverage pretty much reflected what happened. If you look at the coverage of the dead luger or the opening ceremony screw up, they were covered to death. If more bad things had happened or Canada hadn't performed, that would have been covered to death as well," Brunt said.

Coverage of anti-Olympic protests was not extensive or plentiful, however stories about the protests were carried by CTV, CBC, Global News, Macleans, the Toronto Sun, and other newspapers. On the day before the Olympics opened, CTV reported that "more than 1,500 marchers opposed to a variety of things, demonstrated as the torch run ended and the opening ceremonies were to begin. When they got near the stadium where the ceremonies were being held, a threedeep line of officers held them back. Still, the protest was largely peaceful, with only one arrest after two officers were hurt during a confrontation." The next day, it reported that "conflict coloured the first day of Olympic competition on Saturday after a protest rally erupted into violence in downtown Vancouver, spurring a lengthy showdown between participants and police" (CTV News online, Feb. 13, 2010).

Given that the protests were organized by the Olympic Resistance Network, which stated on its web site that it represented a diverse network of groups and individuals protesting for a variety of causes, it is debatable whether the limited media coverage of protests was due to the lack of clear protest messaging (what exactly were protesters saying?), the ability of the police to quickly and peacefully control and subdue the protesters, or the apparent disinterest of Vancouverites and 
tourists in the protests? Alternatively, was the limited coverage of Olympic protests related to the role of the media in a broadcast rights situation, and the unwritten understanding that coverage would focus on the positive aspects of the Olympic Games?

While Brunt disagreed that the media ignored the protests and positively shaped the news, Globe and Mail TV critic John Doyle wrote: "Olympic TV coverage is what it is - traditional sports TV on a gigantic scale. It's not the TV news. It's not a vehicle for investigative journalism or, indeed, much in the way of soul-searching... Excessive belief in the right to national bragging rights is certainly something that can be examined in the context of TV coverage. Yes, there's bragging and boosterism. Yes, there's self-absorption. Yes, our Canadian TV coverage gets a gold medal for positive spin." (Globe and Mail, Feb. 16, 2010, R3)

For reporters covering the Games, the experience was different from most typical reporting assignments. "It was quite an experience. Being part of that larger consortium was quite something.... We had a huge dedicated research staff. Working during the Games, we had two or three people specific to each sports, working dayby-day in the research room... Normally, reporters just want to go home after covering an Olympics. No one had fun in Calgary. It was dreary. But everyone I know who covered the Vancouver Olympics would have gone back the day after and started all over again. I can't remember anyone ever saying that," says Brunt. 
Lee agrees and said at times it seemed too good to be true. "There were times when I woke up in the middle of the night worrying about whether I did my job professionally enough, and whether I missed something I should have reported on here because the history of the Olympics is that there's always trouble somewhere. This was one of those organizations that actually managed to avoid a lot of the trouble that other Olympic organizing committees had. I keep wondering to myself, did I do something wrong?"

\section{Volume of information}

Brunt said there was more and better media material than was ever produced in the history of the country for any single event. "Enormous quantities and enormous numbers of people who set out to do that by the combined forces of CTV and Rogers... It hasn't happened before. It will never happen again because there's not that moneymaking opportunity as with a home Olympics. You might get that in 25 years with another Olympics."

"I think that the anticipation of these Games was greater than any Olympic Games in history for Canadians because they were at home for the third time. There was also an incredible amount of resources available and dedicated to telling people who these athletes were and what their back-stories were. A year ago, you couldn't turn on the TV without running into something on the Olympics," he said. Indeed, there were 10,800 media representatives at the Games, including 7,000 rights holding broadcasters, 2,800 press reporters and photographers and non-rights 
holding broadcasters, as well as 1,000 host Olympic Broadcast Service (OBSV) personnel (VANOC news release, Feb. 28, 2010).

On the media consortium side, it seemed there were few limits to how much reporting and writing was done, and substantial efforts were taken to provide comprehensive coverage. Reporters like Brunt travelled overseas a year in advance to cover sports like alpine skiing and to get to know the athletes. "We never do that. We had a really good working knowledge of who these athletes were, what they did, why they were good, and how their sports operated because we travelled with the teams before the Games," said Brunt. "We generated a lot of good content even before the Games because it wasn't written over the phone. We had the resources we needed to do this."

\section{VANOC and CTV relationship}

The distinction between what communications VANOC was responsible for and what the media consortium took care of was also somewhat blurry at times. For example, both organizations created and maintained web sites and social media tools to provide essentially the same information but for somewhat different audiences. The goal of both organizations was to inform the public about the sports and athletes, however CTV served largely the Canadian audience while VANOC served the international audience.

Marc Dinsdale, who started with VANOC then moved to CTV to run the consortium web site in 2008, said that VANOC and CTV worked together and shared 
information, but they were also competitors in the sense that they often went after the same sponsorship dollars and had parallel web sites. "It was an interesting relationship because in lots of ways, the organizing committee and the media consortium both wanted the Games to be successful and worked towards that goal."

Graham Menzies, manager of the VANOC web site and social media program, disagreed. "CTV was the host broadcaster so we (VANOC) did provide some support to them. However, in terms of their strategies and connecting with their audience, they did their own thing. We weren't competing with CTV because they were serving the Canadian audience covering the Canadian team, and we were serving the global/international audience."

\section{Television coverage}

According to a VANOC news release (Feb. 28, 2010), television coverage of the Olympics was extensive and viewing statistics showed that many people tuned in. Over the course of the 17-day event, VANOC stated that an estimated 3.5 billion people worldwide watched the Games on television, which included 33.1 million Canadians or 99 per cent of the population. However, public opinion research estimates that the number of Canadians who watched or attended at least one of the events or competitions during the 2010 Olympic in February was closer to 89 per cent (Decima Research, May 25, 2010).

Olympic rights holding broadcasters covered the Games on more than $300 \mathrm{TV}$ stations and on more than 100 websites worldwide, which represented 
approximately 24,000 hours of coverage. This was said to be a 47 per cent increase in global television coverage since the Torino 2006 Olympic Winter Games.

Television coverage of the Games by the broadcast media consortium was provided in 22 languages to ensure Canada's diverse ethnic populations had access to Games coverage, including Bangla (ATN); Cantonese (OMNI); Cree (APTN); Dene (APTN); English (CTV, Rogers Sportsnet, TSN, OLN, APTN); French (V, RDS, RIS Info Sports, APTN); Gujarati (ATN); Hindi (ATN); Inuktitut (APTN); Italian (OMNI); Mandarin (OMNI); Mechif (APTN); Mi'Kmaq (APTN); Mohawk (APTN); Ojibway (APTN); Oji-Cree (APTN); Polish (OMNI); Portuguese (OMNI); Punjabi (ATN and OMNI); Tamil (ATN); Ukrainian (OMNI); and Urdu (ATN) (CTV news release, Nov. 16, 2009). In addition to CTV and Rogers Sportsnet, television coverage was also provided on the following consortium member networks: TSN; V (French); RDS (French); RIS Info Sports (French); OMNI (multicultural); OLN (adventure coverage); ATN (Asian); APTN (Aboriginal); and MuchMusic (concerts).

\section{Digital coverage}

The 2010 Olympics were also characterized by the large volume of digital information that was transmitted, and the significant number of Canadians who participated in social media activities. In addition to television coverage, the broadcast consortium provided 14 live streams of the Games from the CTV web site, which enabled people to watch whatever they wanted at any time of the day. 
"It was the first truly digital Olympics. If you were connected to the internet, you could get immediate access to results and to video. CTV broadcast every second of the Games on the Internet," said Dinsdale. "People were most interested in watching TV on their computers and mostly, they wanted to watch events that had commentary."

Dinsdale also found that one media vehicle supported or promoted use of another. For example, the more someone would watch live streams of the Games events online, the more they would want to watch, and the more likely they would use other parts of the website - which is a very good model from an advertising point of view in that the more users you have, the more advertising you can sell.

The CTV web site had extensive content, including videos, news and information, event and program information, photos, interactive guides, a medal tracker, fantasy games, audio, athlete, sports and country profiles, live chats, and information about Vancouver and the Games venues.

Dinsdale said that CTV produced many personal stories and "pride stories" about the athletes in an attempt to personalize them so Canadians would know more about the athletes, including their backgrounds, personal stories, likes/dislikes, struggles and successes. "This helped translate into a better appreciation of what athletes go through. People were really interested in this," he said. Online Olympic Games content was fully bilingual, with the majority of print content provided by 
Globe and Mail staff writers, the official national newspaper of the media consortium and the Vancouver 2010 Olympic Winter Games.

Dinsdale said CTV initially estimated that users would access 125 million page views and 17 million video views, a projection that was based on the NBC coverage of the 2008 Beijing Olympics. In the end, CTV greatly exceeded its estimates, and obtained 215 million page views and 28 million video views - almost twice as many as predicted (CTV news release, March 18, 2010). On average, online viewers watched 54 minutes of video each day of the Games, including 14.4 million live HD video views and 14.1 million on-demand HD video views.

VANOC created and maintained a separate web site on the Olympics that was also rich in content, and featured parallel information about the Games, events, athletes and news. As this web site aimed to provide information for an international audience, it did not focus on Canadian athletes or news, as did the CTV site. Users also watched live coverage from this web site, and accessed information about all of VANOC's culture and educations programs, the venues, the Olympic torch relay, and other Olympic information. Essentially, this was the official web site of the Vancouver Olympics.

According to a VANOC news release (Feb. 28, 2010), 275 million visitors in total visited the VANOC web site during the Olympics, compared to the previous record of 105 million visitors set during the Beijing 2008 Games. This worked out to 78 million total unique visitors to the site, with a record of $9,185,306$ unique visits in 
a single day - set on February 24. February 24 was the first day Canada won more than one medal in a single day; in fact Canadian women won four medals in total, including two for bobsleigh and two for speed skating. According to VANOC, the Vancouver2010.com site was visited 85 million times during February from within Canada by more than 50 per cent of the total Canadian population, 70 per cent of which have access to the internet. In addition, 19.1 per cent of North Americans and 4.6 per cent of people worldwide with Internet access visited the site during February 2010.

The web site was a major communications tool, both for providing information but also for getting people to participate in the Olympic experience. Graeme Menzies, who managed the VANOC web site and social media program, said "social media was a contributor to pride. We prepared a web site, Facebook page and Twitter messages. Although you can't make people participate, you can provide the tools and they can choose to contribute. Based on the success of the social media tools at the Olympics, it appears that many Canadians chose to take part in the Olympic experience." He said the web site was of interest to a more mature audience - people who were more used to looking at and going to web sites, but younger people were more likely to go to social media sites. 


\section{Social media}

Menzies argued that the 2010 Olympics were "The Facebook Olympics". The Vancouver 2010 Facebook page was actually started by enthusiastic Games fans then was merged with material created by the VANOC team in 2008 and launched in 2009. At the time of the merger, the Facebook site had about 16,000 fans. The growth of fan membership increased steadily as the Games approached: initially growth was at about 1,000 new fans per week but soon grew to 1,000 a day. Once the torch relay began, Menzies said growth was phenomenal. The initial goal of achieving 500,000 fans by the time the Games began was achieved within hours of the cauldron being lit on February 12, 2010. That number doubled over the course of the Games and by the end of the Games (February 28) there were more than 1.1 million fans. Of these, Menzies said 60 per cent were under 25 years of age, including 27 per cent of users between the age of 13 and 17, and 29 per cent between the age of 18 and 24.

Other social media tools created by VANOC were similarly successful and popular. VANOC had 14,000 followers on Twitter, and sent out a total of 3,320 tweets over the lifetime of the account, half of which were sent during the Games. Menzies said the best use of Twitter was during the last round of ticket sales when people had to go into a virtual "waiting room" to buy tickets. VANOC tweeted every few minutes with information about which tickets were sold out. Twitter was also used during the opening and closing ceremonies, to tell subscribers when certain teams, athletes or performers were on. For example, when Rick Hansen entered the 
stadium, VANOC tweeted information with a link to the Rick Hansen Foundation. During the Games, VANOC tweeted news about a competition with a link to live results, and sent a congratulations message for a medal with a link to the full medal count page.

The VANOC YouTube account had more than one million views over the 17day period, and 100 VANOC-created videos were posted on it. In the pre-Games period, the videos produced were more general. In the torch relay time period, VANOC posted regular updates on the relay. During the Games, they produced daily host videos, which Menzies said was another first for an organizing committee. Every day of competition, VANOC produced a three-minute video summarizing medal results of all countries, providing information about cultural events, and providing clips about spectators to share the spectator experience. VANOC had its own web team of six people producing the video in French and English every day. The videos were also accessible from the VANOC web site.

The CTV YouTube account had 5.7 million video views, from the time of its launch (December 2009) to March 10, 2010 (CTV news release, March 18, 2010) VANOC also developed a mobile spectator guide application that allowed users to access the guide from their mobile phones. This application, which was free, was downloaded more than 1.25 million times, and was rated the top free mobile app in Canada for 10 days during the Games. Instead of spending so much money on spectator guides, VANOC posted the information online. "This was a great tool for 
people because it extended that experience outside of the province, outside of the country. It became a separate branding project. We still get 500 downloads a day, even in October (2010). People still have an interest in the Games," said Menzies. CTV also developed a mobile application that was downloaded 234,000 times, and had 7.8 million page views via mobile device.

Podcasts were created before the Olympics and were available on iTunes for free as well as on the web site. VANOC prepared them during the winter of 20082009 when test events were happening at the venues. The podcasts comprised of short videos about each sport featuring athletes that were potential Olympians. They were also posted on the main Vancouver2010.com web site. "The neat thing is that if you watch that, it's all recorded ahead of the Games with many of the athletes who weren't on the team at the times." Menzies said the podcasts taught people about the sports - how to do the sport, what to wear, what to eat. "We would never have been able to take moving pictures during the Games because of CTV broadcast rights.... They served an educational purpose. In February, they became the top rated podcast download in Canada."

\section{Summary}

Communications and media coverage during the 2010 Olympics was abundant yet complex, given the requirements set out by the IOC regarding how VANOC should communicate and how the CTV-Rogers Olympic Broadcast Consortium, as the broadcast media rights holder, should cover the Games. At times, 
the responsibilities and practices of VANOC and the broadcast consortium seemed to blur as both tried to achieve the same communications goals but from different perspectives. On the one hand, VANOC's goal was to promote the event, the ideals of the Olympic movement, the host city and country, and the sponsors involved - all under the watchful eye of the IOC. On the other hand, the media aimed to do essentially the same thing because they had paid dearly for the right to cover the Games and had a vested interest in their success.

Both VANOC and the CTV-Rogers consortium used a variety of traditional communications/media tools (print, television and radio) and new media practices (internet, social media, video, podcasts) to provide news and information, and to promote the Olympics, build national pride, and strategically control messaging to ensure the Games were a success. This task was completed with a great deal of effort, energy and resources from all involved, resulting in a well-informed Canadian public that felt an increased sense of pride during the Games. It also resulted in an occasionally antagonistic relationship between VANOC and the media, who sometimes felt that VANOC excessively controlled Olympic communications.

Nevertheless, it can be concluded that the volume and variety of media sources and communications messages did successfully engage Canadians to participate in the Olympic experience in one way or another, which ultimately lead to increased interest, pride and a sense of being part of something important. 


\section{Chapter \#5: Media Scan}

A media scan of newspaper coverage during the 2010 Olympics attempted to determine whether the media reported objectively, what issues were reported, and how they were covered. Given the broadcast rights based approach to media coverage at the Olympics, as discussed in Chapter \#4, this media scan also examined whether the media coverage reflected any formal association the newspapers had to the Olympics.

The study reviewed two newspapers to document and analyze issues, trends and coverage of the Olympics. The Vancouver Sun is a local newspaper without direct links to the Olympic broadcast consortium but is the newspaper of the host city, and the Globe and Mail is a national newspaper and part of the conglomerate that also operated the broadcast consortium. The review was done to detect trends and differences between local and national coverage, and to distinguish the difference in coverage between a newspaper that is part of the broadcast consortium - and unofficially tasked with promoting the Olympics - and one that is not.

To get a snapshot of media coverage during the Olympics, the review examined articles published in both newspapers on four specific days:

1. February 13 - the day after the opening ceremonies and the day after Georgian luger Nodar Kumaritashvili died in training;

2. February $\mathbf{2 0}$ - in the middle of the competition and represents the point at 
which there appeared to be a shift in public sentiment from concerns about glitches to feelings of pride about Canadian athletes' achievements;

3. February 25 - near the end of the Games as Canadian athletes continued strong performances amid growing anticipation of the men's hockey gold medal final game; and

4. March 1 - the day after the closing ceremonies and that hockey game.

The media scan examined the stories published on those days to determine: type of content/coverage; whether stories were positive, negative or balanced; what issues were reported and how they were reported; what opinions or viewpoints were expressed, if any; whether there were any obvious relationships between media (for example, was one member of the consortium promoting another?); whether stories either discussed Canadian pride or promoted it; and any other relevant factors. The scan reviewed stories published in all sections of the newspapers, including the sports sections, the news/features sections, and a special daily Olympic section published by the Globe and Mail. While the Globe and Mail published every day, including Sunday (which it does not normally do), the Vancouver Sun did not publish on Sundays during the Games.

February 13, 2010 (Day \#2) media scan:

Vancouver Sun: On the second day of the Olympics, the Vancouver Sun published many stories about the Olympics, with much of the focus on the tragic 
death of 21-year-old Georgian luger Nodar Kumaritashvili the previous day. The articles on the death expressed sympathy to the luger's family and provided personal details about the luger's life and athletic career. Stories also aired criticism by officials of the luge course and questioned its safety, noting that after learning that Kumaritashvili had died, the chairman of the International Luge Federation had asked if the men's luge event should be cancelled or postponed because of safety concerns (Botchford A12). The paper quoted the Georgian luge coach on several occasions talking about the high level of difficulty of the course, and that the course was 'bad' (Bell A12).

Several stories ran criticisms about the design of the track: "Why was the luge track with the record vertical drop running $20 \mathrm{~km} / \mathrm{h}$ faster than it was designed to be? How could there be exposed steel posts a few feet off an outside curve where athletes are travelling $145 \mathrm{~km} / \mathrm{h}$ ? Might Canada, in its zeal to protect its athletes' home-course advantage, have inadvertently contributed to the likelihood of crashes involving lower-ranked athletes who hadn't had sufficient opportunity to train on such a wild, fast run?" (Cole A6).

One article noted that the posting of the video of the luger's death on YouTube and Twitter messages about the death enabled people to get the information quickly but questioned whether it was appropriate, asking whether it was "death porn or just sharing the latest news?" (Shaw A12). 
In many cases, the death was treated as a strike against VANOC, with stories noting that "our first thoughts were not about him, but about us... For seven years, the people running the Vancouver 2010 Games had done almost everything right. Venues were built on time and mostly on budget. Nobody's nephew got a lucrative Olympic contract for anything. There were no disappearing tickets, no blockades by First Nations, no siege of the torch as it was carried to every cranny of Canada... It's a tragedy that Kumaritashvili died, and nearly as great a shame his host country will forget him as soon as Canada wins something." (Maclntrye E1). The Sun quoted VANOC's John Furlong frequently saying that Canadians were heart-broken and deeply saddened by the tragedy. $10 C$ President Jacques Rogge expressed condolences to the luger's family.

Other than the luger's death, little controversy was aired. One very short article reported on a Vancouver police officer relieved of his duties because of drinking (Pynn A16). Another noted that the crowds in Vancouver were not hampered by BC Place security, as was expected (Culbert A13). A short piece aired discontent at parking price increases to $\$ 95$ a day at two downtown parking lots (Sinoski B3). Several made mention of the poor weather, noting that there was little winter at the winter Olympics.

Pride and optimism emerged in several stories describing the feelings of Canadians as the Olympic flame entered the Olympic stadium, during the torch light relay, and about athletes at the events. Several stories described the torch relay, 
quoting those who stated it had positive impact on the pride of Canadians. The paper also noted significant optimism: "This is not Vancouver or even B.C. any more. For the next 16 days it's the land of make-believe. As the emotional response of Canadians from coast to coast to coast indicated, as the enthusiasm that greeted the longest torch relay in history proved, from Nunavut to Newfoundland, from Cape Breton to Alert Bay, across this great land, we are ready to believe." (Mulgrew A4) Another story stated that "On home soil, it turns out, an Olympic flame has a magical alchemy on most of us. It sparks a sense of patriotism and unity, no matter how hard you might try to resist it. I suspect that many of the people who profess to loathe the Olympics still sense the palpable pride that seems to emanate from the crowd who gather to see the torch." (Cernetig A10)

Many Sun articles focused on athlete profiles, personal stories and predictions of results or success, providing a significant amount of background information about the athletes and their sports. Some mentioned winning medals and whether Canadian athletes were feeling pressure. Other stories focused on events to be held in Vancouver, the opening ceremonies, and what was involved in organizing the Games, and were largely positive and uncritical of the Games. A few pieces highlighted the success of the Aboriginal Tourism Association, and were optimistic about future business opportunities. (Pemberton A17)

Globe and Mail: The Globe and Mail had equally extensive coverage, however the focus was not on the death of the Georgian luger. In fact, only two short articles 
made reference to the accident as compared with more than a dozen in the Vancouver Sun. Instead, most Globe and Mail articles focused on athletes, schedules of events, television viewing times, and the opening ceremonies. A largely positive article about the opening ceremonies stated "VANOC lived up to its reputation for running a tight ship, directing an estimated 100,000 people into the Olympic stadium with military precision even as throngs of protesters packed the streets." (Armstrong and Stueck A4)

Several articles focused on the broadcast consortium, including a history of Olympic broadcast rights, the importance of advertising to broadcasting costs, and the relationship between the upcoming gold medal hockey game - which Canada was expected to win - and advertising revenue. Keith Pelley, president of the Canada's Olympic broadcast consortium, said "We were very fortunate to be selling the biggest event of this century. I think we would have felt [the economic slump] a lot more if the Games weren't in Vancouver... We just noticed that the interest has just continued to soar with the torch relay, so it's really given us a lot of confidence, with still some advertising inventory still left to sell." (Duhatschek V23)

One article in the Globe about broadcast coverage of the Games included overly positive almost promotional quotes from the head of the digital media group of the consortium: "You'll have the best professionals bringing you every sport while you're personalizing your Olympic experience from your couch. On TV, we'll serve you with the live programming Canadians expect from an Olympics. But the Games 
will also be on mobile, they'll be online, they'll be on your portable device - even on X-Box. We'll serve across 15 different outlets for the Games." The article read very much like a news release, and directed viewers to digital media produced by the consortium (Dowbiggin V20). Another article, which appeared to be promoting the consortium and its journalists, focused on the talent of journalists who would be working for the consortium, including Brian Williams and Rod Black, saying: "Williams prides himself on thorough preparation and studies his subjects incessantly." (Christie V16).

An editorial about VANOC and the Own The Podium program called it a model for national projects and opined that investment in sport was necessary, stating "The Canada of the 21st century can emerge in the next two weeks: confident, risk-taking, at the leading edge. And dreaming big. There may be no greater legacy from the Vancouver Olympic Games that begin in earnest today." (A30)

Few articles carried criticism of the Games. Some negative coverage included an article about various city businesses and restaurants working late at night to prepare for the crowds during the day, and quoted a businessman saying he's not crazy about the 24-7 work schedules the Olympics have foisted on restaurants. (Armstrong A8) Only one short piece mentioned that the Vancouver police officer was relieved of Olympic duties because of alcohol. (Matas \$4) 
February 20 (Day \#9) media scan:

Vancouver Sun: Coverage in the Vancouver Sun on the ninth day of the competition - essentially the mid-way point - was extensive and varied, with a split between positive stories about athletes, results and Vancouver attractions during the Olympics, and negative stories about problems with the Games and OTP.

A few stories continued to address the problems experienced during the Games, including one called "'Glitch Olympics' tag starts to fade; Sunny weather appears to melt criticism", which detailed all the problems at the Olympics to date, noting that the Games media nickname "Glitch Olympics" had abated somewhat. (Lee A6) Another story, entitled "Glitches don't dampen super-fan experience; Not even hypothermia can stop a hardcore Olympics booster from cheering on athletes in her home city" profiled an Olympic fan defending the Games, quoting her saying she blamed much of the Olympic-bashing on the prevalence of social networking sites such as Twitter and Facebook. (Hansen A11) A third story stated that athletes were puzzled by negative international press, and instead talked about 'how beautiful it is and what a great Olympics it is.' (Ziemer E11)

Several articles addressed OTP, including one called "Just about time for a Code Red on that Own the Podium thing, eh?" in which the reporter wrote that the program had so far not yielded the results it promised, and might not achieve them. Another critical story provided more balance as it quoted a COC official saying several of those athletes winning fourth places hadn't been medal hopefuls, so it proved that 
the OTP program was developing talent as well as producing results. A story about skeleton athlete Mellisa Hollingsworth finishing a disappointing fifth place carried her comments: "I feel like l've let my entire country down... VANOC and Own the Podium and my entire federation. They've done so much for me." (Hall E3). One story carried the headline “Don't bet the mortgage on 'Own the Podium'; Grandiose expectations for home Olympic Games might need to be scaled down just a little", and sarcastically commented that "Canada is not going to own the podium at these Games... but later stated that "We know that in the last four or five days of the Games, we probably have a nine-to-11 medal potential; that's our wheelhouse. So we're still on track, we're still ahead of where we thought we would be, where we planned to be at this point." (Cole E4)

Some stories addressed the pressure on athletes to win. A few focused on the failure of the alpine ski team to live up to expectations, including Eric Guay's near medal. The Sun quoted coach Paul Kristofic saying "For me it's frustrating. It really pisses you off that the guys couldn't come up with it when the whole world is watching. I feel a sense of letdown to the people who back us. It's frustrating to come up short." (Kingston E6)

An editorial noted that the difference between gold and no medals is extremely small, and described Jeremy Wotherspoon's inability to win Olympic medals despite success elsewhere. (A22) A more positive story headline read "Jon Montgomery to the rescue; Skeleton racer's gold medal lifts sagging spirits on 
disappointing day for Canada" but went on to state that these Olympics were "threatening to become the Hard Luck Games for Canada as the marquee athletes not only are failing to own the podium, they're having trouble scraping together a down payment." (Mulgrew A4)

Globe and Mail: The Globe and Mail coverage was less extensive than the Vancouver Sun. Some stories reported on the results of the competition, highlighting Jon Montgomery's gold medal win and Mellisa Hollingsworth's disappointing fifth place finish. Others focused on results including hockey scores and the lack of Canadian medals in alpine skiing and speed skating.

An article entitled "Tories push patriotism - and possibly votes" described a video that included past-Olympic medal-winning skier Conservative Senator Nancy Greene comparing Canadian athletes to "our strong leaders," Stephen Harper, and stating "With our strong leader, Canada will continue to compete with the world's best." (Taber A9) Other articles focused on event schedules and celebrities seen at the Games.

\section{February 25 (Day \#14) media scan:}

Vancouver Sun: Coverage in the last week of Olympic competition focused predominantly on Canadian athlete performances and hockey. An article about the women's bobsleigh victories was entitled "Canada owns the podium in women's race; Humphries and Moyse claim the gold, while teammates Upperton and Brown 
take the silver", and stated that "Canada might not own the podium at these Olympics, but they certainly rented the prime spots for Wednesday's flower ceremony." (Hall D7) Another story focused on the future of OTP, reporting that the Canadian Olympic Committee had asked the federal government for an additional \$22 million. It also quoted Chris Rudge, the CEO of the COC, stating that Canada would likely not "own the podium" at the 2010 Games despite its strong showing of gold medals. (Lee A8)

Story headlines became more animated and confident, including the following samples: "A great O Canada day; Medals in speed skating and bobsleigh, and a rousing men's hockey win over Russia", "Boiling Canadians burn shocked Russians; Bulldog line renders Ovechkin useless, while hungry offence rolls over rivals like a tsunami" and "Canada breaks a 50-year-old Russian curse; But the team still has their eyes on the ultimate prize -- a gold-medal win on home ice."

A growing number of articles highlighted Canadian pride, including one entitled "Furlong 'stunned' at level of patriotism; VANOC CEO expected Canadians to embrace the Olympics, but admits the size of the crowds has been shocking". It quoted Furlong extensively, saying "everybody was underestimating the people of this city, and I think the people of this city are saying, 'Stand back, we're here'... When we declared these to be Canada's Games... there was some violin-playing going on, that people said that isn't going to happen, the country is too big... I think people are being left behind with something very powerful and human and uplifting, and I 
hope that people will look back and say the people of this country took this to a different place." (Lee A8)

Stories of personal pride included one about Ashleigh Mclvor's gold medal in skier cross, which described several people's positive reactions to her win (Culbert A17). A story about Joannie Rochette's strong performance in the short program further built the emotional story unfolding of her performance following her mother's sudden death in Vancouver just prior to Rochette's competition.

An editorial noted that some Canadians were growing annoyed with official Olympic boosterism, and had complained or joked about the "haughty" Canadian Olympic team slogan, Own the Podium. The article questioned the Olympics "believe" campaign, and asked what Canadians were being urged to believe? It stated that for months, Olympic broadcasters have been repeatedly and explicitly urging us to "believe" the Games will "unite the country" and that "Canadian athletes can -- and will -- own the podium." (Todd A17)

Other articles profiled athletes, provided speculation about results, and discussed the future of ski jumping and the Olympic facilities. The high interest in hockey was evident from the number of stories that debated the outcome of several games. One article predicted the upcoming excitement if Canada made it to the men's hockey final, stating "This city and this country is going to come to a stop and everybody will be watching Friday [semifinals] and especially Sunday [final], if we get 
there... When it comes to the Winter Olympics for Canadians, if it goes right in hockey, it goes right for the Games as a whole." (Dheensaw B2)

Globe and Mail: Coverage was somewhat less extensive than the Vancouver Sun and focused on different stories. Entitled "Cool, detached, self-satisfied Vancouver gains momentum", one story provided details about the celebratory atmosphere in Vancouver during the Olympics and quoted Vancouver mayor Gregor Robertson saying "Vancouver was slow to warm to the Olympics, with pre-Games polls showing widespread skepticism that they would be worth the cost. Few are saying that now... Vancouver has always had the ingredients to strut its stuff on the world stage, but there has been a tendency in the past to stifle or set them aside "in a modest, West Coast way. The Olympics have uncorked our passion and pride..." (Mickleburgh S1)

In an article entitled, "How these Olympics should end", the reporter complemented Canadian athletes on their performances, and listed the things that should happen at the Olympics, including Joannie Rochette should win a medal; Canadian women curlers should win gold, everybody should realize that the emphasis on the men's hockey team was a big mistake, and other less serious, more funny wishes. (Doyle R3)

A few stories focused on the future of OTP, including one that stated "As predictable as Vancouver rain, Ottawa warns it will just say no to more funding for Own the Podium.... The Canadian Olympic Committee should know by now that the 
feds put money up front to try to ensure we're not an embarrassment at Games we host and, as they end, so does any enrichment funding. It happened after 1976 (we had Game Plan) and it happened after 1988 (we had Best Ever '88)." (Reid A16) Another article about OTP predicted that neither the government nor sponsors would continue supporting elite training programs after the Games, while stating that it is necessary to do so. (Matas and Waldie A7)

The paper also carried several stories about Olympic hockey, including several about women's hockey. Another profiled Ashleigh Mclvor as the Olympic Golden Poster Girl.

\section{March 1 media scan:}

Vancouver Sun: Media coverage the day after the Olympics finished was positive, congratulatory and nostalgic. Several Vancouver Sun stories summarized the Olympic experience and the shift from early criticism to the positive end to the Games. There was plentiful praise for VANOC: "Despite a bad misstep on the death of Georgian luger Nodar Kumaritashvili, VANOC responded well to most of the complaints levelled against it (and wisely did not rise to the twits in the British press who hurried to christen this the worst Games ever)." (McMartin A6) Headlines on stories were very complimentary, including "Early critics among world media change their tune; 'Boos' turn to 'oohs' as Vancouver gets gold for Games." (Belet A13), and "Furlong moved more than a mountain, he moved a country." (Lee A5). 
Several articles addressed pride and what "being Canadian" meant: "there was something greater afoot. It was something you saw in the streets, and something expressed in the closing ceremony. Part of it was the outsized displays of nationalism, which is to be expected, given the setting. But more than that was the evidence that this is a country now more willing to laugh at itself." (McMartin A6). Another stated "these Games will leave us with more than a few memories. We will recall the highs and lows, the tragic death on a training run of a Georgian luger, and the emotional performance of a Montreal figure skater mourning her lost mother, winning bronze and then carrying the Canadian flag because, as Joannie Rochette had said earlier on Sunday, 'Canada carried me.' We'll remember those three million pairs of mittens. And that ours was the highest viewership ever of a Winter Olympics. That half a million people came to Vancouver's downtown street party. That we owned the podium." (Fralic A5) Yet another stated: "With a few blasts of national fervour, the likes of which few Olympics have ever experienced, Canada's extraordinary 'Patriot Games' were coming to a closing crescendo here in Vancouver with the host nation already safely able to wallow in the glory of topping the medal table." (Belet A13)

Several articles addressed the economy and post-Olympic future for Canada and $\mathrm{BC}$, including one which discussed the impact of the Games on the $\mathrm{BC}$ economy and stated "If the Olympics have taught us anything, it's that large, complex projects can be accomplished within a relatively short time when the political will is there. Setting ambitious goals should not be restricted to sports: Let's create the type of 
socially, environmentally and economically just society that most British Columbians want for themselves and their children." (Ivanova A17)

Several articles highighted Canada's record number of gold medals and the role of OTP, quoting COC President Michael Chambers saying "I don't think we set the wrong target at all. By setting the target that we did, we won [14] gold." (Culbert A4) Another compared the failure of the Canadian alpine ski team to succeed with the failure of the Austrian team: "But as shutouts go, Canada's was nothing compared to what happened to the vaunted 'Wunderteam.' For the first time since 1936, no man from skiing-mad Austria won an alpine medal." This comparison appeared to suggest that failure wasn't as bad if shared with another talented team that was also expected to win. (Kingston C13) The headline on another story echoed support for OTP: "Record Olympic gold-medal haul is frosting on the cake; No one could have predicted Canada's fantastic second week, but Own the Podium program shows its value in 72 top-eight finishes." (Cole $A 3)$.

The gold medal hockey game received coverage - all positive - with the focus on Sidney Crosby's goal and the resulting explosion of pride in the stands and across Canada (Traikos C6) Other stories focused on medals and results including a complimentary one about Jasey-Jay Anderson's gold medal in snowboarding (Wolfe C11), the curling win, Devon Kershaw's Nordic skiing medal, and the unfortunate fate of blind skier Brian McKeever, who was not selected to represent Canada in the men's 50-kilometre classic ski race. 
Globe and Mail: Positive media coverage also focused on pride, Canadian achievement, the success of the Games, and the final gold medal hockey game. Several stories addressed how Canadians had changed because of the Olympics. One story entitled "A golden end to Games that altered a nation," speculated that "You will hear a lot of that in the coming days - how these Olympics changed us, gave us more confidence, altered the outlook of ourselves. No one is sure how this newfound self-belief, buoyancy, will ultimately manifest itself. My guess is it will likely happen in a million barely distinguishable ways. And a few grand and obvious ones too." (Mason A8) One story concluded that the end was "a perfectly Canadian finish" (Janisse A18), while another stated that "Canada swaggers to centre stage at BC Place" (Mickleburgh A7) . A story entitled "Olympic Centre rocks with true patriotic love" discussed the enthusiasm and pride displayed at the curling final. (Weeks E10) Several articles congratulated VANOC for a job well done in several articles, including one that stated: "To roars from the crowd, torchbearer Catriona LeMay Doan successfully lit the flame. It was yet another example of VANOC's ability to respond well when difficulties arose, a key feature that made these Games so successful." (Mickleburgh A7)

"The storybook ending to a storybook Games" was how one Globe editorial described the final hockey game, then continued with support for OTP: "with the right kind of private and public commitment, to fund our athletes and to maintain this new culture, future generations will deliver the performances, the stories and 
the medals, showing that the Vancouver/Whistler Games were a turning point, that they were truly Canada's Games." (A18) An article entitled "Vindication for Own the Podium" discussed the merits of the program, quoting departing OTP president Roger Jackson requesting more funds for the future of the program, and $I O C$ President Jacques Rogge saying "There has been a lot of criticism [about OTP]. But you can legitimately ask whether there would have been any gold medals without Own the Podium." (Waldie A2)

An opinion piece by Liberal leader Michael Ignatieff suggested that the Olympics brought the reality of global competition home to Canadians. He wrote "The Games taught us that we need to focus on what we do best and then be unsparingly disciplined about continuing to be the best. Investing in our best people is not elitist - it encourages the rest of us to improve what we do.... the Olympics taught us to invest in excellence and invest for the long term... Most of all, the Games revealed the deep longing of all Canadians for more moments like this, when we feel we are one great people, from coast to coast to coast, one team undivided, at one with our dreams and with each other. When we feel like this, we truly own the podium." (A19)

Several stories addressed the economy and how Vancouver will rebound from the Olympics, including one that stated: "What concrete economic benefits can Vancouver expect in the first year or so after the Olympics? We're expecting a significant increase in jobs and job performance and employment opportunities 
directly associated with the Games. There are a number of key sectors that we're anticipating that job creation in, primarily clean tech and green-enterprise technologies, as well as in media - live action, digital action and digital media sectors." (Barton S1)

\section{Summary}

Based on this informal survey, it is clear that coverage in the Vancouver Sun and the Globe and Mail during the Olympics differed somewhat, but both newspapers provided balanced coverage with slightly more positive than negative stories. The Vancouver Sun tended to have longer, feature-length stories about the athletes, the competition, the events in Vancouver, and the criticism of the hosting and operations of the Games, however the level of depth in both newspapers' stories was similar. The Sun focused more on the death of the luger than the Globe did, and the Globe published more stories on media-related issues that the Sun did.

Given that the Globe had a formal association with the Olympic broadcast consortium, it was somewhat surprising that it didn't have more coverage than the local paper, although it may have been hurt by timing, given that there was a threehour time difference between Vancouver and Central Canada and that detailed coverage of evening events would have been difficult as they often didn't end much before midnight EST. However, as the Olympics were in Vancouver, it is not surprising that the newspaper of the host city would have the most coverage. In general, both newspapers covered local and national issues to the same degree. 
Coverage by both newspapers showed similar patterns, starting with more negative coverage at the beginning of the Games then transitioning to more positive coverage as the Canadian athletes achieved successes. In the first week, reporting repeatedly highlighted the various difficulties experienced during the Olympics, including the death of the luger, the fence that kept the public at a distance from the Olympic flame and made it impossible to shoot pictures of the flame, the dysfunctional ice resurfacing machines at the Richmond speed-skating oval, the confused bus drivers and broken down buses, the malfunction of one of the pillars rising from underground at the opening cermonies, and the mild weather. VANOC was blamed for many of these issues.

As the second week of the Games started, the weather cleared, Canadian athletes started to win medals, and coverage became both more positive and there was more mention of pride and achievement. Several articles throughout the week discussed the positive merits rather than the negative connotations of the Own The Podium program, and made repeated links between the success of Canadian athletes and the pride felt by Canadians. As the medals increased, the frequency of stories about pride increased.

Given the high interest among Canadians in hockey, both newspapers published more articles about hockey than any other sport. Predictions of success and game talk dominated these articles. Opinion was split about whether it was imperative that Canada win the final men's hockey game for Canadians to feel proud 
of their team. Even though the Globe and Mail was a member of the Olympic

broadcast consortium and might have been expected to report on the Olympics with more boosterism, this scan of the coverage did not reveal this to be true. 


\section{Chapter \#6: Public Opinion Research}

There were many goals set for the 2010 Vancouver Olympics by governments, non-governmental organizations, private businesses, athlete organizations, athletes, and the general population. These goals focused on sport development, tourism, environmental sustainability, social development, arts and culture, economic development, employment and business development (Price Waterhouse Coopers Framework Report, 2010, p. 1). While many of these goals differed, a common thread was the desire to increase the level of national pride among Canadians and build a stronger Canada whose spirit is raised by its passion for sport.

Many scholars agreed that the Olympics could increase national pride, especially for the host country, however they did not have clear agreement on how pride could be measured, what degree of change in pride would be considered significant, and what specific factors could lead to a change in pride. Scholars also did not definitively determine what effect an increased sense of pride could have on a country, and what its "value" or "worth" was. In essence, what good does it do to increase national pride in a country, who benefits, and why is national pride important?

In this chapter, the collective views of Canadians regarding the effect of the Olympics on Canadian pride were examined through the lens of public opinion polls, which asked Canadians about their experiences and feelings before, during and after 
the 2010 Vancouver Winter Olympics. Given that pride is a subjective term, the public opinion research attempted to provide qualitative or quantitative information on how the Canadian population experienced pride, whether there was a change or shift in pride experienced after the Olympics, and what effect pride had on individual Canadians, their communities, and the country as a whole. Public opinion polls helped to paint a realistic picture of what Canadians said and felt about pride, and were used to determine if there was a significant shift or change in national sentiment resulting from the Olympics.

This chapter examined the results of approximately 25 public opinion polls that were completed over the last year to directly address issues, ideas, experiences and opinions of Canadians regarding the 2010 Vancouver Olympics. The research was conducted by several organizations, including Angus Reid, Ipsos Reid, Harris/Decima, Decima Research, Nanos Research, Innovative Research, Ekos Research, and Robbins SCE Research. Research was completed either independently or was commissioned by Heritage Canada, Canadian Press or VANOC. Several of the studies were also part of a series that tracked trends across Canada, in British Columbia, and in the host cities of Vancouver and Whistler. The following chapter summarized key findings and common threads in this research as it related to the question of the relationship between the 2010 Olympics and Canadian pride.

Before the Olympics began, Canadians had expectations of how interested and excited they would be, whether they would watch or attend events at the Games, 
what the outcome of the Olympics would be with respect to medals won, and whether they expected to be proud to be Canadian during and after the Olympics. The following summary of findings looked at what Canadians collectively said about these factors, and whether there was a shift in their expectations, feelings and/or experiences.

Interest, excitement and attendance at the Olympics

Assuming that national pride can take many shapes, and can be distinguished on the basis of intensity of the emotions involved (Van Hilvoorde, Elling and Stokvis 89), an examination of excitement levels and interest would be useful with a view to gauging how interested Canadians were in the Olympics, whether they watched or attended the events, and whether they were genuinely excited.

\section{Expectations before the Olympics started}

One year before the Olympics opened (from Sept. 2009 to Dec. 2009), excitement levels across Canada remained constant with 44 per cent of people reporting that they were excited while 54 per cent were not excited. Three months before the Olympics, excitement rose to 62 per cent (Angus Reid, Nov. 20, 2009). When asked about their intentions to watch the Games, 18 per cent of Canadians said they would watch the Games every day; 43 per cent planned to watch events that interest them; 24 per cent didn't plan to watch any events but expected to see some of it; and 14 per cent said they would not watch the Olympics (Innovative Research, Jan, 2010). 
In British Columbia (BC), excitement levels rose during the pre-Olympic period, but continued to be behind the national average: 29 per cent of $\mathrm{BC}$ residents reported they were excited in September 2009, while 35 per cent were excited in December 2009 (Innovative Research, Jan. 2010). In Vancouver and Whistler, 79 per cent of respondents said they would follow the Vancouver Winter Olympics "very closely" or "moderately closely (Angus Reid, Feb. 11 2009).

\section{Expectations during the Olympics}

Nationally, despite original expectations that 61 per cent of Canadians would watch the Games, in fact 79 per cent of Canadians said they watched or attended the Olympic Opening Ceremony, 70 per cent said they watched or attended the Olympic Closing Ceremony, and 89 per cent said they watched or attended at least one of the events or competitions during the $\mathbf{2 0 1 0}$ Olympic in February. Canadians more likely to say they watched or attended the Games included residents of the Atlantic provinces (93 per cent), Canadians 18 to 55 years old (90 per cent), households earning more than $\$ 80,000$ (92 per cent), Canadians with a university education (93 per cent), Canadians with a disability ( 85 per cent), and Canadians with internet access (89 per cent) (Decima Research, May 25, 2010).

In $\mathrm{BC}$, building excitement translated into more $\mathrm{BC}$ residents following the Games than first anticipated and more than the national average: 83 per cent followed Games very closely or somewhat closely while only 18 per cent said they did not follow the Games closely or at all; 87 per cent of $B C$ residents watched the 
closing ceremonies (Ipsos Reid, March 2, 2010).

In Vancouver and Whistler, residents became more enthusiastic following the first few days of the Winter Olympics (Angus Reid, Feb. 18, 2010), and 79 per cent said they followed the Olympics "very closely" or "moderately closely", while 50 per cent said they were excited about the Olympics and that the Games were not an inconvenience to their day-to-day lives, as first expected.

Enthusiasm about the Olympics reached an all-time high in the final online overnight poll within 24 hours of the closing ceremony. A large majority of BC residents ( 86 per cent) were very/somewhat excited about Olympics, compared with 73 per cent one week before, and 78 per cent two weeks before (Ipsos Reid, March 2, 2010).

\section{Pride and the Olympics}

The public opinion research supported the view that a sporting event like the Olympics provided an opportunity for individuals to publicly express their commitment to Canada, and feel proud of themselves for hosting the Olympics.

Before the Olympics started, Canadians believed the most positive impact the Olympics would have would be on tourism ( 92 per cent), on national pride ( 88 per cent) and on Canada's image abroad (87 per cent).

Comparing studies completed in three different time periods, the perception that the Olympics would positively impact national pride increased from 82 per cent in June 2007; to 83 per cent in February 2009, to 88 per cent in February 2010. The 
most noteworthy trend was among Quebec residents. In 2007, 77 per cent of Quebec residents felt the Games would have a positive impact on national pride in all regions of the country, while in 2010 , that number increased to 87 per cent (Decima Research, Feb. 2010).

During the Olympics, the percentage of Canadians who felt the Olympics would have a positive impact on national pride during the Olympics was further broken down into the following (Decima Research, Feb. 2010):

- By region: BC (75 per cent); Alberta (89 per cent); Manitoba/Saskatchewan (86 per cent); Ontario (86 per cent); Quebec (77 per cent), Atlantic ( 85 per cent) thought the Olympics would positively impact national pride;

- By gender: 79 per cent of men and 85 per cent of women thought the Olympics would positively impact national pride;

- By age: 86 per cent of 18-34 years olds; 82 per cent of 35-54 years olds; 78 per cent of 55 and older thought the Olympics would positively impact national pride;

- By income: 80 per cent of those earning less than $\$ 60,000 ; 86$ per cent of those earning $\$ 60,000-80,000$; and 91 per cent of those earning over $\$ 80,000$ were more likely to believe the Games would have a positive impact on national pride;

- By language: 83 per cent of English-speaking Canadians versus 78 per cent of French-speaking Canadians thought the Olympics would positively impact 
national pride (Decima Research, Feb. 2010).

\section{Achievement, pride and unity}

The majority of Canadians (58 per cent) agreed with the statement that "these Winter Olympic Games will be remembered as one of the greatest Canadian achievements," and 77 per cent believed that "these Winter Olympic Games are doing a lot to unite Canadians" (Canadian Press/Decima, Feb. 22, 2010).

An Ipsos Reid study noted that Canadians' sense of pride and confidence in the country's abilities had increased in several ways, likely as a result of the tremendous showing at the Olympics, both by athletes and organizers (Ipsos Reid, March 8, 2010):

- 63 per cent agreed that "when Canada speaks the world takes notice", an increase of 13 per cent from 2009;

- 88 per cent agreed that "Canada plays a positive role in international affairs", an increase of 5 per cent from 2009;

- 88 per cent agreed that "people in other countries look to Canada as an example", a 5 per cent increase from 2009;

- 88 per cent agreed that they were "patriotic", a 4 per cent increase from last year;

- 93 per cent agreed that "Canada is a desirable destination for international tourists", up 3 per cent from 2009;

- 90 per cent agreed that they were "proud of their country", an increase of 2 
per cent from 2009;

- 90 per cent agreed that if they "could choose to live in any country in the world" they would "choose Canada", a 2 per cent increase from 2009;

- 83 per cent agreed that "Canada's Olympic athletes inspire" them and members of their family, an increase of 16 per cent from 2009.

\section{Expressing pride}

The Olympics provided ample opportunities for people to display their pride through the frequent use of national symbols, such as the national flag and the national anthem (Cho, 2009, p. 360).

Since this was Canada's moment to shine, studies found that Canadians weren't shy about putting their pride on display. Many Canadians showed their pride for their nation in various ways. For example, four in ten ( 40 per cent) agreed they would fly/display the Canadian flag during the Olympic Games, and one in three (34 per cent) agreed they would wear Olympic/Canada clothing during the Olympic Games. When asked whether "there was too much Canadian nationalism on display during the Olympics", 71 per cent disagreed (Ipsos Reid, Feb. 23, 2010).

\section{"Being Canadian"}

If we agree with Will Kymlicka that "being Canadian" is about being a "good citizen of the world" (359), the public opinion research about Canada's global image is important.

After the Olympics, 75 per cent of all Canadians said the Olympics helped 
Canada's image around the world. Broken down, this included: Atlantic Canada (85 per cent), Alberta (84 per cent), BC (78 per cent), Ontario (77 per cent), Prairies (77 per cent), Quebec (61 per cent). However, of these, 79 per cent of English-speaking Canadians versus 57 per cent of French-speaking Canadians agreed that the Olympics helped Canada's image (Innovative Research Group, March 2010).

In another study, respondents were asked the extent to which they agree with the following statement: "Hosting the 2010 Olympic and Paralympic Winter Games increases your sense of pride about being Canadian". Two-thirds of Canadians agreed; 21 per cent were neutral, while only 12 per cent disagreed (Decima Research, Feb. 22, 2010).

\section{Sense of.Belonging}

Nearly one half ( 45 per cent) of Canadians said they belonged first and foremost to their country, while significantly fewer said they belonged to their town/city (20 per cent), province (19 per cent) or the world (16 per cent). But these numbers changed slightly depending on what province a person lived in. For example, 57 per cent of Ontarians were most likely to say they belonged first and foremost to their country, followed by those living in Saskatchewan and Manitoba (50 per cent), British Columbia (48 per cent), Alberta (44 per cent), Atlantic Canada ( 40 per cent) and Quebec ( 26 per cent). Quebec residents ( 38 per cent) were most likely to say they belonged first and foremost to their province, while that feeling wasn't as strong in Atlantic Canada (33 per cent), 
Saskatchewan and Manitoba (29 per cent), Alberta (22 per cent), British Columbia (13 per cent) and Ontario (5 per cent) (Ipsos Reid, Feb. 23, 2010).

British Columbians (21 per cent) were most likely to say they were first and foremost citizens of the world, while Albertans (16 per cent), Ontarians (16 per cent), Quebec residents (15 per cent), Atlantic Canadians (10 per cent) and residents of Saskatchewan and Manitoba ( 9 per cent) were less likely to say so (Ipsos Reid, Feb. $23,2010)$.

Quebec residents seemed disappointed by a perceived lack of French language and culture during the televised opening ceremonies (Angus Reid, Feb. 18, 2010). Does winning matter?

As predicted by Heslop, Nadeau and O'Reilly (2010, p. 424), public opinion research found there to be a definite relationship between winning and pride, and it was believed that the successful hosting of the 2010 Olympics created a tremendous sense of pride among residents of the host country.

Half of respondents (49 per cent) expected several Canadian athletes and teams to win gold medals in Vancouver, while 25 per cent believed at least one gold medal would be awarded to Canada (Angus Reid, Nov. 20, 2009). 72 per cent believed that Canada must finish first in the overall medal standings-or in the top five-for the Games to be considered a success (Angus Reid, Feb. 18, 2010). This number increased slightly to 75 per cent a few weeks later (Angus Reid, March 14, 2010). 
During the Olympics, the impact of Canada's 14 gold medals and 26 medals overall appears to have contributed to a growing level of pride that $\mathrm{BC}$ residents felt about hosting the Games. Before the Olympics started, 84 per cent of BC residents expected an excellent or good performance from Canadian athletes. This number grew to 90 per cent at beginning of Olympics; dropped to 76 per cent after the first week of the Games; then went up to 98 per cent after the Games when the final medal count was tallied (Ipsos Reid, March 2, 2010).

\section{A defining national moment?}

One-half of all Canadians ( 52 per cent) believed that the Vancouver Olympic Games were more of a defining national moment than the 1972 Hockey Summit Series, the 1976 Montreal Olympics, the 1988 Calgary Olympics, and Expo 67 (Ipsos Reid, Feb. 23, 2010).

\section{Protests}

As the Olympics progressed, there was a shift in public opinion about protests in Vancouver among residents living in the Vancouver to Whistler corridor.

One week before the Olympics began, 59 per cent of Vancouver residents agreed that the Olympics were a waste of money that could be used for other more important things. One week later, following the violent protests in the city, only 55 per cent on residents agreed, a decrease of four per cent (Angus Reid, Feb. 18, 2010).

When asked about restrictions on protests during the Olympics one week before the Games, 41 per cent of residents agreed that there should be no 
restrictions on protests. This number went down ten per cent the following week when only 31 per cent of residents felt there should be no restrictions, perhaps because of the vandalism and protests that had just occurred (Angus Reid, Feb. 18, 2010).

The number of Vancouver residents who felt protests should be allowed only in certain places and times during the Olympics increased during the Olympics, from 37 per cent before the opening to 45 per cent one week later (Angus Reid, Feb. 18, 2010).

Similarly, the number of residents who said there should be no restrictions on protests during the Olympics increased from 31 per cent before the Games opened to 41 per cent the following week. There was also a slight increase in the proportion of residents who wanted to ban protests altogether during the Olympics, from 12 per cent before the Games to 14 percent one week later (Angus Reid, Feb. 18, 2010). Legacy. Who are the Olympics for?

Four-in-five Canadians said the Games were staged for the benefit of politicians (84 per cent), the elites (82 per cent), and athletes and their families (79 per cent). Fewer Canadians thought the Games were staged for the benefit of sports fans (67 per cent), children (34 per cent) or people like them (26 per cent) (Angus Reid, Feb. 11, 2010).

\section{Good idea or mistake?}

Most Canadians - even BC residents - believed the Olympics were a "great 
idea". British Columbians were hesitant to embrace the Olympics in pre-Olympics surveys, with only 1 in 5 saying it was a "great idea". But in the post-Olympics survey, this support rose sharply to 51 per cent, while the amount believing it was a "mistake" was constant at 39 per cent (Innovative Research Group, Jan. 2010).

\section{Summary}

This public opinion research provided qualitative or quantitative information on how the Canadian population experienced the Olympics, whether there was a shift in feelings of pride experienced during the Olympics, and what effect pride had on individual Canadians, their communities, and the country as a whole. Given that pride is a subjective term, these findings helped to provide a snapshot of what Canadians said and felt about the Olympics and whether there were differences across the country or changes as the Games progressed. The populations studied included and often compared Canadians across the country, British Columbia residents, or people living in the Vancouver or Whistler area.

Based on the findings, it can be concluded that the majority of Canadians whether living across the country or in Vancouver - were supportive of the Games, had a positive experience, watched and enjoyed many of the events, and felt an increased sense of pride. Support for the Olympics grew as the Games progressed, as Canadian athletes won more medals, and as stories and images of the Games were shared through the media and personal experiences. 


\section{Conclusion}

It is now almost a year since the $\mathbf{2 0 1 0}$ Olympic flame was extinguished and the last of the athletes, volunteers and spectators went home. For those Canadian athletes who competed in Vancouver or Whistler, there were many memories of dreams fulfilled, disappointing results, heroic acts, stories of excitement and love, and reminiscences of an event that may never be repeated in their athletic careers. While going to the Olympics was special for athletes around the world, the 2010 Olympics were particularly important for Canadian athletes because they took place on home soil.

For the Canadian public, the Olympics Games were many things, including inspirational, interesting, pride-producing, unifying and a cause for celebration across the country. Looking back on the public expressions of pride, the results of public opinion polls, and endless stories in the media about Canadian athlete hardship and achievement, it can be argued that the 2010 Olympics successfully reached their goal "to touch the soul of the nation and inspire the world by creating and delivering an extraordinary Olympic and Paralympic experience with lasting legacies." (VANOC web site).

The academic literature on the relationship between pride and the Olympics generally agreed that the Olympics had the ability to enhance national pride, and that they were a tool that could be used to create and reproduce a sense of identity, to stimulate national pride and unity, and to positively benefit the host nation. By 
using the 2010 Vancouver Olympics as a case study, these arguments were tested and the conclusions of scholars supported.

IOC President Jacques Rogge talked about the importance of passing on lessons learned and legacies from one Olympic organizing committee to another at the 2010 debrief to the 2012 London and 2014 Sochi Olympic operating committees, held on July 7,2010 . He said this gave future host cities a comprehensive look at what worked well and what could be improved from the previous Olympic Games. The objective was to provide organizers of upcoming Olympic Games with information that they can then adapt and apply to their own edition, if they feel that it will improve their operations or enhance their Games vision.

This year it was Vancouver's turn to pass the torch. The debrief was an opportunity to share VANOC's experience, enabling future operating committees to innovate in their own Games and increase the legacy that they will leave to their communities and the Olympic movement once the Games are over.

"Vancouver hosted excellent Games in February, leaving a great legacy for the city, region, country and Olympic movement. From the feeling of unity Canadians felt from coast to coast - undoubtedly aided by a Winter Olympic record 14 gold medals - to job creation for disadvantaged citizens and social housing, the Games not only carved out a place in Canada's history but also its future. Sharing their observations in a spirit of friendship will help to further perpetuate all the good that came out of 
the 2010 Olympic Winter Games," said Rogge, in a news release posted on the $10 C$ web site (IOC, June 7,2010$)$.

An analysis of the Vancouver Olympic experience found that a number of factors, activities or circumstances were more effective than others in increasing Canadian pride during the Olympics, and these were both planned and/or spontaneous. While specific planned activities, initiatives and approaches helped to increase pride, there were a significant number of unplanned, spontaneous and unpredictable events that also contributed.

VANOC's strategic business and communications plans set out detailed protocols and practices that were used to both proactively create a positive experience and reactively deal with negative situations that arose, such as protests. Staff worked around the clock to control information, stage events and activities, prepare and provide carefully scripted public information, and deal with the media, public and stakeholders as they collectively worked to package the Olympic experience and promote all that is good about the Olympics. In many ways this approach succeeded, and VANOC was instrumental in creating a positive Olympic experience for both residents of Vancouver and people living across Canada.

Similarly, the CTV-Rogers broadcast consortium, as the official Olympic broadcaster, had the dual requirements to respond to the $1 O C^{\prime}$ 's communications needs to spread and promote the principles and values of Olympism, and to provide coverage of the Olympics in a way that would be both objective and responsible, and 
meet their economic need to make money through commercial endeavours. This resulted in thorough and extensive media coverage of the Games, which further promoted pride.

The tools used by VANOC that had the greatest impact on Canadian pride were the strong vision and leadership by CEO John Furlong in making the Olympics "Canada's Games", the cross-Canada torch relay, the red mittens campaign, the cultural events and activities in Vancouver, and the involvement of volunteers. While these were by no means the only activities that contributed, they represented the most successful planned activities and approaches.

Another important ingredient was athlete success since the Vancouver experience found that winning did matter to many Canadians - but not to all - and that national pride was linked to athlete success at the Olympics. The success of the Canadian team was considered to be a critical component to the success of the Games and was viewed as a nation builder.

To help facilitate athlete success, Canada's Own The Podium program was arguably a success, although it was not without its critics at the beginning, and some athletes still felt that it could have been managed differently. The OTP program provided significant resources for athlete development in sports where success was most likely. Although not all sports that were funded won medals, none of the sports that didn't receive finding managed to win any medals. The relationship between financial investment and results was supported by the results of OTP funded sports 
and athletes, and the model of funding appeared to have worked. In fact, the IOC and the 2014 Sochi organizing committee viewed the OTP model as an important component of a successful hosting country plan, and this may create an important legacy for Canada in the future.

The ongoing success of the OTP program and its role in athlete success will be tested in the coming 2012 Summer Olympics in London and 2014 Winter Olympics in Sochi. Although the program continues to provide funding for Canadian athletes, the level of funding decreased somewhat following the Vancouver Games, and annual reviews of athletes and sports made by OTP staff may result in further changes of funding levels and therefore changing expectations of success. Since Canada is widely regarded as a winter sport nation, with more expectations of success at winter Games than at summer events, it is also possible that the upcoming summer Olympics will not result in the kind of success needed to rationalize continued funding of the OTP, and will therefore not prove to be as useful a tool for promoting athlete success and therefore national pride. Can Canadians experience the same sense of pride if the Games are not on home soil, or if Canadian athletes do not perform as well at either the 2012 summer Games in London or the 2014 Games in Sochi?

The concept of the OTP program and its impact on national pride were publicly debated. People agreed that they felt good when Canadian athletes won, and that winning made them feel proud, however there was some question about 
how "Canadian" it was to want to win so badly. While many Canadians appeared to feel comfortable expressing their desire to win and to meet the ambitious goals of the OTP, there were others who regarded the new Canadian directness and confidence with discomfort, and as an unnatural, un-Canadian behaviour.

Ken Dryden, a retired NHL hockey player and Liberal Member of Parliament, recently published a book called Becoming Canada, in which he wrote that Canadians had paid a price for having the wrong sense of ourselves as a country. He suggested that the old definition of Canada - genial but sometimes too self-deprecating and ambition-killing - is no longer the real story. Through recent global events such as Barack Obama's election and first year in office; the climate conference in Copenhagen; and even the 2010 Winter Olympics, Dryden examined the importance of a nation finding its true narrative in order to thrive. He said Canadians need to start telling "a new story" about ourselves, in order to succeed - and fulfill our potential - in this globalized world. In a CBC Radio interview of Dryden on October 12,2010 , he stated "If you do have that typically Canadian "eh" version of yourself in your heads, with only that self-deprecating humour, we end up cutting ourselves at the knees. We are different now. We are better than that now. And we also represent in Canada something that really is a global experiment."

In addition to the planned factors, it was clear that there was a certain amount of luck and magic involved in inspiring Canadians and enhancing pride. Some people referred to the Vancouver Olympics as "the perfect storm", that ideal 
combination of planning and luck and circumstance that resulted in a success few could have imagined. Using the cake analogy, the Vancouver Olympic cake was baked using a number of ingredients that were expected to produce a very good but predictable cake, but a few last minute ingredients were thrown in and the cake turned out better than anyone could have anticipated.

"The magic happened because all the ingredients were there. What came first - the planned activities or the unexpected things that happened? Could we ever envision what happened? I don't think so. We could have imagined all the pieces, but the coming together of these created the perfect storm. I don't think anyone foresaw the perfect storm. You can't predict that," said Tim Gayda. "We had a lot of things going for us at the beginning. The summer Games are not in our DNA the way the winter Games sports are. To have Canadians win a gold medal in the last event of the Vancouver Games, you can't write it any better."

The pride that took hold of Canadians wasn't just about winning medals. It was also the result of stories told in the media about people overcoming the odds, or about extraordinary things happening. Some of the stories that pulled at people's heart strings included Alexandre Bilodeau's winning of the first gold medal and celebrating with his disabled brother; when Joannie Rochette skated to a bronze medal just days after her mother died unexpectedly; when Jon Montgomery won the skeleton event and walked through the Whistler Square drinking from a pitcher of beer; when the Canadian women's hockey team won a gold medal and celebrated on 
center ice with booze and cigars; and of course when countless Canadian athletes graciously and unexpectedly won (or lost) medals and displayed their good Canadian manners.

What difference did the Olympic euphoria really make to Canadians, and will the sense of pride last or just fizzle away? Stephen Brunt said, "people want to go back into the moment because they like the feeling. It's nice to be proud and happy and sentimental and celebrate yourself. The Olympics was an opportunity to do that. The other thing that happened - the Olympics caught this rather than created it was that Canadians have been cocooning in their culture a bit. With borders and lines disappearing or breaking down and the perpetual availability of world culture, the whole idea of identity gets pretty shaky. I don't think you'll get that feeling again from a Games. In the summer, there's not that national pride that the hockey game creates with the best athletes of the world competing for their honour."

"I don't know that we're any more confident, but I think people's hearts beat a little faster when they think about who they are and what they are," said Brunt. "I saw a new Canada on the streets of Vancouver. People had this moment of patriotism and flag-waving, and they're happy in their identify. I don't think that's gone. I think that's lingering out there. But I don't think we're going to go out there and kick the world's ass. That's not what it was about."

Assuming that some of that pride lasts in some way for some people, what did it really achieve? Feeling good about yourself or your country is a wonderful 
thing, but is it worth the expense of hosting an Olympic Games? Gayda argued that there are many ways this pride will make a difference. "Governments are investing in sport because they see it as a mechanism to have healthy citizens and stronger communities. Kids in elementary school are overweight and not exercising. The cost of these kids growing up not exercising or being active is much higher than what it is to get them involved in sport. Governments are thinking sport investment pays off. It's a whole change in investment in active living."

John Furlong said, "the day after the Games, half the children in the country woke up wanting to be Sidney Crosby and Hailey Wickenheiser or that skip on the curling team. We've changed the way people view sport. People are seeing the power that sport has. They're now going to see a time when more and more young people have experienced the pleasure of sport because of this."

Vancouver Sun reporter Stephen Hume argued that sport does matter. "It matters for a host of reasons, not the least of which is that virtually every government on the planet is deeply invested... Governments are invested in sport not out of principle but out of pragmatism. They understand, as did the newly elected Nelson Mandela when he took office in a South Africa teetering at the brink of civil chaos and perhaps even race war, that "politics divide, sport unites"... Governments support global events such as the Olympics because the state perceives sport's unifying value in ameliorating the tensions of tribal, racial, ethnic, religious, regional and class differences." 
On a strictly Canadian level, Dryden said, "the goal of the Olympics is to do well, is to win medals and achieve excellence. If Canada is trying to win contracts around the world, then you had better be out there aiming to win. If you want to excel in Canada and want to be the best, you have to be prepared to actually say you want to be the best. And realize that there's nothing wrong with that."

Measuring the long-term effect of increased pride will be difficult to do and the results may not be available any time soon. The streets of Vancouver are open to regular traffic and only time will tell if there is another opportunity to throw another city-wide street party. The Olympic clothing bought by thousands will continue to be worn out of practicality, and many a shirt and jacket have been spotted at Ottawa gyms and on Ottawa streets this past Fall. The red mittens worn by so many last year continue to be worn, and the Canadian Olympic Foundation, who is betting that Canadians will open their wallets to buy this symbol of Canadian success and devotion, launched a new version of the red Olympic mittens in September 2010. As was demonstrated by the Vancouver 2010 Olympics, hosting an Olympic Games is an experience that can inspire and enhance national pride, and leave a country such as Canada satisfied by a successful event. It appears that the recipe for baking a successful cake of national pride includes equal parts of planned and spontaneous activities with a generous helping of luck, circumstance and medal winning success. 


\section{References}

\section{Primary Sources}

Organizers

Ann Duffy, VANOC Sustainability Spokesperson (Telephone interview: Oct. 13, 2010)

Tim Gayda, President and CEO of Sport BC (Telephone interview: Oct. 15, 2010)

Stephanie Snider, VANOC Communications (Telephone interview: Oct. 18, 2010)

Maureen Douglas, VANOC Communications (Telephone interview: Oct. 19, 2010)

Graeme Menzies, VANOC Social Media Director (Telephone interview: Oct. 19, 2010)

John Furlong, VANOC Chief Executive Officer (Telephone interview: Oct. 20, 2010)

Renee Smith-Valade, VANOC Director of Communications (Telephone interview: Oct. $22,2010)$

Alex Baumann, President, Own The Podium (Telephone interview: Oct. 25, 2010)

Michael Chambers, Past President, Canadian Olympic Committee (Telephone interview: Oct. 27, 2010)

\section{Athletes}

Mellisa Hollingsworth, Olympic athlete - skeleton (Telephone interview: Oct. 21, 2010)

Erik Guay, Olympic athlete - alpine skiing (Telephone interview: Oct. 26, 2010)

\section{Volunteers, residents}

Cheryl de Leeuw, Volunteer at ski jumping (Telephone interview: Oct. 12, 2010)

Christine Brandt, Vancouver resident (Telephone interview: Oct. 19, 2010)

\section{Media}

Marc Dinsdale, CTV Olympic web site content manager (Telephone interview: Oct. 15, 2010)

Jeff Lee, Vancouver Sun reporter (Telephone interview: Oct. 22, 2010)

Stephen Brunt, Globe \& Mail and video essay creator (Telephone interview: Oct. 27, 2010) 
Reports, news releases and web sites

CBC Sport. "CTV wins 2010 and 2012 Olympic broadcast rights, February 9, 2005." News release. February 9, 2005, http://www.cbc.ca/sports/story/2005/02/07/ctv050207.html

Database Olympics. "Medal Count for the 1976 Olympics." http://www.databaseolympics.com/country/countryyear.htm?g=19\&cty=CAN

Database Olympics. "Medal Count for the 1988 Olympics." http://www.databaseolympics.com/country/countryyear.htm?g=41\&cty=CAN

International Olympic Committee. "The Vancouver Debrief in Sochi." News release. June 7, 2010, http://www.olympic.org/en/content/Olympic-Games/All-FutureOlympic-Games/Winter/Sochi-2014-winter-olympics/?articleNewsGroup=1\&articleld $=91229$

International Olympic Committee. "Olympic Charter." 2010, http://www.olympic.org/en/content/The-IOC/

Maclntrye, Jane. "Jane's 2010 Olympic Adventure." Blog, http://janesolympicadventure.blogspot.com/

Own The Podium. "Canadians Want Canada to Own the Podium in 2010 and Beyond: Over 7 out of 10 Canadians want a top 3 result for Canada at the Vancouver 2010 Games and for an initiative like Own the Podium to continue." News release. February 11, 2010, http://www.ownthepodium2010.com/News/default.aspx?n=7

Rogge, Jacques. "The Vancouver Debrief in Sochi." News release. June 7, 2010, http://www.olympic.org/en/content/Olympic-Games/All-Future-OlympicGames/Winter/Sochi-2014-winter-olympics/?articleNewsGroup=1\&articleld $=91229$

The Vancouver Organizing Committee for the 2010 Olympic and Paralympic Winter Games ."Canada: We own the podium, say Canadians." News release. February 28, 2010, http://www.vancouver2010.com/olympic-news/n/news/afpnews/canada--we-own-the-podium--say-canadians 297516Gi.html

The Vancouver Organizing Committee for the 2010 Olympic and Paralympic Winter Games. "Closing Ceremony: Canada says congratulations and goodbye to world's top winter athletes." News release. February 28, 2010, http://www.vancouver2010.com/olympic-news/n/news/the-vancouver-2010olympic-winter-games-by-the-numbers 297848Rg.html 
The Vancouver Organizing Committee for the 2010 Olympic and Paralympic Winter Games. "Governor General of Canada hosts high-energy gathering of youth to empower Canada's young leaders, promote peace as part of Vancouver 2010 Olympic Truce." News release. February 11, 2010, http://www.vancouver2010.com/olympic-news/n/news/governor-general-ofcanada-hosts-high-energy-gathering 273484xi.html

The Vancouver Organizing Committee for the 2010 Olympic and Paralympic Winter Games. "Olympic Games: Games chiefs hit back at criticism." News release. February 16, 2010, http://www.vancouver2010.com/olympicnews/n/news/afp-news/olympic-games--games-chiefs-hit-back-atcriticism 280612tA.html

The Vancouver Organizing Committee for the 2010 Olympic and Paralympic Winter Games. "Olympic Medals: Why bronze shines brighter than silver." News release. February 10, 2010, http://www.vancouver2010.com/olympicnews/n/news/afp-news/olympic-medals--why-bronze-shines-brighter-thansilver 2846100P.html

The Vancouver Organizing Committee for the 2010 Olympic and Paralympic Winter Games. "One month to go: 2010 Winter Games outdoor venue teams matching wits with Mother Nature." News release. January 11, 2010, http://www.vancouver2010.com/olympic-news/n/news/one-month-to-go-2010-winter-games-outdoor-venue-teams-matching-wits-with-mothernature 208636ih.html

The Vancouver Organizing Committee for the 2010 Olympic and Paralympic Winter Games. "Raise a Glass for Team Canada!" News release. February 4, 2010, http://www.vancouver2010.com/olympic-news/n/news/feature-stories/raisea-glass-for-team-canada- 265998cJ.html

The Vancouver Organizing Committee for the 2010 Olympic and Paralympic Winter Games. "The Impact of the Vancouver Games: What the Polling Tells Us." News release. March 1, 2010, http://www.sportmatters.ca/Images/The\%20Impact\%20of\%20the\%20Vancouv er\%20Games\%20SMG\%20Analytical\%20Summary\%20March\%202010\%20v1\%2 Orev\%201.pdf

The Vancouver Organizing Committee for the 2010 Olympic and Paralympic Winter Games. "The Vancouver 2010 Olympic Winter Games: By the numbers." News release. February 28, 2010, http://www.vancouver2010.com/olympicnews/n/news/the-vancouver-2010-olympic-winter-games-by-thenumbers 297556Ko.html 
The Vancouver Organizing Committee for the 2010 Olympic and Paralympic Winter Games. "The Vancouver 2010 Experience." News release. February 7, 2010, http://www.vancouver2010.com/olympic-news/n/news/the-vancouver-2010experience 270186 wy.html

The Vancouver Organizing Committee for the $\mathbf{2 0 1 0}$ Olympic and Paralympic Winter Games. "Vancouver 2010 cancels 'general admission standing room' tickets to snowboard half pipe, ski cross and snowboard parallel giant slalom events at Cypress Mountain Tickets to be refunded." News release. February 16, 2010, http://www.vancouver2010.com/olympic-news/n/news/vancouver-2010cancels-general-admission-standing-room-tickets--to-snowboard-halfpipe--skicross-and--snowboard-parallel-giant-slalom-events-at-cypress-mountain-tickets-to-be-refunded-- $280034 \mathrm{dW}$.html

The Vancouver Organizing Committee for the 2010 Olympic and Paralympic Winter Games. "Vancouver 2010 Sustainability Report, 2008-2009." http://www.vancouver2010.com/more-2010information/sustainability/reports-and-resources/sustainability-report/

The Vancouver Organizing Committee for the 2010 Olympic and Paralympic Winter Games. "Vancouver 2010 Bid Book, 2002." http://www.vancouver2010.com/more-2010-information/aboutvanoc/organizing-committee/bid-history/bid-book/bid-book 88094qM.html

The Vancouver Organizing Committee for the 2010 Olympic and Paralympic Winter Games. "VANOC thanks Canadians, fans, for wearing hearts on their hands." News release. March 5, 2010, http://www.vancouver2010.com/olympicnews/n/news/red-mittens 303978yw.html

The Vancouver Organizing Committee for the 2010 Olympic and Paralympic Winter Games. "VANOC confirms team effort paying off to ready Cypress Mountain for 2010 Olympic Winter Games." News release. January 28, 2010, http://www.vancouver2010.com/olympic-news/n/news/vanoc-confirms-teameffort-paying-off-to-ready-cypress-mountain-for-2010-olympic-wintergames 237068EP.html

The Vancouver Organizing Committee for the $\mathbf{2 0 1 0}$ Olympic and Paralympic Winter Games. "VANOC board of directors declare Vancouver and Whistler ready to host the world in 23 days." News release. January 20, 2010, http://www.vancouver2010.com/olympic-news/n/news/vanoc-board-ofdirectors-declare-vancouver-and-whistler-ready-to-host-the-world-in-23days 234938tn.html

The Vancouver Organizing Committee for the 2010 Olympic and Paralympic Winter Games. "Victory Ceremony podiums at 2010 Winter Games a testament to the 
mountains athletes have climbed en route to Olympic and Paralympic success." News release, http://www.vancouver2010.com/olympic-news/n/news/victoryceremony-podiums-at-2010-winter-games-a-testament--to-the-mountainsathletes-have-climbed-en-route-to-olympic-and-paralympicsuccess 264996fr.html

\section{Secondary Sources}

Journal articles and books

Bale, J. "Sport and national identity: A geographical view." British Journal of Sports History (1986): 3, 18-41.

Bairner, Alan. "Sportive Nationalism and Nationalist Politics: A Comparative Analysis of Scotland, the Republic of Ireland, and Sweden." Journal of Sport \& Social Issues (August 1996): 20 (3), pg. 314-334.

Billings, Andrew, and James Angelini. "An Agenda That Sets the Frames: Gender, Language, and NBC's Americanized Olympic Telecast." Journal of Language and Social Psychology (September 2010): 29 (3), pg. 363-385

Billings, A. C., and J. J. Angelini. "Packaging the games for viewer consumption: Gender, ethnicity, and nationality in NBC's coverage of the 2004 Summer Olympics." Communication Quarterly 55, no. 1:95-111.

Billings, A. C., and S. T. Eastman. "Framing identities, gender, ethnic, and national parity in network announcing of the 2002 Winter Olympics." Journal of Communication 53 (2003): no. 4:569-586.

Bockrath, Franz, and Elk Franke. "Is there any Value in Sport? About the Ethicial Significance of Sport Activities." International Review for the Sociology of Sport. (January 1995): 30 (3-4), pg. 283-309.

Bradbury, Danny. "An Olympic effort to secure the Games." Infosecurity (January 2010): 7 (1), pg. 22-26

Cho, Younghan. "Unfolding sporting nationalism in South Korean media representations of the 1968, 1984 and 2000 Olympics." Media, Culture \& Society (2009): Vol. 31(3): pg. 347-364

De Bosscher, V., De Knop, P., van Bottenburg, M., \& Shibli, S. “Explaining international sporting success: An international comparison of elite sport systems and policies in six countries." Sport Management Review (August 2009): 12 (3), pg. 113-136 
De Knop, Paul, Maarten van Bottenburg, Simon Shibli, and Jerry Bingham. "Explaining international sporting success: An international comparison of elite sport systems and policies in six countries." Sport Management Review (August 2009): 12 (3), pg. 113-136

Evans, M.D.R., and Jonathan Kelley. "National Pride in the Developed World: Survey Data from 24 nations." International Journal of Public Opinion Research (2002): Vol. 14. No. 3, pg. 303-338.

Gems, Gerald, "Puerto Rico: Sport and the Restoration of National Pride." International Journal of Regional and Local Studies (Spr 2005): ser2 v1 no1

Hargreaves, J. "Olympism and nationalism: Some preliminary considerations." International Review for the Sociology of Sport (1992): 27, 119-137.

Heslop, Louise, John Nadeau, and Norm O'Reilly. "China and the Olympics: views of insiders and outsiders." International Marketing Review (January 2010): 27 (4), pg. 404-433

Horak, Roman, and Georg Spitaler. "Sport Space and National Identity: Soccer and Skiing as Formative Forces: On the Austrian Example." The American Behavioral Scientist (2003): 46, no. 11:1506-1518.

Housel, Teresa H. "Australian Nationalism and Globalization: Narratives of the Nation in the 2000 Sydney Olympics' Opening Ceremony." Critical Studies in Media Communication (2007): 24, no. 5:446-461.

Hunter, John S. "Flying the Flag: Identities, the Nation, and Sport." Identities (2003): 10 , no. 4:409-425.

Hutchins, Brett, and Janine Mikosza. "The Web 2.0 Olympics: Athlete Blogging, Social Networking and Policy Contradictions at the 2008 Beijing Games." Convergence (August 2010): 16 (3), pg. 279-297.

Jackson, S. J. "Exorcizing the ghost: Donovan Bailey, Ben Johnson and the politics of Canadian identity." Media, Culture \& Society (2004): 26, no. 1:121-141.

Jarvie, Grant. "Internationalism and Sport in the Making of Nations." Identities (2003): 10, no. 4:537-551.

Karkatsoulis, Panos, Nikos Michalopoulos, and Vasso Moustakatou. "The national identity as a motivational factor for better performance in the public sector." International Journal of Productivity and Performance Management (January 2005): 54 (7), pg. 579-594.

Kellas, J.G. "The politics of nationalism and ethnicity." Basingstoke, England: Macmillan. 1991. 
Kemp, Sharon. "The hidden workforce: volunteers learning in the Olympics." Journal of European Industrial Training (January 2002): 26 (2/3/4), pg. 109-116

Knight, Graham, Margaret MacNeill, and Peter Donnelly. "The Disappointment Games: Narratives of Olympic Failure in Canada and New Zealand." International Review for the Sociology of Sport (March 2005): 40 (1), pg. 25-51.

Kymlicka, Will. "Being Canadian". Government and Opposition (2003): 38, no. 3:357385.

Labuschagne, Pieter. "The Impact of Sport on Nation Building: A Critical Analysis of South Africa and the 2010 FIFA World Cup." Africa Insight (2008): 38, no. 3:3114.

Lechner FJ. "Redefining national identity: Dutch evidence on global patterns." International Journal of Comparative Sociology (2007a): 48(4): 355-68.

Marshall, P. David, Becky Walker, and Nicholas Russo. "Mediating the Olympics." Convergence: The International Journal of Research into New Media Technologies (2010): Vol 16(3): 263-278.

McCallum, Katherine, Amy Spencer, and Elvin K. Wyly. "The City as an Image-creation Machine: A Critical Analysis of Vancouver's Olympic Bid." Yearbook of the Association of Pacific Coast Geographers (August 2005), 67 (1), pg. 24-46.

Morris, Jason. "Skating on Thin Ice: Hockey and the Canadian National Identity." Proteus (2008): 25, no. 2:47-268.

Neilson, B. "Bodies of protest: performing citizenship at the 2000 Olympic games." Continuum: Journal of Media \& Cultural Studies (2002): 16, no. 1:13-25.

Qiongli, W. "Commercialization of digital storytelling: An integrated approach for cultural tourism, the Beijing Olympics and wireless VAS." International Journal of Cultural Studies (2006): 9, no. 3:383-394.

Rothenbuler, E. W. "The living room celebration of the Olympic games." Journal of Communication (1988): 38, no. 4:61-81.

Seppanen, Paavo. "The Olympics: A Sociological Perspective." International Review for the Sociology of Sport (January 1984): 19 (2), pg. 113-127.

Shipway, Richard. "Sustainable legacies for the 2012 Olympic Games." The Journal of The Royal Society for the Promotion of Health (May 2007): 127 (3), pg. 119-124.

Scherer, Jay, and David Whitson. "Public Broadcasting, Sport, and Cultural Citizenship: The Future of Sport on the Canadian Broadcasting Corporation?" International Review for the Sociology of Sport (June 2009): 44 (2-3), pg. 213229. 
Tracy, Jessica, Azim Shariff, and Joey Cheng. "A Naturalist's View of Pride." Emotion Review (April 2010): 2 (2), pg. 163-177.

Van Hilvoorde, Ivo, Agnes Elling, and Ruud Stokvis. "How to influence national pride? The Olympic medal index as a unifying narrative." International Review for the Sociology of Sport (March 2010): 45 (1), pg. 87-102.

Vitaliev, Dmitri. "Canada aims for green games". Engineering\&Technology (February 2010): 5 (2), pg. 23-25.

Walseth, Kristin. "Sport and Belonging." International Review for the Sociology of Sport (September 2006): 41 (3-4), pg. 447-464.

WaltGron H, Longo A, Dawson D. "A Contingent Valuation of the 2012 Lindon Olympic Games: A Regional Perspective." Journal of Sports Economics (June 2008): 9 (3), pg. 304-317.

Zaharopoulos, T. "The news framing of the 2004 Olympic Games." Mass Communication \& Society (2007): 10, no. 2:235-249.

\section{Public Opinion Research}

Angus Reid Public Opinion. "2010 Winter Olympics: Canadians Interested in Vancouver Winter Olympics; Less Keen on Torch Relay." Nov. 20, 2009.

Angus Reid Public Opinion. "Vancouver 2010 Winter Olympics: Most Americans Will Follow Vancouver 2010 Winter Olympics." Jan. 21, 2010.

Angus Reid Public Opinion. "Vancouver's Reputation: As Winter Olympics Approach, Britons and Americans Are Fond of Vancouver." Feb. 3, 2010.

Angus Reid Public Opinion. "Vancouver 2010 Winter Olympics: Vancouverites Foresee Positive Legacy and a Considerable Deficit from Olympic." Feb. 11, 2010.

Angus Reid Public Opinion. "Vancouver 2010 Winter Olympics: Vancouverites Ambivalent About Winter Olympic Games." Feb. 11, 2010.

Angus Reid Public Opinion. "Vancouver 2010 Winter Olympic Games: Ambivalence Gives Way to Olympic Enthusiasm in Metro Vancouver." Feb. 18, 2010.

Angus Reid Public Opinion. "Vancouver 2010 Winter Olympics: Canadians Provide High Marks to Vancouver 2010 Opening Ceremony." Feb. 18, 2010.

Angus Reid Public Opinion. "Success in Sports: Americans and Canadians Differ on What Constitutes Olympic Success." March 14, 2010.

Canadian Press/Harris Decima. "Canadians See Benefit to Hosting Games, B.C. Residents Remain Skeptical." Jan. 27, 2010. 
Canadian Press Harris/Decima survey. "Canadians See Silver Linings More than Clouds at Vancouver Olympics." Feb. 22, 2010.

Canadian Press/Harris Decima Research. "Canadians Close the Olympics Satisfied." March 1, 2010.

Decima Research. "Canadians' Awareness of the 2010 Olympic and Paralympic Winter Games." Feb. 22, 2010.

Decima Research. "Canadians' Awareness of the 2010 Olympic and Paralympic Winter Games." March. 2010.

Decima Research. "Canadians' Awareness of the 2010 Olympic and Paralympic Winter Games." May 25, 2010.

Decima Research. "Canadians'Awareness of the 2010 Olympic and Paralympic Winter Games." July 12, 2007.

Ekos Reseach Associates Inc. "2009 Status of the High Performance Athlete: Final Report." March 31, 2010.

Innovative Research Group. "Canadians on the Olympics." January 2010.

Innovative Research Group. "Canadians on the Olympics." March 2010.

Ipsos Reid. "Local Pressure for Olympic Podium Mount.", Feb. 11,2010.

Ipsos Reid. "British Columbians give Opening Ceremony a Gold Medal." Feb. 16, 2010.

Ipsos Reid. "Canada at the Games: History in the Making." Feb. 23, 2010.

Ipsos Reid. "Ratings for the 2010 Olympic Winter Games Peak as Canada wins Gold." March 2, 2010.

Ipsos Reid. "Eight in Ten (80\%) Call Themselves a "Canadian Nationalist". Up 8 points from one year ago." March 8, 2010.

Nanos Report. "Canadians Embrace Olympic peace." Feb. 11, 2010.

Robbins SCE Research, Zeus Poll. "Vancouver-Whistler 2010 Winter Olympic Games." July 20, 2009.

\section{Newspaper articles:}

Anderson, Fiona. "Downtown eateries booming amid Olympic fever; Crowds are great news for pizza places making extra dough and pubs enjoying weekend parties every day. " The Vancouver Sun 17 Feb. 2010,Canadian Newsstand Complete, ProQuest. Web. 21 Nov. 2010. 
Anderson, Fiona. "Olympics clip float plane firms' profits. " The Vancouver Sun 18 Feb. 2010,Canadian Newsstand Complete, ProQuest. Web. 21 Nov. 2010.

Barnes, Dan. "Chinese pair could break Russia's hold on gold; 'Inspiring' husband-wife duo lead field going into Monday's long program. " The Vancouver Sun 5 Feb. 2010,Canadian Newsstand Complete, ProQuest. Web. 21 Nov. 2010.

Barnes, Dan. "In Canada, women own the podium; Canadian men are out-medalled for the second consecutive Winter Olympics. " The Vancouver Sun 26 Feb. 2010,Canadian Newsstand Complete, ProQuest. Web. 21 Nov. 2010.

Barnes, Dan. "May the fourth be with you -- athletes lament falling short of podium. " The Vancouver Sun 20 Feb. 2010,Canadian Newsstand Complete, ProQuest. Web. 21 Nov. 2010.

Barnes, Dan. "Simply skating is a victory; Despite her mother's recent death, Joannie Rochette performs well -- but she may still choose not to compete. "The Vancouver Sun 23 Feb. 2010,Canadian Newsstand Complete, ProQuest. Web. 21 Nov. 2010.

Barton, Adriana. "For Vancouver, it's time to cash in on Olympic gold." The Vancouver Sun 1 March 2010,Canadian Newsstand Complete, ProQuest. Web. 11 Jan. 2011.

Beamish, Mike. "Canada makes statement on skinny skis; Steady progress into medal contention continues with fourth-place finish in team sprint. "The Vancouver Sun 23 Feb. 2010,Canadian Newsstand Complete, ProQuest. Web. 21 Nov. 2010.

Beamish, Mike. "Exceeding expectations. " The Vancouver Sun 24 Feb. 2010,Canadian Newsstand Complete, ProQuest. Web. 21 Nov. 2010.

Beamish, Mike. "McKeever may be a victim of team's success. " The Vancouver Sun 27 Feb. 2010,Canadian Newsstand Complete, ProQuest. Web. 21 Nov. 2010.

Beamish, Mike. "Medals. " The Vancouver Sun 15 Feb. 2010,Canadian Newsstand Complete, ProQuest. Web. 21 Nov. 2010.

Beamish, Mike. "Newbies. "The Vancouver Sun 25 Feb. 2010,Canadian Newsstand Complete, ProQuest. Web. 21 Nov. 2010.

Beamish, Mike. "Skier Babikov laments fifth-place finish; Coming close just not good enough, athlete says. " The Vancouver Sun 22 Feb. 2010,Canadian Newsstand Complete, ProQuest. Web. 21 Nov. 2010.

Beamish, Mike. "Storybook finish hurts; Slovenia's skiing heroine fights through the pain for bronze, but her Olympics are over. "The Vancouver Sun 19 Feb. 2010,Canadian Newsstand Complete, ProQuest. Web. 21 Nov. 2010. 
Belet, Gery. "Early critics among world media change their tune; 'Boos' turn to 'oohs' as Vancouver gets gold for Games. "The Vancouver Sun 1 March 2010,Canadian Newsstand Complete, ProQuest. Web. 11 Jan. 2011.

Bell, Terry. "Olympic luger dead after high-speed track crash; Track is 'really very bad,' Georgian coach says. " The Vancouver Sun 13 Feb. 2010,Canadian Newsstand Complete, ProQuest. Web. 11 Jan. 2011.

Bell, Terry. "Aussie takes gold after accusations; Jumpers claimed judges favoured China. "The Vancouver Sun 25 Feb. 2010,Canadian Newsstand Complete, Proquest. Web. 21 Nov. 2010.

Bell, Terry. "Shamanism. " The Vancouver Sun 18 Feb. 2010,Canadian Newsstand Complete, ProQuest. Web. 21 Nov. 2010.

Bidini, Dave. "Good times obscure Games' final legacy; Olympics big problems hard to address. " National Post 22 Feb. 2010,Canadian Newsstand Complete, ProQuest. Web. 21 Nov. 2010.

Birnie, Peter. "Grab this page, then go grab a show; The Vancouver 2010 Cultural Olympiad has been in full force for a couple of weeks, and will continue right through the Olympics and Paralympics. Here's a handy guide to help you find your way to the unmissable events underway in theatre, dance, music and the visual and literary arts. " The Vancouver Sun 12 Feb. 2010,Canadian Newsstand Complete, ProQuest. Web. 21 Nov. 2010.

Botchford, Jason. "Luge death raises questions, concerns about 'challengin' sliding course. " The Vancouver Sun 13 Feb. 2010,Canadian Newsstand Complete, ProQuest. Web. 11 Jan. 2011.

Botchford, Jason. "Underdogs. " The Vancouver Sun 26 Feb. 2010,Canadian Newsstand Complete, ProQuest. Web. 21 Nov. 2010.

Bramham, Daphne. "Carver's memory will live in his work; Lil'wat community, suffering a tough winter but proud of its Olympic connection, mourns an artist. "The Vancouver Sun 12 Feb. 2010,Canadian Newsstand Complete, ProQuest. Web. 21 Nov. 2010.

Brennae, Mark. "Canadian fans cheer Colbert, despite the moose jokes; Week-long series of the U.S. comedian's hit show airs from Canada -- or, as he calls it, 'Europe with toilets'. " The Vancouver Sun 23 Feb. 2010,Canadian Newsstand Complete, ProQuest. Web. 21 Nov. 2010.

Cameron, Allen. "Coach kicks Chinese team into high gear for big win; Women cap tumultuous week of curling competition with emotional 12-6 win over Switzerland. "The Vancouver Sun 27 Feb. 2010,Canadian Newsstand Complete, ProQuest. Web. 21 Nov. 2010. 
Cameron, Allen. "European champs. " The Vancouver Sun 18 Feb. 2010,Canadian Newsstand Complete, ProQuest. Web. 21 Nov. 2010.

Cameron, Allen. "Final: Swedes would love to play spoiler; Swedish skip has been hard on Canadians. " The Vancouver Sun 26 Feb. 2010,Canadian Newsstand Complete, ProQuest. Web. 21 Nov. 2010.

Cameron, Allen. "Norway skip knows it's his time to shine; 'The ultimate' after years as understudy. " The Vancouver Sun 26 Feb. 2010,Canadian Newsstand Complete, ProQuest. Web. 21 Nov. 2010.

Cameron, Allen. "Underdog Bernard thrilled to have shot at gold medal today; Anette Norberg of Sweden has more big-game experience, but Canadian curlers are looking forward to the battle on ice. "The Vancouver Sun 26 Feb. 2010,Canadian Newsstand Complete, ProQuest. Web. 21 Nov. 2010.

Cayo, Don. "How safe is safe enough for the Olympics?; Rigorous, transparent mechanisms needed to weigh costs and benefits of security measures. "The Vancouver Sun 22 Feb. 2010,Canadian Newsstand Complete, ProQuest. Web. 21 Nov. 2010.

Celebrating Saskatchewan. Leader Post 24 Feb. 2010,Canadian Newsstand Complete, ProQuest. Web. 21 Nov. 2010.

Cernetig, Miro. "'I've got an idea': The moment our Olympics dream began. "The Vancouver Sun 12 Feb. 2010,Canadian Newsstand Complete, ProQuest. Web. 21 Nov. 2010.

Cernetig, Miro. "Why the Olympic torch ignites and inspires Canadians. "The Vancouver Sun 13 Feb. 2010,Canadian Newsstand Complete, ProQuest. Web. 11 Jan. 2011.

Cernetig, Miro. "Canada's hockey heroes hit Vancouver hot spot. " The Vancouver Sun 18 Feb. 2010,Canadian Newsstand Complete, ProQuest. Web. 21 Nov. 2010.

Cernetig, Miro. "Feeling the heat at street level makes a nice memory. " The Vancouver Sun 24 Feb. 2010,Canadian Newsstand Complete, ProQuest. Web. 21 Nov. 2010.

Cernetig, Miro. "Legally blind skier embodies the Olympic ideal; Brian McKeever will be the first disabled athlete to compete in Winter Games and Paralympics. "The Vancouver Sun 17 Feb. 2010,Canadian Newsstand Complete, ProQuest. Web. 21 Nov. 2010. 
Cole, Cam. "Don't bet the mortgage on 'Own the Podium'; Grandiose expectations for home Olympic Games might need to be scaled down just a little." The Vancouver Sun 20 Feb. 2010,Canadian Newsstand Complete, ProQuest. Web. 11 Jan. 2010.

Cole, Cam; With files from Vicki Hall. "Bilodeau smashes the big jinx; Canada's hometeam curse -- if there ever was one -- is part of sports history now. " The Vancouver Sun 15 Feb. 2010,Canadian Newsstand Complete, ProQuest. Web. 21 Nov. 2010.

Cole, Cam; With files from Vicki Hall, and Canwest. "Bilodeau smashes the big jinx; Canada's 44-year home-team curse -- if there ever was one -- is part of sports history now. "The Vancouver Sun 15 Feb. 2010,Canadian Newsstand Complete, ProQuest. Web. 21 Nov. 2010.

Cole, Cam. "Bettman says not yet, not nyet, for decision on Russia's Olympics; NHL commissioner says it makes good business sense for NHL to fit Vancouver into schedule, but he's not sure about the logistics of 2014. " The Vancouver Sun 19 Feb. 2010,Canadian Newsstand Complete, ProQuest. Web. 21 Nov. 2010.

Cole, Cam. "Canada breaks a 50-year-old Russian curse; But the team still has their eyes on the ultimate prize -- a gold-medal win on home ice. "The Vancouver Sun 25 Feb. 2010,Canadian Newsstand Complete, ProQuest. Web. 21 Nov. 2010.

Cole, Cam. "Vanoc needs to step up to the podium and say sorry. "The Vancouver Sun 17 Feb. 2010,Canadian Newsstand Complete, ProQuest. Web. 21 Nov. 2010.

Cole, Cam. "With heavy hearts, the show had to go on. " The Vancouver Sun 13 Feb. 2010,Canadian Newsstand Complete, ProQuest. Web. 21 Nov. 2010.

Cole, Cam. "Record Olympic gold-medal haul is frosting on the cake; No one could have predicted Canada's fantastic second week, but Own the Podium program shows its value in 72 top-eight finishes." The Vancouver Sun 1 March 2010,Canadian Newsstand Complete, ProQuest. Web. 11 Jan. 2010.

Colem Cam. "Virtue, Moir take ice dancing to new level; 'This is the performance we dreamed of, everything we've ever wanted'. " The Vancouver Sun 23 Feb. 2010,Canadian Newsstand Complete, ProQuest. Web. 21 Nov. 2010.

Collins, Scott. "NBC wins gold in ratings competition; Games coverage topples American Idol from its perch, but overall viewership still lower than most other Winter Olympics. " The Vancouver Sun 23 Feb. 2010,Canadian Newsstand Complete, ProQuest. Web. 21 Nov. 2010. 
Constantineau, Bruce. "If we can stage the Games, we can handle your convention, blog tells world; Tourism Vancouver uploading daily videos aimed at meeting planners. " The Vancouver Sun 13 Feb. 2010,Canadian Newsstand Complete, ProQuest. Web. 21 Nov. 2010.

Constantineau, Bruce. "Olympics an eye-opener for Nova Scotia executive. " The Vancouver Sun 20 Feb. 2010,Canadian Newsstand Complete, ProQuest. Web. 21 Nov. 2010.

Constantineau, Bruce. "Only time will tell if the Games pay off; International businesses brought their best game to the Olympics to stimulate sales. "The Vancouver Sun 27 Feb. 2010,Canadian Newsstand Complete, ProQuest. Web. 21 Nov. 2010.

Constantineau, Bruce. "Phelps enjoys sidelines; It's 'cool to be a spectator,' U.S. swimming star says. " The Vancouver Sun 19 Feb. 2010,Canadian Newsstand Complete, ProQuest. Web. 21 Nov. 2010.

Crawford, Tiffany. "Majority of Canadians happy with Games: poll. "The Vancouver Sun 27 Feb. 2010,Canadian Newsstand Complete, ProQuest. Web. 21 Nov. 2010.

Culbert, Lori. "Crowds not hampered by BC Place security. "The Vancouver Sun 13 Feb. 2010,Canadian Newsstand Complete, ProQuest. Web. 11 Jan. 2011.

Culbert, Lori. "Dad burst into tears as Mclvor won gold; A flood of memories from a lifetime of love and struggle open a loving father's 'flood gates'. " The Vancouver Sun 25 Feb. 2010,Canadian Newsstand Complete, ProQuest. Web. 11 Jan. 2011.

Culbert, Lori; and With a file from George Johnson. "Families along for Games highs and lows; Vocal cheering sections and moral support help athletes deal with tough competition. " The Vancouver Sun 22 Feb. 2010,Canadian Newsstand Complete, ProQuest. Web. 21 Nov. 2010.

Culbert, Lori. "Fans proud of athletes who 'play like girls'; Canada's women have dominated the medal count and many hope this will encourage more girls to get involved in sports. " The Vancouver Sun 26 Feb. 2010,Canadian Newsstand Complete, ProQuest. Web. 21 Nov. 2010.

Culbert, Lori. "Olympic trip gives joy to 5 orphans; Parents killed by drunk driver in Red Deer on Feb. 7. " Edmonton Journal 27 Feb. 2010,Canadian Newsstand Complete, ProQuest. Web. 21 Nov. 2010.

Culbert, Lori. "Weather threat plagues Whistler; Rain, fog pose problems for Vanoc and may mean some events have to be rescheduled. "The Vancouver Sun 12 Feb. 2010,Canadian Newsstand Complete, ProQuest. Web. 21 Nov. 2010. 
Culbert, Lori. "COC celebrates record number of gold medals, defends program. " The Vancouver Sun 1 March 2010,Canadian Newsstand Complete, ProQuest. Web. 11 Jan. 2011.

Daum, Meghan. "The real women of the Winter Games; News flash. " The Vancouver Sun 23 Feb. 2010,Canadian Newsstand Complete, ProQuest. Web. 21 Nov. 2010.

Davis, Craig. "Skating past the tears; Jennifer Rodriguez uses the rink as therapy after her divorce and the death of her mother. "The Vancouver Sun 16 Feb. 2010,Canadian Newsstand Complete, ProQuest. Web. 21 Nov. 2010.

Davis, Kim. "World events that change the game; Olympics have aspired to lead the way in environmental sustainability since 2000. " The Vancouver Sun 27 Feb. 2010,Canadian Newsstand Complete, ProQuest. Web. 21 Nov. 2010.

Donnellon, Sam. "Bet you'll watch some of the Olympics this year; People and stories of the Games -- winter or summer -- are what keep the event interesting. " The Vancouver Sun 15 Feb. 2010,Canadian Newsstand Complete, ProQuest. Web. 21 Nov. 2010.

Dheensaw, Cleve. "If it goes right for hockey, it goes right for Games." The Vancouver Sun 25 Feb. 2010,Canadian Newsstand Complete, ProQuest. Web. 11 Jan. 2011.

Edwards, Alyn. "Historic car out in the cold for the Olympics; The McLaughlin Buick first used in the Royal Tour in 1939 will not be used in the opening ceremonies despite an earlier request. "The Vancouver Sun 12 Feb. 2010,Canadian Newsstand Complete, ProQuest. Web. 21 Nov. 2010.

Eustace, Chantal. "Johnny Weir is ready for his close-up; Coming in sixth doesn't seem to bother the flamboyant U.S. figure skater. " The Vancouver Sun 20 Feb. 2010, Canadian Newsstand Complete, ProQuest. Web. 21 Nov. 2010.

Ewen, Steve. "Canada can't get away from U.S.; Anticipation growing ahead of final. " The Vancouver Sun 24 Feb. 2010,Canadian Newsstand Complete, ProQuest. Web. 21 Nov. 2010.

Ewen, Steve. "Finland vs. Sweden. "The Vancouver Sun 13 Feb. 2010,Canadian Newsstand Complete, ProQuest. Web. 21 Nov. 2010.

Ewen, Steve. "Goalie saves thoughts for cancer fighter; Szabados thrilled to get a start, a victory for unbeaten Canada and an Olympic memory for her inspirational friend. " The Vancouver Sun 16 Feb. 2010,Canadian Newsstand Complete, ProQuest. Web. 21 Nov. 2010. 
Ewen, Steve. "U.S.-Canada rivalry is confused by Thatcher; American and former B.C. Breakers player picks up stick for U.S. team. " The Vancouver Sun 12 Feb. 2010,Canadian Newsstand Complete, ProQuest. Web. 21 Nov. 2010.

Ewen, Steve. "Women's hockey. " The Vancouver Sun 13 Feb. 2010,Canadian Newsstand Complete, ProQuest. Web. 21 Nov. 2010.

Fayerman, Pamela. "Athletes taking a bite out of dentists' workdays; IOC mandates oral care, including cancer screening, for 20 per cent of all competitors. "The Vancouver Sun 15 Feb. 2010,Canadian Newsstand Complete, ProQuest. Web. 21 Nov. 2010.

Fayerman, Pamela. "Local hospitals see surge in emergency department visits; Olympic revellers, mostly drunk male patients aged 15 to 24, treated for intoxication, injuries from fights or falls. " The Vancouver Sun 24 Feb. 2010,Canadian Newsstand Complete, ProQuest. Web. 21 Nov. 2010.

Fowlie, Jonathan; and Culbert, Lori. "The hustle is on for hottest tickets in town; Purchase limits and capacity crowds at the Olympics mean resellers are scrambling for product. " The Vancouver Sun 19 Feb. 2010,Canadian Newsstand Complete, ProQuest. Web. 21 Nov. 2010.

Fralic, Shelley. "Aquavit yes, pickled herring no; Head to Burnaby for the best-kept Olympic secret, Scandanavia House, complete with fireside beers and a laid-back vibe. "The Vancouver Sun 22 Feb. 2010,Canadian Newsstand Complete, ProQuest. Web. 21 Nov. 2010.

Fralic, Shelley. "The Olympic red carpet; Quick, call the fashion police -- some of these outfits are out of control. "The Vancouver Sun 23 Feb. 2010,Canadian Newsstand Complete, ProQuest. Web. 21 Nov. 2010.

Fralic, Shelley. "The other king of the snowboard; Jake Burton, the sport's 'inventor,' talks about superstar Shaun White, the Vancouver Olympics and aging somewhat gracefully. "The Vancouver Sun 19 Feb. 2010,Canadian Newsstand Complete, ProQuest. Web. 21 Nov. 2010.

Gallagher, Tony. "Czech crew prevents huge upset; But Jagr injured in OT victory against Latvia. "The Vancouver Sun 24 Feb. 2010,Canadian Newsstand Complete, ProQuest. Web. 21 Nov. 2010.

Glendinning, Sandra. "Distinct lack of road rage is impressive; Considering the throngs that clog our streets, we've been mostly well behaved. " The Vancouver Sun 26 Feb. 2010,Canadian Newsstand Complete, ProQuest. Web. 21 Nov. 2010. 
Gram, Karen. "Cosy up to Vancouver's coolest bar; For that wintry feeling, sip a vodka martini from a glass made of ice. "The Vancouver Sun 19 Feb. 2010,Canadian Newsstand Complete, ProQuest. Web. 21 Nov. 2010.

Gregorian, Vahe. "Vancouver Games bring Ohno's career full-oval; American's Olympic dream got on track in B.C. " The Vancouver Sun 12 Feb. 2010,Canadian Newsstand Complete, ProQuest. Web. 21 Nov. 2010.

Griffin, Kevin. "Digital edition impresses 2012 planners; Cultural Olympiad in the United Kingdom already underway. " The Vancouver Sun 23 Feb. 2010,Canadian Newsstand Complete, ProQuest. Web. 21 Nov. 2010.

Griffin, Kevin. "Surprises hide in unlikely spots in the Downtown Eastside's public art program; Installations are sprinkled throughout neighbourhood, down hallways and behind windows. " The Vancouver Sun 19 Feb. 2010,Canadian Newsstand Complete, ProQuest. Web. 21 Nov. 2010.

Habdank, Joanna. "Winter at the beach can be just as adventurous as summer; Escape the fast-paced life of the city and the chaotic aftermath of the Olympics with a relaxing getaway to Tofino. " The Vancouver Sun 27 Feb. 2010,Canadian Newsstand Complete, ProQuest. Web. 21 Nov. 2010.

Hall, Neal. "Beer and bratwurst satisfy fans at German party house. "The Vancouver Sun 12 Feb. 2010,Canadian Newsstand Complete, ProQuest. Web. 21 Nov. 2010.

Hall, Neal. "Mounties hoof it into Surrey with popular RCMP musical ride; The star attraction at Surrey's Olympics celebration site, the event has been a Canadian tradition since 1887. "The Vancouver Sun 20 Feb. 2010,Canadian Newsstand Complete, ProQuest. Web. 21 Nov. 2010.

Hall, Vicki. "Canada owns the podium in women's race; Humphries and Moyse claim the gold, while teammates Upperton and Brown take the silver. " The Vancouver Sun 25 Feb. 2010,Canadian Newsstand Complete, ProQuest. Web. 11 Jan. 2010.

Hall, Vicki. "'I was ready. It was just one mistake'; A favourite to win the gold medal, Canada's Mellisa Hollingsworth ricochets off the wall twice to fall from second to fifth. " The Vancouver Sun 20 Feb. 2010,Canadian Newsstand Complete, ProQuest. Web. 21 Nov. 2010.

Hansen, Darah. "Glitches don't dampen super-fan experience; Not even hypothermia can stop a hardcore Olympics booster from cheering on athletes in her home city. " The Vancouver Sun 20 Feb. 2010,Canadian Newsstand Complete, ProQuest. Web. 21 Nov. 2010. 
Haris, Misty. "Bloggers and tweeters take the 2010 Games global; Experts predict IOC social-media restrictions won't work as spectators become more engaged in the Olympics. "The Vancouver Sun 12 Feb. 2010,Canadian Newsstand Complete, ProQuest. Web. 21 Nov. 2010.

Hayes, Marcus. "Will the clothes make the ice dancers?; World-champion Russians, who offended Australian Aborigines, won't say what they're wearing until Sunday's performance. " The Vancouver Sun 19 Feb. 2010,Canadian Newsstand Complete, ProQuest. Web. 21 Nov. 2010.

Herman, Martyn. "No fear. " The Vancouver Sun 19 Feb. 2010,Canadian Newsstand Complete, ProQuest. Web. 21 Nov. 2010.

Hersh, Philip. "Orser has as many fans as his 'golden student'; Former Canadian star skater says all the glory belongs to Yu-Na Kim, but Dorothy Hamill wants coach Brian Orser to win at Olympics. "The Vancouver Sun 26 Feb. 2010,Canadian Newsstand Complete, ProQuest. Web. 21 Nov. 2010.

Hume, Stephen. "Why sport matters; It's been with us for at least 4,000 years, and -like art -- at some profound level we can't live without it. " The Vancouver Sun 15 Feb. 2010,Canadian Newsstand Complete, ProQuest. Web. 21 Nov. 2010.

Huston, Darren. "The Social Games start with this Olympics. " The Vancouver Sun 18 Feb. 2010,Canadian Newsstand Complete, ProQuest. Web. 21 Nov. 2010.

Hutchinson, Cam. "Fun Games for CTV quite a contrast to CBC production. "The Vancouver Sun 24 Feb. 2010,Canadian Newsstand Complete, ProQuest. Web. 21 Nov. 2010.

Ignatieff, Michael. "With these Games, Canada has made a statement to itself. " The Vancouver Sun 1 March 2010,Canadian Newsstand Complete, ProQuest. Web. 11 Jan. 2011.

Ivanova, Iglika. "A post-Olympic vision is needed for BC. " The Vancouver Sun 1 March 2010,Canadian Newsstand Complete, ProQuest. Web. 11 Jan. 2011.

Jamieson, Jim. "A bittersweet game looms for Canada, Russia; Matchup is always welcome, but it's a shame one team won't get a medal, says goaltending legend Tretiak. " The Vancouver Sun 24 Feb. 2010,Canadian Newsstand Complete, ProQuest. Web. 21 Nov. 2010.

Janisse, Michel. "a perfectly Canadian finish. " The Vancouver Sun 1 March 2010,Canadian Newsstand Complete, ProQuest. Web. 11 Jan. 2011.

Johnson, George. "Canada's medal hopes slim, but interest's high. " The Vancouver Sun 16 Feb. 2010, Canadian Newsstand Complete, ProQuest. Web. 21 Nov. 2010. 
Johnson, George. "Nesbitt heeds advice on way to main event; Korea's Sang-Hwa Lee edges favoured Jenny Wolf of Germany for gold in 500-metre long track. " The Vancouver Sun 17 Feb. 2010,Canadian Newsstand Complete, ProQuest. Web. 21 Nov. 2010.

Johnson, George. "Sometimes gold is not quite perfect enough; Christine Nesbitt struggles to smile after winning 1,000-metres race in less than spectacular fashion, by her own standards anyway. "The Vancouver Sun 19 Feb. 2010,Canadian Newsstand Complete, ProQuest. Web. 21 Nov. 2010.

Kingston, Gary. "An eyelash from the podium; Canada's Eric Guay has finished fourth, fifth and fifth in his three Olympic alpine races. "The Vancouver Sun 20 Feb. 2010,Canadian Newsstand Complete, ProQuest. Web. 11 Jan. 2011.

Kingston, Gary. "Dreams of medals go downhill quickly; Janyk finishes sixth on taxing track, but her Canadian teammates were no match for winner Vonn. " The Vancouver Sun 18 Feb. 2010,Canadian Newsstand Complete, ProQuest. Web. 21 Nov. 2010.

Kingston, Gary. "Injury reports take a bruising; While they don't deny that it hurts, many of Lindsey Vonn's competitors play down the impact of her injury. "The Vancouver Sun 17 Feb. 2010,Canadian Newsstand Complete, ProQuest. Web. 21 Nov. 2010.

Kingston, Gary. "Maria Riesch proves to be tuhe Olympic ber skier; German technical specialist wins slalom for second gold. " The Vancouver Sun 27 Feb. 2010,Canadian Newsstand Complete, ProQuest. Web. 21 Nov. 2010.

Kingston, Gary. "Mind games stand in for training runs; Women keep sharp even when they can't hit the course. " The Vancouver Sun 15 Feb. 2010,Canadian Newsstand Complete, ProQuest. Web. 21 Nov. 2010.

Kingston, Gary. "Murray was special. " The Vancouver Sun 12 Feb. 2010,Canadian Newsstand Complete, ProQuest. Web. 21 Nov. 2010.

Kingston, Gary. "Skiing through injury. " The Vancouver Sun 26 Feb. 2010,Canadian Newsstand Complete, ProQuest. Web. 21 Nov. 2010.

Kingston, Gary. "Takes a lot of nerve to reach ski podium; Throwing caution to the wind will help, but some wily veterans have been waiting for this moment. "The Vancouver Sun 13 Feb. 2010,Canadian Newsstand Complete, ProQuest. Web. 21 Nov. 2010. 
Kingston, Gary. "Canada, Austria ponder Olympic alpine failure; Team Canada downhillers, Wunderteam's men shut out. " The Vancouver Sun 1 March 2010,Canadian Newsstand Complete, ProQuest. Web. 11 Jan. 2011.

Kitts, Colleen. "Swift's solo career showing some kick; NB singer showcases new CD at Olympics. " Here 25 Feb. 2010, Saint John, Fredericton and Moncton edition: Canadian Newsstand Complete, ProQuest. Web. 21 Nov. 2010.

Klein, Seth. "Olympics won't bring lasting economic benefits. "The Vancouver Sun 22 Feb. 2010,Canadian Newsstand Complete, ProQuest. Web. 21 Nov. 2010.

Kuzma, Ben. "Tactics. " The Vancouver Sun 13 Feb. 2010,Canadian Newsstand Complete, ProQuest. Web. 21 Nov. 2010.

Lacombe, Doug. "'Commander in Tweets' sought by U.S. president. " Star - Phoenix 13 Feb. 2010,Canadian Newsstand Complete, ProQuest. Web. 21 Nov. 2010.

Laucius, Joanne. "Quiet arrogance and modesty are an unpredictable mix; For a country that takes pride in its humility, Canadians have a hair-trigger sense of offence. " The Vancouver Sun 27 Feb. 2010,Canadian Newsstand Complete, ProQuest. Web. 21 Nov. 2010.

Lebreton, Gil. "Just about time for a Code Red on that Own the Podium thing, eh? " The Vancouver Sun 20 Feb. 2010,Canadian Newsstand Complete, ProQuest. Web. 21 Nov. 2010.

Lee, Jeff. "COC asks Ottawa for an additional $\$ 22$ million a year; Olympic Committee coaches and support staff will be poached if federal government doesn't cough up more funding." The Vancouver Sun 25 Feb. 2010,Canadian Newsstand Complete, ProQuest. Web. 11 Jan. 2011.

Lee, Jeff. "An early morning visit to the Today show; American hosts dedicated to bringing viewers a slice of life from the Olympics. "The Vancouver Sun 16 Feb. 2010,Canadian Newsstand Complete, ProQuest. Web. 21 Nov. 2010.

Lee, Jeff. "Furlong 'stunned' at level of patriotism; Vanoc CEO expected Canadians to embrace the Olympics, but admits the size of the crowds has been shocking. "The Vancouver Sun 25 Feb. 2010,Canadian Newsstand Complete, ProQuest. Web. 21 Nov. 2010.

Lee, Jeff. "NHL needs the Olympics, Rogge says. " The Vancouver Sun 26 Feb. 2010,Canadian Newsstand Complete, ProQuest. Web. 21 Nov. 2010. 
Lee, Jeff. "Why you don't see Gretzky smiling; The demands for autographs and other favours are virtually endless, and being out in public is hard work. 'I don't know how he keeps it up day after day after day,' his brother says. "The Vancouver Sun 23 Feb. 2010,Canadian Newsstand Complete, ProQuest. Web. 21 Nov. 2010.

Lee, Jeff. "Furlong moved more than a mountain, he moved a country." The Vancouver Sun 1 March 2010,Canadian Newsstand Complete, ProQuest. Web. 11 Jan. 2011.

Lindel, Rebecca. "For Patrick Chan's father, the Olympics are just the beginning. "The Vancouver Sun 16 Feb. 2010,Canadian Newsstand Complete, ProQuest. Web. 21 Nov. 2010.

Lindel, Rebecca. "Police, rescuers scour park for missing actor; Search for Andrew Koenig taken to woods and beaches of Stanley Park, where he liked to stroll. " The Vancouver Sun 24 Feb. 2010,Canadian Newsstand Complete, ProQuest. Web. 21 Nov. 2010.

Little, Lyndon. "New judging backer gives system good spin; Lysacek victory pointed to as vindication. " The Vancouver Sun 20 Feb. 2010,Canadian Newsstand Complete, ProQuest. Web. 21 Nov. 2010.

Little, Lyndon. "U.S. skaters escape from winter to Vancouver; Turin silver medallists are victims of blizzard that has crippled the American East Coast. " The Vancouver Sun 15 Feb. 2010,Canadian Newsstand Complete, ProQuest. Web. 21 Nov. 2010.

Lopresti, Mike. "The 'Miracle on Ice' captivated a nation and still resonates; It's been 30 years since a little American magic at the Lake Placid Olympics turned a group of college kids into hockey legends. "The Vancouver Sun 24 Feb. 2010,Canadian Newsstand Complete, ProQuest. Web. 21 Nov. 2010.

Lopresti, Mike. "TV. " The Vancouver Sun 17 Feb. 2010,Canadian Newsstand Complete, ProQuest. Web. 21 Nov. 2010.

Macfarlane, Lisa. "Hydrogen highway begins in Whistler; Alternative-powered buses help keep the air over Whistler cleaner and reduce the possibility of smog. "The Vancouver Sun 12 Feb. 2010,Canadian Newsstand Complete, ProQuest. Web. 21 Nov. 2010.

Maclntyre, lain. "A life is lost; it begins and ends with us; Canada's pride should not push aside a young man's death on a course powered by bravado." The Vancouver Sun 13 Feb. 2010,Canadian Newsstand Complete, ProQuest. Web. 11 Jan. 2011.

Maclntyre, lain. "Cold War awakes from hibernation; Hosts take successful first step on the Luongo road to hockey gold. "The Vancouver Sun 24 Feb. 2010,Canadian Newsstand Complete, ProQuest. Web. 21 Nov. 2010. 
Maclntyre, lain. "Morrow grinding out the goals; Team Canada role player continues his scoring binge in Canada's semifinal win over Slovakia. "The Vancouver Sun 27 Feb. 2010,Canadian Newsstand Complete, ProQuest. Web. 21 Nov. 2010.

Maclntyre, lain. "Sid ends our Fright Night with blood, guts and goal; Vancouver gets a look at what Crosby can do. "The Vancouver Sun 19 Feb. 2010,Canadian Newsstand Complete, ProQuest. Web. 21 Nov. 2010.

Maclntyre, lain. "Stastny family reflects U.S. team's togetherness; Talented Canadianborn Yankee with Czech bloodlines loves playing in 'hockey nation'. " The Vancouver Sun 27 Feb. 2010,Canadian Newsstand Complete, ProQuest. Web. 21 Nov. 2010.

Maclntyre, lain. "Stastny family reflects U.S. team's togetherness; Talented Canadianborn Yankee with Slovak bloodlines loves playing in 'hockey nation'. " The Vancouver Sun 27 Feb. 2010,Canadian Newsstand Complete, ProQuest. Web. 21 Nov. 2010.

Mackie, John. "'Unstable Sable' makes coast-to-coast odyssey; Twin brothers and friends drive from Halifax to the Vancouver Olympics on a whim and a prayer. "The Vancouver Sun 27 Feb. 2010,Canadian Newsstand Complete, ProQuest. Web. 21 Nov. 2010.

Mackie, John. "From Minsk with love; Belarus Olympic fans make up for their country's small size with intense passion. "The Vancouver Sun 20 Feb. 2010,Canadian Newsstand Complete, ProQuest. Web. 21 Nov. 2010.

Mackie, John. "Olympics usher in a big new age of advertising; Building-sized banners and huge hockey masks and Team Canada jerseys help super-size the fun. "The Vancouver Sun 23 Feb. 2010,Canadian Newsstand Complete, ProQuest. Web. 21 Nov. 2010.

Mackie, John. "Southern visitor wears the Stars and Stripes and spreads the word. "The Vancouver Sun 17 Feb. 2010,Canadian Newsstand Complete, ProQuest. Web. 21 Nov. 2010.

Mackie, John. "Takin' it to the (downtown) streets; For many people the Olympic experience is about crowds, street life and an abundance of arts and culture. "The Vancouver Sun 27 Feb. 2010,Canadian Newsstand Complete, ProQuest. Web. 21 Nov. 2010.

MacPherson, Maudie. "Seniors News: Grand Time to be Canadian! " The Aldergrove Star 17 Feb. 2010,Canadian Newsstand Complete, ProQuest. Web. 21 Nov. 2010. 
Marchand, Francois. "Tune in, pump up, get psyched; Music makes a difference to athletes gearing up for -- and calming down after -- a key performance. " The Vancouver Sun 20 Feb. 2010,Canadian Newsstand Complete, ProQuest. Web. 21 Nov. 2010.

Mason, Gary. "A golden end to Games that altered nation." The Vancouver Sun 1 March 2010,Canadian Newsstand Complete, ProQuest. Web. 11 Jan. 2011.

McKnight, Peter. "Banning performance-enhancing drugs neither ensures fair play nor protects athletes' health. "The Vancouver Sun 16 Feb. 2010,Canadian Newsstand Complete, ProQuest. Web. 21 Nov. 2010.

McKnight, Peter. "Politics and the Olympic religion; Introduced as a way of achieving world peace, the Games have never been solely about sport. "The Vancouver Sun 12 Feb. 2010,Canadian Newsstand Complete, ProQuest. Web. 21 Nov. 2010.

McMartin, Pete. "More than just a good ol' hockey game; Canadians know that pitting Team Canada against Team USA in the Olympics is the best game you can name. " The Vancouver Sun 22 Feb. 2010,Canadian Newsstand Complete, ProQuest. Web. 21 Nov. 2010.

McMartin, Pete. "Trabants, torches and transit heroes; And other miscellaneous things observed, received and surmised at the 2010 Winter Games. "The Vancouver Sun 19 Feb. 2010,Canadian Newsstand Complete, ProQuest. Web. 21 Nov. 2010.

McMartin, Pete. "Ceremony captures a fresh image of Canada; Michael Buble's campy rendition of The Maple Leaf Forever a memorable moment in production by a country now more willing to laugh at itself. " The Vancouver Sun 1 March 2010,Canadian Newsstand Complete, ProQuest. Web. 11 Jan. 2011.

McRanor, Graeme. "Feist never really left, but she's back, in case you missed her; Show at the Orpheum tonight isn't the first time she's performed at the Olympics. "The Vancouver Sun 17 Feb. 2010,Canadian Newsstand Complete, ProQuest. Web. 21 Nov. 2010.

McRanor, Graeme. "Hip hop: 'People's anthem' hits Olympics in Vancouver. "The Vancouver Sun 25 Feb. 2010,Canadian Newsstand Complete, ProQuest. Web. 21 Nov. 2010.

McRanor, Graeme. "Wintersleep bright-eyed, bushy-tailed for Olympics; Montrealbased indie band puts on five free performances in Vancouver, Whistler. "The Vancouver Sun 24 Feb. 2010,Canadian Newsstand Complete, ProQuest. Web. 21 Nov. 2010. 
Michaelis, Vicki. "Drive to rack up medals. " The Vancouver Sun 20 Feb. 2010,Canadian Newsstand Complete, ProQuest. Web. 21 Nov. 2010.

Mickleburgh, Rod. "Cool, detached, self-satisfied Vancouver gains momentum." The Vancouver Sun 25 Feb. 2010,Canadian Newsstand Complete, ProQuest. Web. 11 Jan. 2011.

Mickleburgh, Rod. "Canada swaggers to centre stage at BC Place." The Vancouver Sun 1 March 2010,Canadian Newsstand Complete, ProQuest. Web. 11 Jan. 2011.

Monk, Katherine. "Olympics unheralded on the silver screen; Is Leni Riefenstahl's Olympia, which glorified Hitler's 1936 Berlin Games, to blame? " The Vancouver Sun 16 Feb. 2010,Canadian Newsstand Complete, ProQuest. Web. 21 Nov. 2010.

Morgan, Keith. "Strategies to get around; Driving in the city during the Olympics need not be a stressful experience. " The Vancouver Sun 19 Feb. 2010,Canadian Newsstand Complete, ProQuest. Web. 21 Nov. 2010.

Morton, Brian. "Biathlete's family travels from far and wide to cheer her on; The home away from home for visitors, who have come from as far away as Hawaii, includes a 10-metre recreational vehicle. " The Vancouver Sun 22 Feb. 2010,Canadian Newsstand Complete, ProQuest. Web. 21 Nov. 2010.

Morton, Brian. "Norwegian bakers cook up a healthy Squamish loaf; Specialty breads made daily at local bakery for 300 Olympic athletes and support staff. " The Vancouver Sun 16 Feb. 2010,Canadian Newsstand Complete, ProQuest. Web. 21 Nov. 2010.

Mulgrew, lan. "Four Canadian icons officially open Games: LeMay Doan, Nash Greene Rain, Gretsky light the flame. "The Vancouver Sun 13 Feb. 2010,Canadian Newsstand Complete, ProQuest. Web. 11 Jan. 2011.

Mulgrew, lan. "Jon Montgomery to the rescue; Skeleton racer's gold medal lifts sagging spirits on disappointing day for Canada. "The Vancouver Sun 20 Feb. 2010,Canadian Newsstand Complete, ProQuest. Web. 11 Jan. 2011.

Mulgrew, lan. "Stars and stripes dominate the podium; The day belonged to the Americans, but Canada's athletes refused to lay down and die. "The Vancouver Sun 18 Feb. 2010,Canadian Newsstand Complete, ProQuest. Web. 21 Nov. 2010.

Olivier, Cassidy. "Relay: Mr. Lonely gets some company; Lone runner joined by teammates arriving from Europe. "The Vancouver Sun 26 Feb. 2010,Canadian Newsstand Complete, ProQuest. Web. 21 Nov. 2010. 
Pap, Elliott. "Flash has too much Finnish for lowly Belarus; Selanne continues to shine in his fifth Olympics as Finland skates circles around overmatched opponents. "The Vancouver Sun 18 Feb. 2010,Canadian Newsstand Complete, ProQuest. Web. 21 Nov. 2010.

Pap, Elliott. "Forsberg wants a final shot at gold, not a return to NHL; Swedish teammates insist former NHL star can still skate and has magic in his stick, although he didn't dazzle in win against Germany. " The Vancouver Sun 19 Feb. 2010,Canadian Newsstand Complete, ProQuest. Web. 21 Nov. 2010.

Pap, Elliott. "Russians reduced to rubble in a hurry by 'Energizer bunnies'; Backup netminder blames lack of passion and focus for playoff whipping, but refuses to point fingers at players or coaches. "The Vancouver Sun 25 Feb. 2010,Canadian Newsstand Complete, ProQuest. Web. 21 Nov. 2010.

Pap, Elliott. "Swiss fall, now face Canada; Hiller says his team needs to be perfect. " The Vancouver Sun 17 Feb. 2010,Canadian Newsstand Complete, ProQuest. Web. 21 Nov. 2010.

Parry, Malcolm. "Shabby Vogue Theatre gets a new life; Granville Street venue spruced up by \$3-million renovation, offers live performances. "The Vancouver Sun 18 Feb. 2010,Canadian Newsstand Complete, ProQuest. Web. 21 Nov. 2010.

Pemberton, Kim. "Aboriginal business association seekd Olympic godl; Fove high-profile venues at the Games highlight native cultural tourist attractions throughout BC. " The Vancouver Sun 13 Feb. 2010,Canadian Newsstand Complete, ProQuest. Web. 11 Jan. 2011.

Pemberton, Kim. "Aboriginal chefs have sights set on Culinary Olympics in Germany; Team's training includes preparing gourmet feast during Games. "The Vancouver Sun 19 Feb. 2010,Canadian Newsstand Complete, ProQuest. Web. 21 Nov. 2010.

Pemberton, Kim. "Off-reserve aboriginals say they've been left out of Games; Umbrella organization representing $\mathbf{2 5}$ groups claims it has not received any funding from Vanoc. "The Vancouver Sun 24 Feb. 2010,Canadian Newsstand Complete, ProQuest. Web. 21 Nov. 2010.

Pemberton, Kim. "Olympics have returned aboriginals to rightful place, says leader. " The Vancouver Sun 17 Feb. 2010,Canadian Newsstand Complete, ProQuest. Web. 21 Nov. 2010.

Penner, Derrick. "Australians use 'power of schmooze' to bolster trade ties. "The Vancouver Sun 27 Feb. 2010,Canadian Newsstand Complete, ProQuest. Web. 21 Nov. 2010. 
Pynn, Larry. "Emergency plans can accommodate thousands if Olympics hit by disaster; Province and municipalities team up to stockpile supply of cots, blankets and toiletries. " The Vancouver Sun 12 Feb. 2010,Canadian Newsstand Complete, ProQuest. Web. 21 Nov. 2010.

Pynn, Larry. "Cop cut from Olympic team for drinking." The Vancouver Sun 13 Feb. 2010,Canadian Newsstand Complete, ProQuest. Web. 1 Jan. 2011.

Pynn, Larry. "Olympics will use enough electricity to power small city; Highest peak oneday usage has been at Whistler Olympic Park, site of biathlon, cross-country, ski jump and Nordic combined. "The Vancouver Sun 17 Feb. 2010,Canadian Newsstand Complete, ProQuest. Web. 21 Nov. 2010.

Pynn, Larry. "Record crowd expected at YVR on Monday; A plan is in place to accommodate as many as 39,000 passengers leaving town. " The Vancouver Sun 26 Feb. 2010,Canadian Newsstand Complete, ProQuest. Web. 21 Nov. 2010.

Rachar, Lee. "So who has missed the point? " Burnaby Now 20 Feb. 2010,Canadian Newsstand Complete, ProQuest. Web. 21 Nov. 2010.

Reid, Pat. "Olympic Low Note." The Vancouver Sun 25 Feb. 2010,Canadian Newsstand Complete, ProQuest. Web. 1 Jan. 2011.

Sasvari, Joanne. "Drinking in the Olympics; Top local bartenders square off against international stars in black box cocktail competition this weekend. " The Vancouver Sun 17 Feb. 2010,Canadian Newsstand Complete, ProQuest. Web. 21 Nov. 2010.

Scanlan, David. "'Olympics aversion' fails to slow Whistler; The resort will fare far better than expected this year, CEO says. " The Vancouver Sun 23 Feb. 2010,Canadian Newsstand Complete, ProQuest. Web. 21 Nov. 2010.

Scanlan, Wayne. "Boiling Canadians burn shocked Russians; Bulldog line renders Ovechkin useless, while hungry offence rolls over rivals like a tsunami. "The Vancouver Sun 25 Feb. 2010,Canadian Newsstand Complete, ProQuest. Web. 21 Nov. 2010.

Scanlan, Wayne. "Clashes of the titans. " The Vancouver Sun 20 Feb. 2010,Canadian Newsstand Complete, ProQuest. Web. 21 Nov. 2010.

Scanlan, Wayne. "Hero. " The Vancouver Sun 18 Feb. 2010,Canadian Newsstand Complete, ProQuest. Web. 21 Nov. 2010.

Scanlan, Wayne. "Yzerman still packs a big slapshot; Canada GM fires back at questions about Olympic-sized pressure. " The Vancouver Sun 15 Feb. 2010,Canadian Newsstand Complete, ProQuest. Web. 21 Nov. 2010. 
Shaw, Gilian. "Death porn or just sharing the latest news? Traditional and social media air video of fatal accident from Whistler luge track. " The Vancouver Sun 13 Feb. 2010,Canadian Newsstand Complete, ProQuest. Web. 11 Jan. 2011.

Shaw, Gilian. "B.C. wineries savour chance to showcase product to the world; 'It is pretty exciting to be part of Olympics,' Osoyoos winemaker says. " The Vancouver Sun 23 Feb. 2010,Canadian Newsstand Complete, ProQuest. Web. 21 Nov. 2010.

Shaw, Gillian. "A navigation system for the Olympics. " The Vancouver Sun 20 Feb. 2010,Canadian Newsstand Complete, ProQuest. Web. 21 Nov. 2010.

Shaw, Gillian. "Bloggers abuzz over Olympics; Games have become a top Twitter topic. " The Vancouver Sun 19 Feb. 2010,Canadian Newsstand Complete, ProQuest. Web. 21 Nov. 2010.

Shaw, Gillian. "Decent ratings for NBC make headlines for U.S. media outlets; Viewership up sharply from 2006 Winter Games in Turin. " The Vancouver Sun 16 Feb. 2010,Canadian Newsstand Complete, ProQuest. Web. 21 Nov. 2010.

Shaw, Gillian. "Whistler strives for sustainability; The resort municipality grapples with the 'double-edged sword' of tourism. " The Vancouver Sun 25 Feb. 2010,Canadian Newsstand Complete, ProQuest. Web. 21 Nov. 2010.

Sinoski, Kelly. "Impark ups parking rat to $\$ 95$ a day at two lots; The hike is to discourage day-long users, company says. " The Vancouver Sun 13 Feb. 2010,Canadian Newsstand Complete, ProQuest. Web. 11 Jan. 2011.

Sinoski, Kelly. "'Hanging Judge' handing out pins, not sentences; B.C.'s infamous 19thcentury judge turns up for the Olympics, at Robson Square. " The Vancouver Sun 17 Feb. 2010,Canadian Newsstand Complete, ProQuest. Web. 21 Nov. 2010.

Sinoski, Kelly. "A finale full of fun and innovation; Celebrity performers ready for the end game of Vancouver's 2010 Olympics. " The Vancouver Sun 27 Feb. 2010,Canadian Newsstand Complete, ProQuest. Web. 21 Nov. 2010.

Sinoski, Kelly. "Games fever draws people from far and wide; Thousands come from across Canada, south of the border and Europe to don a Smurf suit and help make the Olympics a success. "The Vancouver Sun 19 Feb. 2010,Canadian Newsstand Complete, ProQuest. Web. 21 Nov. 2010.

Sinoski, Kelly. "LiveCity Yaletown concerts resume after accident; New barrier installed after old one collapses during Tuesday night performance. " The Vancouver Sun 18 Feb. 2010,Canadian Newsstand Complete, ProQuest. Web. 21 Nov. 2010. 
Sinoski, Kelly. "Native artist brightens up Team Netherlands; Snowboarders honoured by City Hall, patriotic poet to perform at bookstore. " The Vancouver Sun 25 Feb. 2010,Canadian Newsstand Complete, ProQuest. Web. 21 Nov. 2010.

Sinoski, Kelly. "No tickets? No problem; Free concerts, events and entertainment dot the landscape during the 2010 Olympics. "The Vancouver Sun 12 Feb. 2010,Canadian Newsstand Complete, ProQuest. Web. 21 Nov. 2010.

Sinoski, Kelly. "Sally Ann to the rescue with cocoa to go; Volunteers serve hot drinks to transit crowds during the Games. "The Vancouver Sun 26 Feb. 2010,Canadian Newsstand Complete, ProQuest. Web. 21 Nov. 2010.

Slater, Jim. "Grief won't stop Burke's Olympic moment. " The Vancouver Sun 15 Feb. 2010,Canadian Newsstand Complete, ProQuest. Web. 21 Nov. 2010.

Soshnick, Scott. "Comment. " The Vancouver Sun 27 Feb. 2010,Canadian Newsstand Complete, ProQuest. Web. 21 Nov. 2010.

Stainsby, Mia. "Aboriginal House chef is an Olympic medallist; The Culinary Olympics, that is. Now Arnold Olson is feeding up to 13,000 a day and hoping to inspire the next generation of aboriginal cooks. "The Vancouver Sun 19 Feb. 2010,Canadian Newsstand Complete, ProQuest. Web. 21 Nov. 2010.

Stainsby, Mia. "Three to Try. " The Vancouver Sun 12 Feb. 2010,Canadian Newsstand Complete, ProQuest. Web. 21 Nov. 2010.

Stainsby, Mia. "Three To Try. "The Vancouver Sun 19 Feb. 2010,Canadian Newsstand Complete, ProQuest. Web. 21 Nov. 2010.

Stainsby, Mia. "Three To Try. " The Vancouver Sun 27 Feb. 2010,Canadian Newsstand Complete, ProQuest. Web. 21 Nov. 2010.

Stainsby, Mia. "Today Show feeds interest in local chefs, restaurants. "The Vancouver Sun 20 Feb. 2010,Canadian Newsstand Complete, ProQuest. Web. 21 Nov. 2010.

Staple, Arthur. "'Underdog' team faces new challenge as favourites; With its upset of Canada and the hottest goalie at the Games in Ryan Miller, the U.S. must beware of believing the hype. "The Vancouver Sun 24 Feb. 2010,Canadian Newsstand Complete, ProQuest. Web. 21 Nov. 2010.

Stefenhagen, Janet. "UBC students spend Olympic 'holiday' in inner-city schools; University and software workers team up to mentor kids and gain experience. " The Vancouver Sun 26 Feb. 2010,Canadian Newsstand Complete, ProQuest. Web. 21 Nov. 2010. 
Strachan, Alex. "NBC's Games commentators praise the Great White North. " The Vancouver Sun 15 Feb. 2010,Canadian Newsstand Complete, ProQuest. Web. 21 Nov. 2010.

Strachan, Alex. "Patriotic Canadian composes song for Colbert. " The Vancouver Sun 17 Feb. 2010,Canadian Newsstand Complete, ProQuest. Web. 21 Nov. 2010.

Strachan, Alex. "Putting TV on the podium; A look at the highs and lows in television's coverage of the Olympic Games. "The Vancouver Sun 26 Feb. 2010,Canadian Newsstand Complete, ProQuest. Web. 21 Nov. 2010.

Taber, Jane. "Tories push patriotism - and possibly votes." The Vancouver Sun 20 Feb. 2010,Canadian Newsstand Complete, ProQuest. Web. 11 Jan. 2011.

Thomas, Gregory. "Tiger Woods, Olympics keep volume light. " The Vancouver Sun 20 Feb. 2010,Canadian Newsstand Complete, ProQuest. Web. 21 Nov. 2010.

Todd, Douglas. "Adding thought to feelings about Olympics; Consider an authentic response, whether you are for or against the 2010 Games. " The Vancouver Sun 17 Feb. 2010,Canadian Newsstand Complete, ProQuest. Web. 21 Nov. 2010.

Todd, Douglas. "So, what exactly are we supposed to 'believe' in?; Many are asking us to do it, and it might help a bit, but belief won't be the sole factor in any kind of success. "The Vancouver Sun 25 Feb. 2010,Canadian Newsstand Complete, ProQuest. Web. 21 Nov. 2010.

Traikos, Michael; With files from Jeff Lee, and Vancouver Sun. "Vanoc refunding tickets for Cypress event; Weather, transportation and even food services troubles plague venue and now standing-room tickets have been cancelled. "The Vancouver Sun 15 Feb. 2010,Canadian Newsstand Complete, ProQuest. Web. 21 Nov. 2010.

Traikos, Michael. "Back on track. " The Vancouver Sun 17 Feb. 2010,Canadian Newsstand Complete, ProQuest. Web. 21 Nov. 2010.

Traikos, Michael. "Hamelin's dream of being an Olympic hero now a done deal; Quebec speedskater's evening ends with hugs, kisses, three medals, tearful teammates and special memories to last a lifetime. " The Vancouver Sun 27 Feb. 2010,Canadian Newsstand Complete, ProQuest. Web. 21 Nov. 2010.

Traikos, Michael. "Skaters push themselves -- and teammates -- to win; Canadian women usually perform well in rough-and-tumble 3,000-metre speed-skating relay, and coaches are counting on a solid effort. " The Vancouver Sun 24 Feb. 2010,Canadian Newsstand Complete, ProQuest. Web. 21 Nov. 2010. 
Traikos, Michael. "Speedskater Hamelin faces his foes on short track and hopes to lead team to podiums; With a recent world record in the 1,000 meter under his spandex the 2006 Olympic medallist is hoping to win more. " The Vancouver Sun 12 Feb. 2010,Canadian Newsstand Complete, ProQuest. Web. 21 Nov. 2010.

Traikos, Michael. "Time running out for medal-favourite Charles Hamelin. " The Vancouver Sun 22 Feb. 2010,Canadian Newsstand Complete, ProQuest. Web. 21 Nov. 2010.

Traikos, Michael. "Seeing-eye pass from 'Iggy' all Sid needed to ice the game; "He was yelling. He was yelling pretty urgently," Iginla says of Crosby's call for the pass that led to the winning goal. " The Vancouver Sun 1 March 2010,Canadian Newsstand Complete, ProQuest. Web. 11 Jan. 2011.

Vanstone, Rob. "Austrian 'Eagles' soar to Olympic record at Whistler. "The Vancouver Sun 23 Feb. 2010,Canadian Newsstand Complete, ProQuest. Web. 21 Nov. 2010.

Vanstone, Rob. "Doubles luge. " The Vancouver Sun 17 Feb. 2010,Canadian Newsstand Complete, ProQuest. Web. 21 Nov. 2010.

Vanstone, Rob. "Officials hope new ski jump facility will boost interest in sport; Governing body must show facility can generate enough revenue to offset costs. " The Vancouver Sun 25 Feb. 2010,Canadian Newsstand Complete, ProQuest. Web. 21 Nov. 2010.

Vanstone, Rob. "Youth. " The Vancouver Sun 22 Feb. 2010,Canadian Newsstand Complete, ProQuest. Web. 21 Nov. 2010.

Vignal, Patrick. "Downhill racer: Janka 'clearly' the favourite. " The Vancouver Sun 12 Feb. 2010,Canadian Newsstand Complete, ProQuest. Web. 21 Nov. 2010.

Waldie, Paul. "Vindication for Own the Podium" The Vancouver Sun 1 March 2010,Canadian Newsstand Complete, ProQuest. Web. 11 Jan. 2011.

Walker, Ian. "Star's top challenger watches Olympics from brain-injury facility." The Vancouver Sun 18 Feb. 2010,Canadian Newsstand Complete, ProQuest. Web. 21 Nov. 2010.

Ward, Bruce. "Dube, Wotherspoon win the Hair Olympics; Celebrity hair awards honour athletes and actors with podium-worthy locks. "The Vancouver Sun 27 Feb. 2010,Canadian Newsstand Complete, ProQuest. Web. 21 Nov. 2010.

Ward, Doug. "'Activist' councillor feels little solidarity with protesters; 'We don't have homelessness because we have the Olympics,' Geoff Meggs says. "The Vancouver Sun 15 Feb. 2010,Canadian Newsstand Complete, ProQuest. Web. 21 Nov. 2010. 
Ward, Doug. "A great O Canada day; Medals in speed skating and bobsleigh, and a rousing men's hockey win over Russia. "The Vancouver Sun 25 Feb. 2010,Canadian Newsstand Complete, ProQuest. Web. 21 Nov. 2010.

Ward, Doug. "Olympics find many exuberant fans in shelters; Support for athletes found, despite misgivings about cost of Games. " The Vancouver Sun 23 Feb. 2010,Canadian Newsstand Complete, ProQuest. Web. 21 Nov. 2010.

Ward, Doug. "Vancouver residents warm to Olympics. " The Vancouver Sun 24 Feb. 2010,Canadian Newsstand Complete, ProQuest. Web. 21 Nov. 2010.

Weber, Marc. "Americans shut out Russia; Loss reflects lack of support for team: star. " The Vancouver Sun 17 Feb. 2010,Canadian Newsstand Complete, ProQuest. Web. 21 Nov. 2010.

Weeks, Bob. "Olympic Centre rocks with true patriotic love. " The Vancouver Sun 1 March 2010,Canadian Newsstand Complete, ProQuest. Web. 11 Jan. 2011.

Weir, Tom; and Dodd, Mike. "Relationship building 101; American medallists have put their personal problems on the back burner in pursuit of Olympic glory. "The Vancouver Sun 19 Feb. 2010,Canadian Newsstand Complete, ProQuest. Web. 21 Nov. 2010.

Whicker, Mark. "For love or money?; NHL and IOC officials debate the 2014 Games in Sochi and the Winter Olympics' effect on the NHL season. "The Vancouver Sun 22 Feb. 2010,Canadian Newsstand Complete, ProQuest. Web. 21 Nov. 2010.

Wolfe, Cory. "Anderson aims to release his 'inner bear'; If Olympics prove to be his last hurrah, Canadian veteran wants to enjoy the golden handshake. "The Vancouver Sun 13 Feb. 2010,Canadian Newsstand Complete, ProQuest. Web. 21 Nov. 2010.

Wolfe, Cory. "Olympics Q\&A: Keeping ahead of the curve. " The Vancouver Sun 23 Feb. 2010,Canadian Newsstand Complete, ProQuest. Web. 21 Nov. 2010.

Wolfe, Cory. "Wardrobe malfunctions as old as the Olympics; From see-through figureskating costumes to barely there bodices, the potential for unwanted high-profile exposure is huge. "The Vancouver Sun 24 Feb. 2010,Canadian Newsstand Complete, ProQuest. Web. 21 Nov. 2010.

Wolfe, Cory. "Anderson emerges from fog to grab gold; Veteran rides roller-coaster of past Olympic disappointments to win parallel giant slalom title . "The Vancouver Sun 1 March 2010,Canadian Newsstand Complete, ProQuest. Web. 11 Jan. 2011.

Woo, Andrea. "Why no one's in a bad mood during the Winter Games; Patriotism runs rampant through the streets of Vancouver and Whistler. "The Vancouver Sun 22 Feb. 2010,Canadian Newsstand Complete, ProQuest. Web. 21 Nov. 2010. 
Youngman, Randy. "Curlers make up for Canadian hockey hiccup, but NBC still all wet for delaying puck action. " The Vancouver Sun 25 Feb. 2010,Canadian Newsstand Complete, ProQuest. Web. 21 Nov. 2010.

Zacharias, Yvonne. "From tragedy comes compassion; Co-workers help RCMP officer who lost family and friends in the Haitian earthquake. " The Vancouver Sun 23 Feb. 2010,Canadian Newsstand Complete, ProQuest. Web. 21 Nov. 2010.

Zacharias, Yvonne. "Haitian-Canadian Mountie bears flag with pride; RCMP officer who lost family members in earthquake carries Maple Leaf at opening and closing ceremonies. " The Vancouver Sun 23 Feb. 2010,Canadian Newsstand Complete, ProQuest. Web. 21 Nov. 2010.

Zacharias, Yvonne. "Haitian-Canadian Mountie bears flag with pride; RCMP officer who lost family members in earthquake takes part in opening and closing ceremonies. " The Vancouver Sun 23 Feb. 2010, Canadian Newsstand Complete, ProQuest. Web. 21 Nov. 2010.

Zacharias, Yvonne. "Kids revel in mini-version of Olympic hockey; 12 teams representing those in the real-life men's tournament face off on Grouse Mountain and come away with much the same results. " The Vancouver Sun 19 Feb. 2010,Canadian Newsstand Complete, ProQuest. Web. 21 Nov. 2010.

Zacharias, Yvonne. "Vive le Vancouver!; Place de la Francophonie showcases Canada's two oficial languages and cultures with style. "The Vancouver Sun 17 Feb. 2010,Canadian Newsstand Complete, ProQuest. Web. 21 Nov. 2010.

Zacharias, Yvonne. "What to expect if you marry an elite athlete; One of Canada's top skeleton racers and his wife hope to help others by sharing their struggles in a new book. " The Vancouver Sun 23 Feb. 2010, Canadian Newsstand Complete, ProQuest. Web. 21 Nov. 2010.

Ziemer, Brad. "Fans wild about Kesler, but Canuck not crazy about Wild; U.S.-born forward takes exception to Boogaard's blind-side hit. " The Vancouver Sun 15 Feb. 2010,Canadian Newsstand Complete, ProQuest. Web. 21 Nov. 2010.

Ziemer, Brad. "Hockey players love the city's atmosphere, intensity, fans; Athletes are puzzled by negative international press; they talk about 'how beautiful it is and what a great Olympics it is,' Henrik Sedin says. " The Vancouver Sun 20 Feb. 2010,Canadian Newsstand Complete, ProQuest. Web. 21 Nov. 2010.

Ziemer, Brad. "Miller crowned king of the hill; American finally collects elusive Olympic gold in super combined. "The Vancouver Sun 22 Feb. 2010,Canadian Newsstand Complete, ProQuest. Web. 21 Nov. 2010. 